IZA DP No. 6258

The Labor Market Effects of Immigration and Emigration in OECD Countries

Frédéric Docquier

Çağlar Özden

Giovanni Peri

December 2011 


\title{
The Labor Market Effects of Immigration and Emigration in OECD Countries
}

\author{
Frédéric Docquier \\ FNRS, IRES, Université Catholique de Louvain \\ and IZA \\ Çağlar Özden \\ World Bank \\ and IZA \\ Giovanni Peri \\ University of California, Davis \\ and IZA
}

Discussion Paper No. 6258

December 2011

\author{
IZA \\ P.O. Box 7240 \\ 53072 Bonn \\ Germany \\ Phone: +49-228-3894-0 \\ Fax: +49-228-3894-180 \\ E-mail: iza@iza.org
}

\begin{abstract}
Any opinions expressed here are those of the author(s) and not those of IZA. Research published in this series may include views on policy, but the institute itself takes no institutional policy positions.

The Institute for the Study of Labor (IZA) in Bonn is a local and virtual international research center and a place of communication between science, politics and business. IZA is an independent nonprofit organization supported by Deutsche Post Foundation. The center is associated with the University of Bonn and offers a stimulating research environment through its international network, workshops and conferences, data service, project support, research visits and doctoral program. IZA engages in (i) original and internationally competitive research in all fields of labor economics, (ii) development of policy concepts, and (iii) dissemination of research results and concepts to the interested public.
\end{abstract}

IZA Discussion Papers often represent preliminary work and are circulated to encourage discussion. Citation of such a paper should account for its provisional character. A revised version may be available directly from the author. 


\section{ABSTRACT \\ The Labor Market Effects of Immigration and Emigration in OECD Countries}

In this paper, we simulate the labor market effects of net immigration and emigration during the 1990's in all OECD countries. To accomplish this, we are the first to employ a comprehensive database of migrant stocks, grouped by education level and country of origin/destination, for the years 1990 and 2000. Due to the much higher international mobility of college graduates, relative to all other individuals, we find that net migration flows are college-intensive, relative to the population of non-migrants. Using the consensus aggregate model of labor demand and supply we simulate the long-run employment and wage effects of immigration and emigration. We use a range of parameter values spanning most of the estimates in the literature. In all cases we find that immigration had a positive effect on the wage of less educated natives. It also increased or left the average native wages unchanged and had a positive or no effect on native employment. To the contrary, emigration had a negative effect on the wage of less educated native workers and it contributed to increase within country inequality in all OECD countries. These results still hold true when we correct for the estimates of undocumented immigrants, for the skill-downgrading of immigrants, when we focus on immigration from non-OECD countries, and when we consider preliminary measures of more recent immigration flows for the period 2000-2007.

JEL Classification: F22, J61, J31

Keywords: immigration and emigration, complementarity, schooling externalities, average wage, wage inequality

Corresponding author:

Giovanni Peri

Department of Economics

University of California Davis

One Shields Avenue

Davis, CA 95616-8578

USA

E-mail: gperi@ucdavis.edu

\footnotetext{
* This article was funded by the project "Brain drain, return migration and South-South migration: impact on labor markets and human capital" supported by the Austrian, German, Korean, and Norwegian governments through the Multi-donor Trust Fund on Labor Markets, Job Creation, and Economic Growth administered by the World Bank's Social Protection and Labor unit. The first author also acknowledges financial support from the Belgian French-speaking Community (convention ARC 09/14-019 on "Geographical Mobility of Factors"). We thank Massimo Anelli, Francesco D'Amuri, Paul Gaggl, Francesc Ortega and participants to seminars at Bocconi University, the OECD, the World Bank, Universitat Autonoma de Barcelona, Copenhagen Business School, University of Helsinki, LEMNA-Nantes, IZA-World Bank conference in Mexico for valuable comments and suggestions. The findings, conclusions and views expressed are entirely those of the authors and should not be attributed to the World Bank, its executive directors or the countries they represent.
} 


\section{Introduction}

Immigration rates in OECD countries are larger than in the rest of the world and they increased significantly in the last 20 years. As of 2000 , about $7.7 \%$ of the adult residents in OECD countries were born in another country, versus only $2.9 \%$ in the average world country (Freeman, 2006). Since then, the number of foreign-born individuals has further increased. In 2009 about $10 \%$ of the OECD resident population was estimated to be foreign-born ${ }^{1}$. The common representation of migration flows portrays a multitude of uneducated individuals, coming from poor countries, trying to gain access to the labor markets and welfare systems of rich countries. This phenomenon, the simplistic view continues to emphasize, contributes to depress wages and it produces job losses for the less educated natives, a group of workers that has under-performed in the labor markets during the last 20 years. The available data and recent analysis (e.g. Docquier and Marfouk, 2006; Grogger and Hanson, 2011), however, are uncovering a different picture of international migrants. First, a large part of the mobility to OECD countries is from other OECD countries (about $4 \%$ of the $7.7 \%$ foreign-born residents of OECD countries in 2000 were from another OECD country). Second, the share of college educated individuals among immigrants is usually larger than the share of college educated workers among natives within the receiving country. In some OECD countries the percentage of college educated workers among immigrants is much larger than among natives (up to 4-5 times).

Our paper documents these features by using a new database that combines original Census data for 76 receiving countries in 2000 and 61 receiving countries in 1990. We use this dataset to measure (or estimate in the case of the missing host countries) bilateral net immigration and emigration flows of all OECD countries in the 1990's. The data distinguish between college-educated and non college-educated migrants, and we also differentiate net flows for each bilateral relation between each OECD country and any other country in the world. These data are new and they are described in detail in Docquier et al. (2010). This paper is the first that uses this data source in order to analyze the impact of migrants. This constitutes a substantial improvement over Docquier and Marfouk (2006) and Docquier et al. (2009), especially in the construction of net emigration data from OECD countries because our data include more than double the number of receiving countries.

Using these data and aggregate models of the national economies and labor markets we simulate the employment and wage effects of immigration and emigration on non-moving nationals of each OECD country. We use an aggregate production-function based model, which has become popular in the labor literature analyzing the national effects of immigration (Borjas 2003; D'Amuri et al., 2010; Ottaviano and Peri, forthcoming, Manacorda et al., forthcoming). Macroeconomic studies studying growth, productivity and the skill premium in the US and other countries have also used a similar framework (e.g. Acemoglu and Zilibotti 2001, Caselli and Coleman 2006, Card and Lemieux 2001, Goldin and Katz 2008). This basic framework enables us to derive a labor demand by skill group and we add a simple labor supply decision that generates an aggregate supply curve for each skill group.

The facts about migration mentioned above have clear implications on the potential effects of immigration and emigration. First, as OECD countries are important sources as

\footnotetext{
${ }^{1}$ These figures are from OECD (2011).
} 
well as destinations for many of the recent world migrants, we need to analyze the potential labor market effects of both flows. Should OECD countries be concerned with the domestic labor market effects of either of them? Second, if migrants have a large share of college graduates, immigration can actually help wages and employment of less educated (through complementarity) and possibly also average wages (through human capital externalities). To the contrary, emigration may hurt them. Immigrants in Barcelona or Athens are more visible to the European public eye than the Spanish or Greek engineers in Silicon Valley, but are they more harmful to the labor market options of Spanish and Greek workers with low education? While there are many studies on the labor market effects of immigration on individual OECD countries there is only a handful of studies on the labor market effects of emigration. This asymmetric view may lead to misconceptions of the economic effects of migration. The goal of this paper is to assess the impact of global labor movements in the 1990 's on the wages of those who did not migrate.

The existing estimates of the labor market effects of immigrants are often seen as differentiated or even as conflicting with each other ${ }^{2}$. Most of the disagreement, however, is relative to the US labor markets and it is limited to moderate differences in the wage impact of immigrants on less educated workers. We take a different approach here. We capture the range of disagreement across economists with different estimates of the fundamental parameters of our labor market model. In particular, different choices of the elasticity of relative demand between college and non-college educated and between native and immigrant workers as well as differences in the strength of human capital externalities can be varied to produce different scenarios. Those can be associated with pessimistic, intermediate, and optimistic views of the labor market effects of immigrants. Without taking any stand on the current debate we will show what range of effects one obtains by allowing the whole reasonable spectrum of parameter estimates.

Are there some common findings irrespective of the parameter choice? The answer is yes, because some general results emerge from these simulations. First, in general, over the period 1990-2000 immigration had a small positive or no effect on the average wages of non-migrant natives in all the OECD countries. These effects were, usually, positively correlated with the immigration rate of the country (the size of immigrant flow relative to the population). They ranged from 0 to $+4 \%$. Canada, Australia and New Zealand, which adopted immigration policies explicitly selecting in favor of highly educated, had significant positive wage gains from immigration for natives. However, also countries such as Luxembourg, Malta, Cyprus, the United Kingdom, and Switzerland (which did not explicitly select their immigrants based on education) experienced positive average wage effects between 1 to 3\%. Second, immigration had even more beneficial effects on wages of non-college educated workers in OECD countries. These effects ranged between 0 and $+6 \%$. For some countries, such as Ireland, Canada, Australia, United Kingdom, and Switzerland, the effects are in the 2-4\% range. Only Austria, Denmark, Italy, Japan and Greece show estimated effects on the wages of less educated (in the most pessimistic scenario) that are close to 0. A corollary of this result is that immigration reduced the wage differential between more and less educated natives. Third, emigration, to the contrary, had a negative and significant effect on wages of

${ }^{2}$ The estimates in Borjas (2003) and Card $(2001,2009)$ are considered as spanning the range between the more pessimistic and more optimistic views of the labor market effects of immigrants. 
less educated natives ranging between 0 and -7\%. In countries like Cyprus, Ireland and New Zealand, less educated workers suffered a wage decrease between 3 and $6 \%$ due to emigration of the highly skilled. Even in Portugal, United Kingdom, South Korea, Latvia, and Slovenia less educated suffered losses between 1 and $2 \%$ because of emigration.

All three results logically proceed from the nature of measured migrant flows from 1990 to 2000. OECD countries have experienced both immigration and emigration flows of workers that were more "college-intensive" than their domestic labor force. Under these conditions, immigration is associated with average wage gains of less educated workers. Emigration, to the contrary, induces average wage losses for less educated non-migrants.

As the skill composition of migrants is crucial in determining our relative and average wage results, we attempt to correct for the "effective" skill content of immigrants in a series of checks. First, we use estimates of the extent of illegal immigration (from the recent "Clandestino" study, performed in several European countries) to correct for the inflows of undocumented migrants. Second, we account for the potential "downgrading" of immigrants' skills in the host countries' labor market, by using their occupational choice as of 2000. Third, we focus on immigration from non-OECD countries which is often portrayed as particularly low skilled. All corrections reduce the percentage of "effective" highly educated immigrants in OECD countries. However, none of them eliminates or reverses the general picture described above: when immigration changed the educational composition of residents, it changed it by increasing the share of college educated (highly skilled). Finally we re-do the exercises for a subset of countries for which we have provisional net immigration data for the 2000s (2000-2007). We choose some European countries that received large immigration flows (including Luxembourg, Spain and Greece which were very large receivers of immigrants), and the United States. For these countries data from the EU Labor Force Survey or from the American Community Survey are available. They are based on smaller samples relative to the censuses and hence subject to larger measurement errors. Even in this case, however, we find that the effects of the more recent immigration flows are between zero and positive for all countries. For Luxembourg, the biggest recipient of immigrants in this period, they can be as large as $+6 \%$ for less educated. For Spain, usually considered as the country most affected by immigrants in the 2000's, the wage effect on less educated natives range between 0 and $+2 \%$. $^{3}$

The rest of the paper is organized as follows. Section 2 presents the simple aggregate production and labor supply framework from which we derive wages and employment effects of exogenous immigration and emigration shocks. Section 3 describes the data, their construction, the main sources, and it shows some simple summary statistics about the educational structure of labor force and migrant data. Section 4 presents the basic results of the simulated wage effects of immigrants using our model and the range of parameters available from the literature. Section 5 considers the wage effect when accounting for undocumented workers, for downgrading of skills, looking at non-OECD immigrants, and using

\footnotetext{
${ }^{3}$ In the Appendix C, we also account for sluggish capital adjustment in the short-run (rather than assume perfectly elastic capital supply), using estimates of the speed of adjustment from the literature. In this case, Spain and Cyprus exhibit a negative short-run impact on wage of less educated, when accounting for downgrading, undocumented and slow capital adjustment. The effects are between -1 and $-2 \%$. For all other countries experiencing net immigration, the short-run effect on wages of less educated are very small (between -0.5 and $+0.5 \%$ ) and for Luxembourg they are still positive at $+2.2 \%$.
} 
the preliminary data on net immigration in the 2000's. Section 6 concludes.

\section{Model}

We construct a simple aggregate model of an economy where the workers in the labor force are differentiated by their place of birth (native versus foreign born) as well as their education and skill levels (high versus low) ${ }^{4}$. This structure allows us to examine the wage and employment effects of immigration of foreign workers into the country and emigration of native workers to other countries as these movements shift the relative composition of workers of different education levels. The model shows that the main effects of migration patterns on employment levels and wages of non-migrant natives depend crucially on the size and the educational composition of immigrants and emigrants relative to the non-migrants as well as the parameters of the model. The key parameters are the elasticities of substitution across workers of different nationalities and education levels and the elasticity of native labor supply.

\subsection{Aggregate production function}

The prevalent models in the literature (Borjas 2003, Card 2001, Ottaviano and Peri forthcoming) are based on a production function where the labor aggregate is a nested constant elasticity of substitution (CES) aggregation of different types of workers. In the production function (where country subscripts are omitted for simplicity), we assume that output (denoted by $y$ ) is produced with a constant-returns-to-scale Cobb-Douglas production function with two factors, physical capital $(k)$, and a composite labor input $(q)^{5}$ :

$$
y=\widetilde{A} k^{1-\alpha} q^{\alpha}
$$

The term $\widetilde{A}$ is the total factor productivity (TFP) parameter, and $\alpha$ is the income share of labor.

Assuming that physical capital is internationally mobile and that each single country is too small to affect global capital markets, returns to physical capital are equalized across countries. If $R^{*}$ denotes the international net rate of return to capital, the following arbitrage condition implicitly defines the equilibrium capital-to-labor ratio in the economy:

$$
R^{*}=(1-\alpha) \widetilde{A} k^{-\alpha} q^{\alpha}
$$

The condition above holds both in the short and the long run in a small open economy. In a closed economy, as in Ramsey (1928) or Solow (1956), condition (2) holds on the long-run balanced growth path, with $R^{*}$ as a function of the inter-temporal discount rate of individuals (or of the savings rate) ${ }^{6}$. We substitute this arbitrage condition into (1) to obtain

\footnotetext{
${ }^{4}$ Even though there are clear and important differences between skill or education, they are used interchangeably in this section. High-skilled (low-skilled) or highly educated (less educated) are equivalent. In the next section, we use tertiary education as the proxy for high-skilled.

${ }^{5}$ All variables are relative to a specific year, $t$. We omit the subscript for compactness of notation.

${ }^{6}$ As long as immigration does not change the saving rate of an economy, the pre- and post-migration $R^{*}$ will be identical.
} 
an expression of aggregate output as a linear function of the aggregate composite labor $q$ :

$$
y=A q
$$

In this expression, $A \equiv \widetilde{A}^{1 / \alpha}\left[(1-\alpha) / R^{*}\right]^{(1-\alpha) / \alpha}$ is an increasing function of TFP and is referred to as modified TFP. The production function (3) can be viewed as an aggregate production function in which inputs (workers) are adjusted instantly. Long-run and short run effects of a change in labor supply are the same as there are no "slowly" accumulating factors. Alternatively, equation (3) can be interpreted as the reduced long-run version of a function with capital accumulation. In the long-run (balanced growth path) analysis, the two interpretations are equivalent. Our simulation exercise assumes that capital is immediately adjusted (constant interest rate). In Appendix $\mathrm{C}$, we provide simulation results with a fixed capital stock for comparison.

Many papers in the labor (Katz and Murphy 1992, Card and Lemieux 2001, Acemoglu and Zilibotti 2001) and growth (Caselli and Coleman 2006) literatures assume that labor in efficiency units, denoted as $q$ below, is a nested CES function of highly-educated $\left(q_{h}\right)$ and less-educated workers $\left(q_{l}\right)$ :

$$
q=\left[\theta_{q} q_{h}^{\frac{\sigma_{q}-1}{\sigma_{q}}}+\left(1-\theta_{q}\right) q_{l}^{\frac{\sigma_{q}-1}{\sigma_{q}}}\right]^{\frac{\sigma_{q}}{\sigma_{q}-1}}
$$

where $\theta_{q}$ and $1-\theta_{q}$ are the productivity levels of highly-educated workers (college level or above) and less educated workers (non-college). The parameter $\sigma_{q}$ is the elasticity of substitution between these two types of workers.

We next distinguish between natives and immigrants within each education specific labor aggregate, $q_{h}$ and $q_{l}$. If native and immigrant workers of education level $i=(h, l)$ were perfectly substitutable, the economy-wide aggregate $q_{i}$ would simply be equal to the sum of the native and immigrant labor supplies. However, native and immigrant workers of similar education levels may differ in several respects. First, immigrants have skills, motivation, and tastes that may set them apart from natives. Second, in manual and intellectual work, they may have culture-specific skills and limitations such as limited knowledge of the language or culture of the host country. Third, immigrants tend to concentrate in occupations different from those mostly chosen by natives because of diaspora networks, information constraints and historical accidents. In particular, new immigrants tend to cluster disproportionately in those sectors or occupations where previous migrant cohorts are already over-represented. Several papers (Card, 2009; D'Amuri et al. 2010; Ottaviano and Peri, forthcoming; Manacorda et al., forthcoming) find imperfect degrees of substitution between natives and immigrants. Hence, we assume that both highly-educated $\left(q_{h}\right)$ and less-educated labor aggregates $\left(q_{l}\right)$ are both nested CES functions of native and immigrant labor stocks with the respective education levels. This is represented as:

$$
q_{i}=\left[\theta_{n} q_{i, n}^{\frac{\sigma_{m}-1}{\sigma_{m}}}+\left(1-\theta_{n}\right) q_{i, f}^{\frac{\sigma_{m}-1}{\sigma_{m}}}\right]^{\frac{\sigma_{m}}{\sigma_{m}-1}} \quad \text { where } i=h, l
$$

where $q_{i, n}$ is the number of type- $i$ native workers, $q_{i, f}$ is the number of type- $i$ immigrant workers, and $\sigma_{m}$ is the elasticity of substitution between natives and immigrant workers. Finally, $\theta_{n}$ and $1-\theta_{n}$ are the relative productivity levels of native and immigrant workers, respectively. 


\subsection{Schooling externalities}

We introduce the existence of positive externalities from highly skilled workers in the same spirit as several recent papers (see Acemoglu and Angrist 2000, Ciccone and Peri 2006, Moretti 2004a, 2004b, and Iranzo and Peri 2009 as recent examples). There is a large body of literature (beginning with Lucas 1988, and extending to Azariadis and Drazen 1990, Benhabib and Spiegel 2005, Cohen and Soto 2007, and Vandenbussche et al. 2009) that emphasizes the role of human capital on technological progress, innovation and growth of GDP per capita. The main implication is that TFP is an increasing function of the schooling level in the labor force. Such formulation is particularly appropriate for our model. Following the expressions used in Moretti (2004a, 2004b), the TFP is expressed as follows ,

$$
A=A_{0} e^{\lambda f_{h}}
$$

where $A_{0}$ captures the part of TFP that is independent of the human capital externality;

$f_{h} \equiv \frac{Q_{h, n}+Q_{h, f}}{Q_{h, n}+Q_{h, f}+Q_{l, n}+Q_{l, f}}$ is the fraction of highly educated individuals in the labor force (where $Q_{i, j}$ is the total number of individuals with education $i$ and nativity-status $j$ in working age), ${ }^{7}$ and $\lambda$ is the semi-elasticity of the modified TFP to $f_{h}$. Throughout the paper, upper-case characters denote total working-age population whereas lower-case letters (such as $q_{i, j}$ ) are individuals who are actually employed. Acemoglu and Angrist (2000) as well as Iranzo and Peri (2009) use a similar formulation to express schooling externalities and we use their estimates for the parameter $\lambda$.

\subsection{Labor Demand}

Each country is a single labor market. We derive the marginal productivity for native workers of both education levels $\left(w_{h, n}\right.$ and $\left.w_{l, n}\right)$ by substituting (4) and (5) into (3) and taking the derivative with respect to the total quantity of labor $q_{h, n}$ and $q_{l, n}$ respectively. This yields the following expressions which define the labor demand for each type of native workers:

$$
\begin{aligned}
& w_{h, n}=A \theta_{q} \theta_{n}\left(\frac{q}{q_{h}}\right)^{\frac{1}{\sigma_{q}}}\left(\frac{q_{h}}{q_{h, n}}\right)^{\frac{1}{\sigma_{m}}} \\
& w_{l, n}=A\left(1-\theta_{q}\right) \theta_{n}\left(\frac{q}{q_{l}}\right)^{\frac{1}{\sigma_{q}}}\left(\frac{q_{l}}{q_{l, n}}\right)^{\frac{1}{\sigma_{m}}}
\end{aligned}
$$

By taking the logarithm of the demand functions above and calculating the total differentials of each one of them with respect to infinitesimal variations $(\Delta)$ of the employment of each type of worker, we obtain the percentage change in marginal productivity in response to employment changes. In particular, the percentage change of marginal productivity for native workers of education level $i=(h, l)$ in response to a percentage change in employment of immigrant $\left(\Delta q_{h, f} / q_{h, f}\right.$ and $\left.\Delta q_{l, f} / q_{l, f}\right)$ and native $\left(\Delta q_{h, n} / q_{h, n}\right.$ and $\left.\Delta q_{l, n} / q_{l, n}\right)$ workers can be written as follows: 8

\footnotetext{
${ }^{7}$ We assume that the schooling externality is a function of the proportion of the college educated working age population, and they represent the total pool of potential workers in the long-run. In practice this number is very close to the proportion of the college educated workers in the actual labor force but this structure simplifies the analysis considerably.

${ }^{8}$ The details of the derivation are in the Appendix B .
} 


$$
\begin{aligned}
\frac{\Delta w_{i, n}}{w_{i, n}}= & \frac{1}{\sigma_{q}}\left(s h_{h, f} \frac{\Delta q_{h, f}}{q_{h, f}}+s h_{l, f} \frac{\Delta q_{l, f}}{q_{l, f}}+s h_{h, n} \frac{\Delta q_{h, n}}{q_{h, n}}+s h_{l, n} \frac{\Delta q_{l, n}}{q_{l, n}}\right)+ \\
& \left(\frac{1}{\sigma_{m}}-\frac{1}{\sigma_{q}}\right)\left(\frac{s h_{i, f}}{s h_{i}} \frac{\Delta q_{i, f}}{q_{i, f}}+\frac{s h_{i, n}}{s h_{i}} \frac{\Delta q_{i, n}}{q_{i, n}}\right)-\frac{1}{\sigma_{m}} \frac{\Delta q_{i, n}}{q_{i, n}}+\lambda \Delta f_{h} \text { for } \quad i=(h, l)
\end{aligned}
$$

In equation (9), the terms $s h_{i, j}$ represent the share of the wage bill going to workers of education level $i=(h, l)$ and place of origin $j=(n, f)$. The first term in the summation captures the effect of changes in the employment of each group on the marginal productivity of natives of type $i$ through the term $q$ in the wage equation. The second term in the summation, which depends only on the change in supply of workers of the same education type (natives or immigrants), is the impact on marginal productivity of natives of type $i$ through the terms $q_{i}$ in the wage equation. The term $-\frac{1}{\sigma_{m}} \frac{\Delta q_{i, n}}{q_{i, n}}$ captures the impact through the term $q_{h, n}^{-\frac{1}{\sigma_{m}}}$. The final term $\lambda \Delta f_{h}$ is the effect of a potential change in education intensity, measured as a change in the share of the college educated in the working-age population, through the total factor productivity level $A$.

\subsection{Labor supply}

A native worker of education level $i=(h, l)$ chooses how to split one unit of labor endowment between work $l_{i}$ and leisure $1-l_{i}$ to maximize an instant utility function, ${ }^{9}$ which depends positively on consumption $c_{i}$ and negatively on the amount of labor supplied $l_{i}$ :

$$
U_{i}=\theta_{c} c_{i}^{\delta}-\theta_{l} l_{i}^{\eta}
$$

The parameters $\theta_{c}, \theta_{l}, \delta$ and $\eta(\geq \delta)$ can be specific to the education level $i$ but we consider them to be identical across groups for simplicity. In production function (3), individuals consume all their labor income which leads to the budget constraint $c_{i}=l_{i} w_{i, n}$. Substituting this constraint into the utility function and maximizing with respect to $l_{i}$ we obtain the labor supply for the individual worker:

$$
l_{i}=\phi w_{i, n}^{\gamma}
$$

where $\phi=\left(\frac{\theta_{c} \delta}{\theta_{l} \eta}\right)^{\frac{\delta}{\eta-\delta}}$ is a constant and $\gamma=\frac{\delta}{\eta-\delta} \geqq 0$ captures the elasticity of household labor supply. Since there are $Q_{i, n}$ working age individuals among all workers of education level $i$, the aggregate labor supply of that type is given by:

$$
q_{i, n}=\phi Q_{i, n} w_{i, n}^{\gamma} \text { for } i=(h, l)
$$

\footnotetext{
${ }^{9}$ The model with savings and capital accumulation could be solved with the alternative utility function $U=\frac{c^{1-\theta} \exp (-\zeta l)-1}{1-\theta}$ as an inter-temporal optimization model. In that case, which is illustrated at page 422-25 of Barro and Sala-i-Martin (2003) the labor supply along a balanced growth path does not depend on wages. Consumption would be a constant fraction of income and, along a balanced growth path wages would be growing at the rate of $\widetilde{A}$. Hence it would be a special case with perfectly inelastic individual labor supply.
} 
As described above, $w_{i, n}$ is the wage paid to a native worker of schooling $i ; Q_{i, n}$ (defined in section 2.2) is the working-age population in group $i ; \gamma \geqslant 0$ is the elasticity of labor supply and $\phi$ is a constant.

For immigrants, we make a further simplification by assuming that all immigrants at working age supply a constant amount of labor (call it $\phi_{f}>0$ ) so that total employment of immigrants is given by $q_{i, f}=\phi_{f} Q_{i, f}$ for $i=(h, l)$. This is equivalent to the assumption that employment levels of immigrants are not responsive to changes in wages. It is also equivalent to considering the immigration level as exogenous while tracking its labor market impact on natives and is the standard approach in the labor literature when analyzing the impact of immigration on native workers (e.g. in Borjas 2003, Borjas and Katz 2007, Ottaviano and Peri, forthcoming).

\subsection{Equilibrium effect of exogenous immigration and emigration}

Exogenous changes in the working-age foreign-born population $\left(\Delta Q_{h, f}\right.$ and $\left.\Delta Q_{l, f}\right)$ and in the working-age native population $\left(\Delta Q_{h, n}\right.$ and $\left.\Delta Q_{l, n}\right)$ are what we call net immigration and net emigration. They generate changes in the marginal productivity of native workers as well as changes in their supply. In the new equilibrium, each of the two labor markets (for highly-educated and less-educated native workers) respond to these flows and adjust to new wage and employment levels.

For compactness, we define $\widehat{x}=\Delta x / x$ as the percentage change of any variable $x$. Considering an immigration "shock" represented by $\widehat{Q}_{i, f}$ and an emigration "shock" represented by $\widehat{Q}_{i, n}$ for $i=(h, l)$, the following two conditions (for each labor market) represent the percentage change in demand and supply of native labor:

$$
\begin{aligned}
& \widehat{w}_{i, n}= \frac{1}{\sigma_{q}}\left(s h_{h, f} \widehat{Q}_{h, f}+s h_{l, f} \widehat{Q}_{l, f}+s h_{h, n} \widehat{q}_{h, n}+s h_{l, n} \widehat{q}_{l, n}\right)+ \\
&\left(\frac{1}{\sigma_{m}}-\frac{1}{\sigma_{q}}\right)\left(\frac{s h_{i, f}}{s h_{i}} \widehat{Q}_{i, f}+\frac{s h_{i, n}}{s h_{i}} \widehat{q}_{i, n}\right)-\frac{1}{\sigma_{m}} \widehat{q}_{i, n}+\lambda \Delta f_{h} \text { for } i=(h, l) \\
& \widehat{w}_{i, n}=\frac{1}{\gamma}\left(\widehat{q}_{i, n}-\widehat{Q}_{i, n}\right) \text { for } i=(h, l)
\end{aligned}
$$

The new equilibrium is obtained by equating the percentage wage changes in the demand and supply of native labor within each market and solving for $\widehat{q}_{i, n}$.

Let $\widehat{w}_{i, n}^{m}$ denote the exogenous impact of immigration on the marginal productivity of native workers of education level $i$. Its value is obtained by setting $\widehat{q}_{i, n}=0$ in the labor demand equation (12). This leads to

$$
\widehat{w}_{i, n}^{m}=\left[\frac{1}{\sigma_{q}}\left(s h_{h, f} \widehat{Q}_{h, f}+s h_{l, f} \widehat{Q}_{l, f}\right)+\left(\frac{1}{\sigma_{m}}-\frac{1}{\sigma_{q}}\right) \frac{s h_{i, f}}{s h_{i}} \widehat{Q}_{i, f}+\lambda \Delta f_{h}\right] \text { for } i=(h, l)
$$

After solving the system of equations in (12) and (13), we obtain the following two linear equations in two unknown variables that summarize the equilibrium in each labor market for $i=(h, l)$ : 


$$
\begin{gathered}
\widehat{w}_{h, n}^{m}+\frac{s h_{l, n}}{\sigma_{q}} \widehat{q}_{l, n}+\frac{1}{\gamma} \widehat{Q}_{h, n}-\left(\frac{1}{\gamma}+d_{h}\right) \widehat{q}_{h, n}=0 \\
\widehat{w}_{l, n}^{m}+\frac{s h_{h, n}}{\sigma_{q}} \widehat{q}_{h, n}+\frac{1}{\gamma} \widehat{Q}_{l, n}-\left(\frac{1}{\gamma}+d_{l}\right) \widehat{q}_{l, n}=0
\end{gathered}
$$

In expression (15), the first two terms $\widehat{w}_{h, n}^{m}+\frac{s h_{l, n}}{\sigma_{q}} \widehat{q}_{l, n}$ represent the shift (in percentage terms) of the intercept of the logarithmic demand function for native workers of education level $h$ while $\frac{1}{\gamma} \widehat{Q}_{h, n}$ is the (negative of) the change in the intercept of the logarithmic supply of native workers with education level $h{ }^{10}$ The coefficient $d_{h}=\frac{1}{\sigma_{m}}+\left(\frac{1}{\sigma_{m}}-\frac{1}{\sigma_{q}}\right) \frac{s h_{h, n}}{s h_{h}}-\frac{s h_{h, n}}{\sigma_{q}}$ is the (absolute value) of the slope of the logarithmic demand function for native workers of type $h$ while $\frac{1}{\gamma}$ is the slope of the logarithmic supply for the same workers. ${ }^{11}$

The interactions between the two markets $(h$ and $l$ ) arise from the fact that a change in employment of workers with schooling level $h$ affects the marginal productivity of, and hence the demand for, workers of schooling level $l$ through the term $\frac{s h_{l, n}}{\sigma_{q}} \widehat{q}_{l, n}$. In turn, employment in the $h$ market affects the productivity (and demand) for workers of type $l$ (through $\frac{s h_{h, n}}{\sigma_{q}} \widehat{q}_{h, n}$ ). Solving the system (15)-(16) with respect to $\widehat{q}_{h, n}$ and $\widehat{q}_{l, n}$, we obtain the following equilibrium changes in employment and wages of natives in response to immigration and emigration and we denotes with a star:

$$
\begin{aligned}
& \widehat{q}_{h, n}^{*}=\frac{\left(\frac{1}{\gamma}+d_{l}\right)\left(\widehat{w}_{h, n}^{m}+\frac{1}{\gamma} \widehat{Q}_{h, n}\right)+\frac{s h_{l, n}}{\sigma_{q}}\left(\widehat{w}_{l, n}^{m}+\frac{1}{\gamma} \widehat{Q}_{l, n}\right)}{\left(\frac{1}{\gamma}+d_{l}\right)\left(\frac{1}{\gamma}+d_{h}\right)-\frac{s h_{l, n}}{\sigma_{q}} \frac{s h_{h, n}}{\sigma_{q}}} \\
& \widehat{q}_{l, n}^{*}=\frac{\left(\frac{1}{\gamma}+d_{h}\right)\left(\widehat{w}_{l, n}^{m}+\frac{1}{\gamma} \widehat{Q}_{l, n}\right)+\frac{s h_{h, n}}{\sigma_{q}}\left(\widehat{w}_{h, n}^{m}+\frac{1}{\gamma} \widehat{Q}_{h, n}\right)}{\left(\frac{1}{\gamma}+d_{l}\right)\left(\frac{1}{\gamma}+d_{h}\right)-\frac{s h_{l, n}}{\sigma_{q}} \frac{s h_{h, n}}{\sigma_{q}}}
\end{aligned}
$$

and

$$
w_{i, n}^{*}=\frac{1}{\gamma}\left(\widehat{q}_{i, n}^{*}-\widehat{Q}_{i, n}\right) \text { for } i=(h, l)
$$

\subsection{Special cases}

Two extreme cases are of interest when defining the boundaries of potential wage and employment effects. If wages are perfectly flexible and supply of workers is perfectly inelastic $\left(q_{i, n}=Q_{i, n}\right)$, the whole effect of immigration and emigration shocks accrues to wages. This is a reasonable scenario, especially in the long-run, and it is the one considered in most analyses (such as Borjas 2003). In such a case, there is no endogenous response of native employment

\footnotetext{
${ }^{10}$ Correspondingly, in equation (16) the term $\widehat{w}_{l, n}^{m}+\frac{s h_{h, n}}{\sigma_{q}} \widehat{q}_{h, n}$ is the shift in labor demand for native workers of schooling $l$ and $\frac{1}{\gamma} \widehat{Q}_{l, n}$ is the negative of the change in labor supply for those workers.

${ }^{11}$ Correspondingly, $d_{l}=\frac{1}{\sigma_{m}}+\left(\frac{1}{\sigma_{m}}-\frac{1}{\sigma_{q}}\right) \frac{s h_{l, n}}{s h_{l}}-\frac{s h_{l, n}}{\sigma_{q}}$ is the (absolute value of) the slope of the logarithmic demand for native workers of schooling $l$ while $\frac{1}{\gamma}$ is the slope of their logarithmic supply.
} 
to the exogenous immigration and emigration shocks and the change in equilibrium wages is given by

$$
\begin{aligned}
{\widehat{w_{i, n}}}^{*}= & \frac{1}{\sigma_{q}}\left(s h_{h, f} \widehat{Q}_{h, f}+s h_{l, f} \widehat{Q}_{l, f}+s h_{h, n} \widehat{Q}_{h, n}+s h_{l, n} \widehat{Q}_{l, n}\right)+ \\
& \left(\frac{1}{\sigma_{m}}-\frac{1}{\sigma_{q}}\right)\left(\frac{s h_{i, f}}{s h_{i}} \widehat{Q}_{i, f}+\frac{s h_{i, n}}{s h_{i}} \widehat{Q}_{i, n}\right)-\frac{1}{\sigma_{m}} \widehat{Q}_{i, n}+\lambda \Delta f_{h} \text { for } i=(h, l)
\end{aligned}
$$

At the opposite extreme of the spectrum, the wages could be completely rigid so that any change in immigration is absorbed by changes in employment levels. In this case, there is no wage impact of immigration and the employment response of natives to the inflow of immigrants is given by

$$
\begin{gathered}
\widehat{q}_{h, n}^{*}=\frac{d_{l} \widehat{w}_{h, n}^{m}+\frac{s h_{l, n}}{\sigma_{q}} \widehat{w}_{l, n}^{m}}{d_{l} d_{h}-\frac{s h_{l, n}}{\sigma_{q}} \frac{s h_{h, n}}{\sigma_{q}}} \\
\widehat{q}_{l, n}^{*}=\frac{d_{h} \widehat{w}_{l, n}^{m}+\frac{s h_{h, n}}{\sigma_{q}} \widehat{w}_{h, n}^{m}}{d_{l} d_{h}-\frac{s h_{l, n}}{\sigma_{q}} \frac{s h_{h, n}}{\sigma_{q}}}
\end{gathered}
$$

An assumption of full wage rigidity in the long-run, however, creates many inconsistencies since most estimates imply the elasticity of labor supply to wages is much closer to zero than to infinity. Thus, this scenario should be viewed as a theoretical exercise.

\section{Description of the New Data-Set}

\subsection{Net migration data: sources and definitions}

The relevant migration flows to be used in our analysis are net immigration and emigration flows, namely gross flows of immigrants and emigrants net of returnees. The figures for immigrants are calculated using the stock of foreign-born individuals (or foreign nationals) for each country in two different years (1990 and 2000) and taking the difference between the two. The figures for emigrants are calculated for each country of origin by aggregating the stock of people living in other countries in two different years and taking the difference between the two.

There are several sources documenting yearly migration flows by receiving country (e.g. OECD International Migration Database, UN migration statistics) but those only include gross inflow of people in a country and they do not correct for migrants who leave or go back to their country of origin. Moreover they never record undocumented migrants and they often record immigrants when they achieve their resident status rather than when they first enter the country. Most importantly for our purposes, those data do not have information on the education level of migrants. The flows of immigrants to a country can only be recovered by measuring the stock of foreign born people in a destination country (from a certain origin

country) at different points in time and then taking the difference. The other advantage of using data on stocks of migrants is that they are from national censuses which tend to be 
more representative, more accurate and more complete than other data sources. Censuses (i) often account for undocumented immigrants at least in some countries like the US, (ii) they categorize immigrants by place of birth, rather than nationality which can change over time and across countries due to naturalization laws and (iii) report their education levels.

Our database was constructed by two of the authors and is described in greater detail in Docquier et al. (2010). ${ }^{12}$ It consists of measures of bilateral immigrant and emigrant stocks for 195 countries in 1990 and 2000. The starting point for the new data is the database assembled by Docquier and Marfouk (2006) who collected the stock of foreignborn individuals in all OECD destination countries in 1990 and 2000, by country of origin and level of schooling (primary, secondary and tertiary), using censuses as primary data sources. These data were supplemented with original data from the censuses of a large number of non-OECD countries. Finally, for many destination countries with no data, bilateral migrant stocks were predicted using a gravity framework as described in greater detail in Docquier et al. (2010). Table A1 in the appendix shows the estimated total stock of migrants in OECD countries, in non-OECD countries with observed data, and in non-OECD countries with imputed data. As we can see, about 70-77\% of world migrants are in countries with census data and only $23-30 \%$ of them are in countries with imputed data. Measuring emigration from OECD countries requires data from all the possible destination countries, at least the most relevant ones. Emigrant stocks from a certain country of origin can only be measured by aggregating all migrants recorded in the censuses of all destination countries. As some important destination countries (such as Russia, South Africa, Brazil, Argentina, and Singapore) are outside the OECD, this new database ensures much better coverage of emigrants from OECD countries relative to Docquier and Marfouk (2006). Table A2 in the appendix show that the majority of emigrants from the countries considered in this study are in destination countries for which we have actual census data. ${ }^{13}$ Less than $13 \%$ of emigrants from most countries of origin are in countries with imputed (rather than actual) migration data. The only countries relying on imputed data for a larger fraction of their emigrants (up to $40 \%$ ) are Israel, the Baltic States, and France. ${ }^{14}$

We distinguish two schooling types indexed by $i . i=H$ denotes college graduates (also referred to as highly educated) and $i=L$ denotes individuals with secondary completed or lower education (referred to as less educated). The database covers the years 1990 and 2000 and the differences in stocks by country of origin and destination provide the measures of the net migration flows in the 1990's. The data are relative to individuals aged 25 and over as a proxy of the working-age population. This choice maximizes comparability between data on migration and on labor force per educational attainment. Furthermore, it excludes a large number of students who emigrate temporarily to complete their education or children who migrate with their families and are not active in the labor market.

The final data needed are the number and average education levels of working-age residents in each country in our sample. The size of the adult population (i.e. population aged 25 and over) is provided by the United Nations. Missing data in the case of several

\footnotetext{
${ }^{12}$ Further details of the construction and specific references are also in Appendix A and Table A1.

${ }^{13}$ This pattern is also confirmed in Ozden et.al. (2010) which presents global bilateral migration stocks but does not disaggregate by education levels.

${ }^{14}$ Also, for this reason we will consider Israel and the Baltic States as outliers in most of our simulations.
} 
small countries can be estimated using the CIA world factbook. ${ }^{15}$ Adult population data is then split across education groups using international indicators of educational attainment. We follow Docquier and Marfouk (2006) and Docquier, Lowell and Marfouk (2009) in combining different data sets documenting the proportion of tertiary educated workers in the population aged 25 and over. The main sources are De La Fuente and Domenech (2006) for OECD countries and Barro and Lee (2010) and Cohen and Soto (2007) for non-OECD countries. In the remaining non-OECD countries where both Barro-Lee and Cohen-Soto data are missing (about 70 countries in 2000), they apply the educational proportion of the neighboring country with the closest tertiary education enrollment rate and the GDP per capita.

\subsection{Description and General Trends}

Table 1 presents the immigration patterns during the period 1990-2000 for all the countries considered in this study. These are all member countries of the OECD as well as several nonOECD countries in Eastern Europe. Columns 1 and 2 show immigration rates in total population and among college educated. Columns 3 and 4 show immigration rates, considering only non-OECD countries of origin, also distinguished between total and College-educated. Immigration rates, in column 1 of Table 1 are calculated as net inflow of immigrants (age 25 and older) during the period $1990-2000^{16}$ divided by the initial working-age population in 1990. For instance, during this time period, the net inflow of immigrants was equal to $14.35 \%$ of the 1990 population in Israel. This large level is a consequence of the removal of the emigration restrictions in a very unstable Soviet Union in the early 1990s. ${ }^{17}$ A less well known fact is that Luxembourg, Austria, and Ireland also received significant inflows of immigrants relative to their populations. The total rates range between 7.6 and $12.5 \%$. Three countries at the bottom of the table are also worth mentioning. The three Baltic countries (Estonia, Latvia and Lithuania), emerging after the collapse of the Soviet Union, experienced massive negative net immigration flows. This was a result of the return migration of many ethnic Russians back to Russia, after having immigrated to these Baltic countries during the Soviet era. Several other Eastern European countries (e.g. Romania, Slovenia, Hungary and Poland) had similar experiences during this period.

The second column of Table 1 presents the net immigration rates for College educated workers, referred to as "highly educated". These are calculated as the net change (between 1990 and 2000) in the stock of college educated foreign-born workers $\left(\Delta Q_{h, f}\right)$ relative to the similarly educated resident population in 1990. Two interesting patterns are worth emphasizing. First, in all countries with positive net immigration rates, (with the exception of Austria), the immigration rates of the college educated were larger than the rates for the total population. In some prominent destinations such as Israel, Ireland, Iceland, Canada, Australia and the United Kingdom, the immigration rates for college educated workers were more than twice the overall immigration rates. Immigration, therefore, contributed to a significant increase in the share of college educated individuals in the resident population

\footnotetext{
${ }^{15}$ See http://www.cia.gov/cia/publications/factbook.

${ }^{16}$ This is denoted by $\Delta Q_{h, f}+\Delta Q_{l, f}$ using the notation of the model in section (2).

${ }^{17}$ There are several studies analyzing the economic impact of this episode on Israel's economy such as Friedberg (2001), Cohen-Goldberg and Pasermann (forthcoming).
} 
for all countries in our sample (again with the exception of Austria). Second, Latvia and Estonia had negative immigration rates, implying large returns of immigrants and even larger return rates for college educated. Remarkably, columns 3 and 4 confirm the pattern of larger immigration rates for college educated individuals, even when we consider only immigrants from non-OECD countries. Most countries have higher rates for college immigration than for total immigration even from non-OECD countries and countries like Canada, Australia, and the UK attract very college-intensive flows of migrants from outside the OECD.

Table 2 presents the emigration rates for the countries in our sample where Column 1 is the total emigration rate, calculated as the net outflow of natives (25 year and older) during the period 1990-2000 $\left(\Delta Q_{h, n}+\Delta Q_{l, n}\right)$ relative to the total resident population (again age 25 and above) in 1990. Column 2 contains the net emigration rate of college-educated natives. A negative emigration rate implies that the return rate of emigrants (natives who were already abroad in 1990) was larger than the outflow of new emigrants during the period 1990-2000. Countries are ranked in decreasing order of their college emigration rates. Few observations are in order. First, as in the case of immigration, emigration rates are also larger for college educated natives than on average (with the exception of Israel). For some small countries (Cyprus, Malta, and Ireland), a large emigration rate for the college educated is associated with negative overall emigration rates, implying large rate of return for non-college educated natives from abroad. In some of these small countries, however, immigration of tertiary educated foreign born workers compensated the emigration of the natives. Second, several Eastern European countries (such as Poland, Romania, Slovenia, and Slovakia) and some western European countries (Portugal and Greece) had significant college educated emigration flows, that were not compensated by similar immigration inflows. For those countries, emigration was a significant source of change in the supply of highly educated workers in the overall labor supply. Other European countries such as the United Kingdom, Luxembourg, Switzerland, and the Netherlands had significant rates of collegeeducated emigration but were compensated with significant immigration from mostly nonOECD countries. Third, the United States, Canada, and Australia were, as is widely known, mainly destination countries as the immigration rates (total and for highly educated) were much larger than the corresponding emigration rates of the natives. In summary, during the 1990s both the immigration and emigration flows were very skill-intensive in most OECD countries. Less well-known, but clearly visible in our data, many countries experienced emigration rates that were just as large as immigration rates.

\section{Simulated labor-market effects}

\subsection{Parameterization and measurement}

Our model is designed to evaluate the wage and employment effects of migration patterns on non-migrant natives. As one can see from equations (17)-(19), we need three key sets of variables for each country in order to determine these effects. The first is the share of the wage income that accrues to each of the four main groups in the labor force as of 1990. As mentioned in the previous section, these groups are denoted as $s h_{i, j}$, where $i$ is the 
education level and $j$ is the country of birth. ${ }^{18}$ The second variable is the percentage change in employment among each of these four groups due to immigration and emigration during the decade 1990-2000. This is denoted by $\widehat{Q}_{i, j}$. The last variable is the change in the ratio of college educated individuals in the labor force, again due to immigration and emigration, which we denote by $\Delta f_{H}$.

The shares of wage income accruing to different groups of workers depend on their employment levels and wages. We use their number in the working-age population as a measure of their share in the labor force (from Docquier et al. 2010). Since there is no comprehensive global database on wages of college educated and less educated, we proceed as follows. We take the estimated returns to a year of schooling in each country for the year as close as possible to 1990 from the Hendricks (2004) database. ${ }^{19}$ We then calculate the average years of education for each of the two education groups (those with and without college degrees) using the Barro and Lee (2010) database. We multiply the return on education with the difference between average years of schooling of the two groups to identify the college wage premium in a given country. Then, from several different sources (most of which are reviewed in Kerr and Kerr, 2009), we obtain the country-specific estimate of the native-foreign wage premium to adjust the wages of immigrants at each level of education. If any of the data are not available for a specific country, we use the estimate for the geographically closest country with the most similar income per capita. Multiplying the group-specific employment by the group-specific wage (standardized for the wage of less educated natives) we obtain the wage bill for that group. When divided by the total wage bill, this number provides the share $s h_{i, j}$. These shares of wage income for each of the four groups in each country are reported in Table A3 of the appendix. The percentage change in the employment of each group during the period 1990-2000, due to immigration and emigration, as well as the change in share of college-educated, are calculated from the dataset on stocks of migrants in 1990-2000 as described above.

The next critical step is the determination of the values of the four fundamental parameters of the model. $\sigma_{q}$ is the elasticity of substitution between highly- and less-educated workers; $\sigma_{m}$ is the elasticity of substitution between natives and immigrants with the same education level; $\lambda$ is the intensity of college-externalities, and $\gamma$ is the labor supply elasticity of more and less educated natives.

Table 3 presents the values of the parameters chosen in each of three scenarios considered in the numerical simulations. The values span the range found in the literature. For the parameter $\sigma_{q}$, the elasticity of substitution between more and less educated workers, there are several estimates in the literature. Johnson (1970) and Murphy et al. (1998) estimate values around 1.30 (respectively 1.34 and 1.36); Angrist (1995), Katz and Murphy (1992), Ciccone and Peri (2005), and Krusell et al. (2000) estimate values around 1.5-1.75 (respectively 1.47, $1.50,1.66$ ) and Ottaviano and Peri (forthcoming) estimate a value close to 2 . Hence, we use the values $1.5,1.75$ and 2 for the three main scenarios.

The parameter $\sigma_{m}$, the elasticity of substitution between natives and immigrants, has

\footnotetext{
${ }^{18}$ Recall that each worker has two key attributes. The first is the education level and denoted by $i=(h, l)$, where $h$ stands for highly (or tertiary) educated and $l$ is less educated. Second, $j=(n, f)$ indicates the country of origin, where $n$ stands for native and $f$ is foreign born.

${ }^{19}$ If the estimate was not available for a country we choose the estimate for the country sharing a border with the closest level of income per capite.
} 
been the subject of several recent papers and has generated a certain level of debate. This parameter is particularly crucial to determine the effect of immigration on the wages of nonmigrant natives and, as we will see, the choice of this parameter influences the estimated wage-effects of migration in some countries much more than other parameters. Borjas et al. (2008), Peri (2011), and Ottaviano and Peri (forthcoming) use US data and Manacorda et al. (forthcoming) use UK data in their estimation of $\sigma_{m}$. The first study finds a value of infinity, the second and third estimate an elasticity between 10 and 20 and the paper on UK data finds a value of 6 . We use infinity, 20, and 6 as the three parameter values in the three scenarios.

The parameter $\lambda$, measuring the externality generated by the tertiary educated in the labor force, has been estimated using data from US cities (Moretti 2004a, 2004b) or US states (Acemoglu and Angrist 2000 and Iranzo and Peri 2009). It is also subject to a certain level of debate since some studies find substantial schooling externalities $(\lambda=0.75$ in Moretti 2004b) while others do not ( $\lambda=0$ in Acemoglu and Angrist 2000).

Finally, the estimates of the elasticity of labor supply $\gamma$ (as summarized in the review by Evers et al (2008) for several European countries and the US) range from 0 to 0.17 (in a study on the US by Flood and MaCurdy 1992 and on the Netherlands by van Soest et. al. 1990). Hence, we choose $0,0.10$, and 0.20 as the representative values for this parameter.

\subsection{Wage effects of immigration}

The effects of immigration, in percentage points, on the wages of less educated native workers are shown in Figure 1.a and those on the average wages of all workers in the economy are illustrated in Figure 1.b. We report these figures as a large part of the debate on the labor market effects of immigration has been around the overall wage effects and the effects on the least educated. ${ }^{20}$ Each figure reports the values obtained from the formulas (19) and the three configurations of the parameters shown in Table 3 (which we refer to as the "low", "intermediate", and "high" elasticity scenarios). The thin dotted line connects the estimates from the high scenario, the thick solid line connects estimates in the intermediate scenario and the thin dashed line connects the low scenario estimates. The numerical values corresponding to the figures are reported in Table A4 of the Appendix. Our attention is more focused on the less educated workers since they are usually considered to be more affected from the disruptive labor market impact of immigration in academic studies (e.g. Borjas 2003) as well as the public opinion. The average wage effect, on the other hand, gives us a better idea about the overall effect of immigration on national income in the long run. While in Table A4 we report the effects for all 39 countries in our sample (all OECD plus the remaining European Countries as discussed above), we drop Israel and the Baltic countries (Lithuania, Latvia, and Estonia) in Figures 1.a and 1.b. Israel's massive immigration experience, especially from Russia in the 1990s, makes it a clear outlier. Lithuania, Latvia, and Estonia experienced large negative net immigration rates, as discussed above in more detail, due to ethnic Russians returning after the disintegration of the Soviet Union. This really was more of an emigration phenomenon in terms of the main characteristics and implications.

\footnotetext{
${ }^{20}$ The wage effect on highly educated non-migrants (available upon request) are sometimes negative and sometimes positive depending on whether the complementarity effects are stronger than the externality.
} 
The countries are listed in decreasing order of their total 1990-2000 immigration rates as defined in Table 1. A number of interesting features immediately become clear. First, all simulated values (with the exception of the low scenario for Austria) are positive, indicating that in almost every case, less educated native workers gained from immigration. For some countries with large immigration rates, such as Ireland, Canada, or Australia the gains for the natives are quiet high and range from 4-6\%. For other countries with intermediate levels of immigration, such as Belgium, the United Kingdom, and Switzerland the effects are also non-negligible at between 1 and $2 \%$. For most of the other countries, the estimates are negligible and are between 0 and positive $1 \%$. Second, the differences between the low and the high substitution scenarios illustrate the importance of the extent of nativeimmigrant substitutability and college externalities in determining the wage effects. The most pessimistic results are mainly driven by low elasticities of substitution between more and less educated workers and the absence of human capital externalities. Third, even though the US had high immigration rates, the less educated native workers experience one of the lowest wage effects with the estimated long-run effect running between $0.3 \%$ and $1.2 \%$.

The magnitude of the wage effect critically depends on the ratio of the highly educated to the less educated among the immigrants. Countries where laws explicitly favor more educated immigrants (such as Australia and Canada) experience larger positive effects both for the less educated natives as well as the total workforce. Other countries without such explicit laws (such as Ireland, UK, and Switzerland) also enjoy significant positive effects since they continue to attract a large portion of highly educated immigrants. On the other hand, if the skill composition of immigration flows is not biased in favor of the educated, then the net wage effect on the natives becomes quite small.

The economy-wide average wage effects in Figure 1.b mirror, qualitatively, the effects on the less educated natives as reported in Figure 1.a. However, they are quantitatively smaller and the relative differences between the scenarios are higher. In the low scenario (no externalities, perfect substitution between natives and immigrants, low complementarity between more and less educated and rigid labor supply), the net average wage effects are very close to 0 for almost every country.

Countries to the right of Turkey, which include most Eastern European and Asian countries in our sample, received quite low immigration flows at generally less than $1 \%$ of their labor force during the whole decade. As expected, therefore, the wage effects are also small. Still, except for Poland which experienced negative net immigration, the effects were positive for both the overall labor force and the less educated. Countries located between Turkey and Spain experienced intermediate immigration rates (between 1\% and 3.5\%) and they all had positive wage effects that range between $0 \%$ to $2 \%$ for the less educated and between $0 \%$ and $1.5 \%$ for the average worker.

\subsection{Employment effect of immigration}

Using expressions (18) and (17), we are able to evaluate long-run effects of immigration on native employment levels. The main results for each country in our sample are shown in Figures 2.a (for the less educated) and 2.b (for the labor market as a whole). The overall effects tend to be small as the elasticity of labor supply is relatively low in the aggregate, with the largest value set at 0.2 . The general patterns of the employment effects are similar to those of 
the wages from the previous section since they are also driven by increases (or decreases) in the marginal productivity of non-migrant workers due to changes in the immigration levels. There is an interesting additional effect, driven mainly by complementarities in the model. If immigration flows are skill intensive, as it is the case in most of the destination countries in our sample, then the less educated natives benefit from the complementarities generated by the increase in the relative share of the highly educated in the labor force. As a result, their employment levels increase, which in turn, further benefits the productivity levels of the college educated and so on. This mechanism, however is quite limited within the range of our simulations since the labor supply is not very elastic.

Figure 2.a shows the employment effects for the less educated and Figure 2.b for aggregate non-migrant native employment. The Figures replicate the structure and the notation of Figures 1.a and 1.b. In the "high" scenario (see Table 3 for the parameter values), the labor supply is inelastic, so that we observe the largest impact on wages. Hence, by assumption, the employment effect of immigration is 0 . In the intermediate scenario, the value of the labor elasticity is 0.1 and in the "low" scenario, the labor supply elasticity has the largest value at 0.2 . In this last case, the transmission from changes in marginal productivity to employment is the largest.

While the qualitative features of employment effects (sign and relative magnitude across countries) are similar to the wage effects, their magnitude is much smaller. The largest effects we observe are around $+0.7 \%$ in the low scenario for the less educated natives in the largest migrant receiving countries like Ireland, Australia, and Canada. We should note that these were countries where the wage effect was also the largest. Again, Austria is the only country to have a negative effect (a very small -0.05\%) on employment of less educated workers in the low scenario. Eastern European countries and others, located toward the right hand side of the graph, that have minimal immigration, also experience minimal impact on employment levels as expected. The employment effects in the overall labor force (Figure 2.b) are smaller - as it was the case for the wage effects - but show the same qualitative patterns. Large migrant receiving countries have the largest positive effect (at the maximum level of $0.3 \%$ ) and the rest of the countries experience effects below $0.1 \%$.

\subsection{Wage effects of emigration}

Our data show that net emigration rates for some of the OECD countries were at least as large as net immigration rates during the considered period, in particular for collegeeducated workers. While the literature almost exclusively focuses on the labor market effects of immigration, one of the main contributions of this paper is the analysis of the wage impact of these emigration flows, modeling them as a decline in the supply of native workers.

Figure 3.a shows the effects of the observed emigration patterns on the wages of less educated non-migrant native adults in their countries of origin. Figure 3.b shows the same effect on the average non-migrant wages. (The actual numerical values presented in these figures for each scenario and each country are listed in Table A6 of the appendix.) The countries are now listed from left to right in decreasing order of the ratio of the collegeeducated individuals among the emigrants, as shown in Table 2 above. Focusing on Figure 3.a, the most striking observation is that the wage impact is opposite of what is seen in the previous section on the effects of immigration. Net emigration involves a larger percentage 
decline of college educated workers and costs native less educated workers up to $6 \%$ of their wage income in several OECD countries and more than $1 \%$ in many others. In countries with large emigration rates (such as Cyprus, Malta, Ireland, New Zealand, and Portugal) the impact on wages of less educated natives is negative and sometimes quite large. The range is between $-1 \%$ (Portugal) and around $-6 \%$ (Ireland and Cyprus depending on the elasticity scenario). Even at intermediate rates of emigration, some countries still experience negative effects of around -1\% (e.g. Latvia, South Korea, United Kingdom, and Canada). In all cases, however, less educated workers do not gain as a consequence of emigration. The losses are due to the foregone complementarity effects and lost externalities from departure of the college educated individuals. Even the average wage losses, shown in Figure 3.b, are relatively large (between 1 and 3\%) in the same four countries (Cyprus, Malta, Ireland and New Zealand) and between 0 and $1 \%$ in most others. While some of the countries that experience negative effects from emigration (such as Ireland and the UK) manage to offset these effects, partially or totally, with the positive effects of immigration, many others fail to do so. The simulation results presented lead us to think that the main losses for the less educated workers in OECD countries arise from the loss of externalities that disappear with the departure of highly educated natives to other countries, rather than the arrival of foreign born immigrants. This is in stark contrast to the common public perception.

\section{Extensions}

The analysis of the wage effects of immigration on less educated natives can still be viewed as somewhat optimistic. First, our database may not fully capture undocumented immigration to the OECD countries, which is widely believed to include a larger proportion of less educated workers. Second, it assumes that highly educated immigrants are homogeneous and possess the same level of human capital as native highly educated workers in the destination labor markets. Third, it does not isolate the most controversial part of immigration, which is that from poor countries. Fourth, it considers data from the 1990's which misses the recent large immigration flows from North Africa and the Middle East to Europe, and from Central America to the US. These recent immigrant cohorts are also believed to be less educated. Finally, our simulations focus on the long-run effects, while one could argue that slow capital adjustment can result in a negative wage impact in the short run. In this section we tackle all of these issues.

\subsection{Undocumented immigrants and skill downgrading}

The census data are the primary sources used to construct our stocks of immigrants. Yet national censuses vary in their ability of measuring undocumented immigration due to a variety of legal, economic, and political reasons. In some countries, such as the United States and Canada, the coverage of the resident population should be complete and hence include (possibly with some small underestimates in the order of 10\%) the undocumented immigrant population. In other countries, such as many in continental Europe, the censuses have a harder time in properly counting the undocumented immigrants. Several countries in Europe recently joined forces for the "Clandestino" study (European Union, 2010) which 
produced a picture of the undocumented population in 12 European Countries for the years between 2000 and 2007. The study used several methods including surveys, data from regularization laws and data on apprehension and expulsions of undocumented individuals, to produce estimates of the variable $p_{i}$, the fraction of undocumented in the total immigrant population of country $i$. We utilize these estimates, from around 2000 and we multiply the inflow of documented (measured) immigrants over the period 1990-2000 by $p_{i} /\left(1-p_{i}\right)$ to obtain a number of imputed undocumented immigrants. Then, in order to maximize the possible impact of undocumented immigration on our estimates, we assume that all undocumented immigrants were less educated and we add these imputed numbers to the corresponding groups in our database. Table A7 in the Appendix shows the upper and lower estimates for $p_{i}$ in all of the countries. For the European countries not covered by the study, we assign the $p_{i}$ of the closest country for which it is available. For non-European countries with a census system that covers all residents, we assume that undocumented individuals are included in our data. For Japan, South Korea, and Chile, for which we have no information, we set the upper and lower bound of $p_{i}$ to the average values in the sample. It is worth noting that only in Eastern European countries, Italy, and Greece, the upper-bound estimates of undocumented individuals reached values higher than $20 \%$ of the total immigrant population (e.g. 30\% in Czech Republic, 37\% in Poland, 23\% in Greece and 33\% in Italy). In all other European countries, the upper bound estimates were lower than 10\%. In particular, for the countries with the largest net inflows (Austria, Spain, and Ireland), the estimates ranged between 3 and 10\% only. This implies that correction for undocumented should not have a significant effect on the previous values.

A second reason to believe that we may be under-estimating the actual size of the unskilled immigrant population is due to "skill downgrading". As shown in several studies (such as Dustman et al., 2008 for the UK, Cohen-Goldner and Pasermann, forthcoming for Israel as well as Mattoo, Ozden and Neagu, 2008 for the US) immigrants with intermediate and high education tend to find jobs in occupations typically staffed by natives with lower level of schooling. Hence, the actual "human capital" supplied to the labor market might not be corresponding to those indicated by their schooling level as reported in the census data. By considering college-educated immigrants as fully equivalent to college-educated natives, we might be over-estimating their contribution to the ratio of highly educated in the labor force. In order to correct for this bias, we use information on the actual occupations in which immigrants and natives are employed, by level of schooling in different countries. The newly collected DIOC-E Database (OECD, 2010) covers 89 destination and 233 origin countries and contains information on the distribution of foreign-born immigrants across occupations (according to the ISCO-88 one-digit classification) by country of origin and schooling level for the year 2000. Following Mattoo et al. (2008), we consider college educated workers who are employed as managers, directors, senior officials, professionals, associate professionals, and associate managers as "highly skilled". These occupations include the one-digit codes 1, 2 and 3 in the ISCO-88 classification. Then, we measure the frequency of workers in these jobs among immigrants with college education $\left(f_{F H}\right)$, among less educated native workers $\left(f_{N L}\right)$, and among college educated native workers $\left(f_{N H}\right)$. Using these frequencies we decompose one highly educated immigrant worker into a linear combination of more and less educated native workers, so that the combination matches the probability of being in a highly skilled job. In particular, we consider one highly educated immigrant worker in country $i$ as 
equivalent to $\tau_{i}$ units of highly educated native worker and $\left(1-\tau_{i}\right)$ units of less educated native worker where $\tau_{i}$ solves the following equation: $\left(f_{F H}\right)_{i}=\tau_{i}\left(f_{N H}\right)_{i}+\left(1-\tau_{i}\right)\left(f_{N L}\right)_{i}$. In countries in which highly educated immigrants are as likely to be in highly skilled occupation as natives, we would expect $\tau_{i}=1$ so that highly educated immigrants are fully counted as college-equivalents. In countries in which highly educated immigrants have similar probability as less educated natives to be in a skilled occupation, we would expect $\tau_{i}=0$. Hence, highly educated natives are counted as "less educated" native equivalents. In all cases, we obtain $\tau_{i}>0{ }^{21}$. The estimates for $\delta_{i}$ by country are shown in Table A8. The countries suffering the largest downgrading of immigrants are Cyprus, Greece and Israel where each college educated immigrant is counted as around 0.6 college-equivalent natives.

Figures 4.a and 4.b show the simulated wage effects (on less educated and average) native workers once we account for undocumented immigrants and downgrading of their education levels using the methods described above. The thick solid line (both in Figures 4.a and 4.b) connects the values obtained using the intermediate parameter configuration (Table 3) and accounting for downgrading plus using the lower estimate for the share of undocumented workers. The thin solid line assumes the intermediate scenario and includes downgrading with high estimates of undocumented. The dashed line shows the low scenario with downgrading and high estimates of undocumented. The dashed line is really the most pessimistic scenario we can construct with our data. Immigrants are perfect substitutes for natives; there are no externalities; undocumented immigrants are all counted as less educated and a part of highly educated immigrants are counted as low skilled because of their occupations. Despite these extreme assumptions we see positive effects in every Country, with the usual exception of Austria. Less educated workers experience either no effect (such as the US, Denmark, Italy, and Greece) or positive effects (as large as 3-3.5\% in Ireland, Canada, and Australia). Similarly, for average wages, the effect is zero (or very close) in several countries in the worst-case scenario (dashed line). In the intermediate scenario, accounting for downgrading and undocumented still leaves wage gains for natives in the order of 0.5 to $1.5 \%$ for all countries with immigration rates at least as large as Spain. These corrections slightly attenuate the positive effects of the previous section but in most cases they do not cancel, let alone reverse, them.

\subsection{Immigration from non-OECD countries}

International mobility is not a phenomenon that pushes people mainly out of non-OECD into OECD countries as the new database reveals. Table 4 shows that the total foreignborn population in the OECD countries account for $7.7 \%$ of the resident population. Of this total, only $3.7 \%$ of the population was born outside the OECD while $4 \%$ was born in another OECD country. Still, as seen also in Table 4, 60\% of the net flow of international migrants to OECD countries during the period 1990-2000 came from outside the OECD. As a result, the general perception has become that the immigrants are less educated than natives, less adequate for highly skilled jobs, and they generate the most negative effects for less educated natives in the labor market.

\footnotetext{
${ }^{21}$ In several cases, Mexico, New Zealand, Poland and Romania, we obtain $\tau_{i}>1$. This implies that highly educated immigrants in those countries are more likely to do highly skilled jobs.
} 
In Figures 5.a and 5.b, we show the simulated effects on the wages of the less educated and average worker, considering only net immigration from non-OECD countries. The countries are listed from left to right in decreasing order of their immigration rates from non-OECD countries. Hence the order is quite different from Figure 1.a. Several European countries, such as Luxembourg and Ireland, rank much lower in this ranking when compared to the one for total immigration rates, because a very large fraction of their immigrants are from other European (OECD) countries. On the other hand, Canada, New Zealand, and Australia jump to the top (left) of the ranking. In terms of wage effects, however, the only country for which non-OECD immigrants appear to be quite different in their schooling distribution relative to OECD immigrants, thus implying different wage effects, is Luxembourg. While total immigration had a positive impact (1 to $3 \%$ ) on the less educated workers, non-OECD immigration has a smaller (possibly negative) effect between -0.10 and $-0.4 \%$. Canada, New Zealand, Australia, Ireland, and the UK experience a positive wage gain for less educated workers between 1 and 3\%, from non-OECD immigrants. Less educated natives in the US also experience a larger positive impact $(+0.5 \text { to } 1.0 \%)^{22}$ and only Austria, Luxembourg, Denmark, and Italy experience a very small $(-0.2$ to $-0.01 \%)$ wage loss from non-OECD immigration. Figures 6.a and 6.b show the effect of non-OECD immigration on wages, accounting for skill downgrading (using specific non-OECD-origin downgrading coefficients, $\tau_{i}$ ) and estimates for undocumented immigration. All wage effects are still very small or positive. Australia, Canada, New Zealand, the US, the UK, and Ireland experience positive effects larger than $0.5 \%$ for their less educated workers and larger than $0.2 \%$ for their average wages. The other countries experience effects between -0.1 and $0.5 \%$.

\subsection{Immigration in the 2000s}

The data used so far cover migration patterns in the 1990s. Only with the collection and dissemination of data from the 2010 censuses, the analysis of the last decade of migration for different education groups will be possible. The recent economic crisis, starting in 2007, reduced net immigration rates to OECD countries drastically according to preliminary data (e.g. Papademetriou et al. 2011 ). During the 2000-2007 period, some destination countries, especially in Europe (mainly Spain, Italy, Greece, and Ireland) experienced immigration rates even larger than the ones observed during the 1990s. Were these flows very different from the previous ones? Was their composition less college-intensive? Were their effects on wages comparable to those of the 1990-2000 flows? To answer these questions, we consider net immigration to 13 European countries for the period 2000-2007 plus immigration to the United States during the 2000-2009 period. The European Data are from the EU Labor Force surveys, that allow us to identify adults (older than 25) by education level, separating natives from foreign-born immigrants. ${ }^{23}$ For the US, we use the American Community Survey data on the same definition of natives and immigrants with different education levels. Table 5

\footnotetext{
${ }^{22}$ Recall that the group of immigrants to the US with the lowest share of college graduates are Mexicans, hence, an OECD country, while the group of immigrants with the largest share of college graduates are Indians, hence a non-OECD country.

${ }^{23}$ We thank Francesco D'Amuri for his help with the EULFS data.
} 
shows the immigration rates for the $2000-2007^{24}$ period for all the countries. We only included countries for which the database includes the years 2000 as well as 2007 and for which the relevant characteristics (age, education, and place of birth) had fewer than 10\% of missing observations. This restriction excluded the UK, Italy, and Ireland (among others). As we see in Table 5, the country with a real boom, relative to the previous decade, was Spain with an immigration rate of $11 \%$. Luxembourg, Austria, and the US, the other top destination countries in terms of rates, had lower rates than for the 1990's. As we are excluding the crisis period (post 2007) for the European countries, most will end up with even lower rates when the whole decade is considered. Figures 7.a and 7.b show the simulated native wage effects (for less educated and for the average, respectively) due to immigration 2000-2007. The countries are listed in decreasing order of total immigration rates for the 2000-2007 period. In most cases all specifications produce positive effects ranging from 0 to $2 \%$ in Figure 7 .a and between 0 and 1\% in Figure 7.b. Exceptions are Luxembourg, with potentially large positive effects on less educated wages (between 3 and 7\%) and Lithuania, which experienced negative net immigration (hence emigration of foreign residents) and suffered a 1-2\% wage loss for less educated. One specification (intermediate dashed line) includes the corrections for undocumented and downgrading which somewhat reduce the gains but do not change the overall picture.

\section{Conclusions}

Closing the borders to immigrants, restricting the inflow of people from poor countries, and making their entry more costly and difficult is sometimes presented by politicians as a way of protecting employment and wages of domestic workers, especially those at the bottom of the income distribution. This paper shows, using new aggregate data on migrations and a simple aggregate model that, because college educated individuals are much more mobile than other workers and they are likely to create opportunities for the receiving economy, immigration is likely to help native wages and employment. We show that, in the long-run, the wage and employment effects of immigration in the 1990s and in the 2000s were rather small and always positive for less educated workers of all OECD countries. Less educated workers in Canada, Australia, the US, Luxembourg, the UK, and Switzerland, which were among the magnets of international migrants, all experienced positive long-run effects from immigration, between 1 and $5 \%$, according to our calculations. To the contrary, emigration, which entails the loss of talent and brains in much larger proportion than the loss of unskilled workers, is the real threat for unskilled workers left behind, even in some OECD countries. Less educated workers in Cyprus, Malta, Ireland, New Zealand, and Portugal all lost between 1 and 6\% of their wages because of the flight of highly educated emigrants. While net emigration, especially of college educated individuals, may be a symptom of economic malaise and not its cause, it certainly directly contributes to lower productivity and wages of the remaining workers.

These results are surprising. Hence, we undertake a series of robustness checks. We use estimates of the undocumented immigrants to correct for their flows. Second, we account

\footnotetext{
${ }^{24}$ Immigration rates are calculated, as usual, as net immigrants during the period 2000-2007 divided by total residents in 2000.
} 
for the actual occupations of highly educated immigrants to correct for skill downgrading. Third, we consider only immigration from non-OECD countries, and fourth we restrict our attention to migration 2000-2007. Finally, we correct for the short-run sluggish capital adjustment. None of the corrections eliminates or reverses (although they somewhat attenuate) the findings of positive long-run effects of immigrants on wage and employment of less educated workers in all OECD countries. Only the short-run correction shows that, in the short run, a few countries (Spain and Cyprus) that received very large immigration flows during the period 2000-2007 (up to 11\% of their population) suffered small wage losses (up to $1.4 \%$ ). According to our simulations for the 2000 s, less educated workers in the US experienced no wage effects from immigrants in the short-run and a positive effect of up to $1.2 \%$ wage increase in the long-run. 


\section{References}

[1] Acemoglu, Daron, and Joshua Angrist (2000). "How large are human capital externalities? Evidence from compulsory schooling laws." NBER Macroeconomic Annual 15.

[2] Acemoglu, Daron, and Fabrizio Zilibotti (2001). "Productivity Differences." Quarterly Journal of Economics 116 (2): 563-606.

[3] Angrist, Joshua D. (1995). "The Economic Returns to Schooling in the West Bank and Gaza Strip." American Economic Review 85 (5): 1065-1087.

[4] Azariadis, Costas, and Allan Drazen (1990). "Threshold externalities in economic development." Quarterly Journal of Economics 105 (2): 501-526.

[5] Barro, Robert and Lee, Jong-Wha, 2010. "A New Data Set of Educational Attainment in the World, 1950-2010" NBER working paper 15902, data downloadable at: http://www.barrolee.com/

[6] Barro, Robert J. and Sala-i-Martin, Xavier, 2003. "Economic Growth, 2nd Edition," MIT Press Books, The MIT Press, edition 2, volume 1, number 0262025531, June.

[7] Benhabib, Jess, and Mark M. Spiegel (2005). "Human Capital and Technology Diffusion." In Ph. Aghion and S. Durlauf (eds.), Handbook of Economic Growth, Elsevier: Vol. 1, Chapter 13, 935-966.

[8] Borjas, George. 2003. "The Labor Demand Curve is Downward Sloping: Reexamining the Impact of Immigration on the Labor Market." Quarterly Journal of Economics 118, no. 4: $1335-1374$.

[9] Borjas, George, and Lawrence Katz. 2007. "The Evolution of the Mexican-Born Workforce in the United States." In: Borjas, George (Ed), Mexican Immigration to the United States National Bureau of Economic Research Conference Report, Cambridge, MA.

[10] Borjas, George, Jeffrey Grogger, and Gordon Hanson (2008). "Imperfect Substitution between Immigrants and Natives: A Reappraisal." National Bureau of Economic Research, Working Paper \# 13887, Cambridge, MA.

[11] Card, David. (2001). "Immigrant Inflows, Native Outflows, and the Local Labor Market Impacts of Higher Immigration." Journal of Labor Economics 19, no 1: 22-64.

[12] Card, David (2009). "Immigration and inequality." American Economic Review 99 (2): $1-21$.

[13] Card, David, and Thomas Lemieux (2001). "Can Falling Supply Explain the Rising Returns to College for Younger Men? A Cohort Based Analysis." Quarterly Journal of Economics 116 (2): 705-746.

[14] Caselli, Francesco, Gerardo Esquivel, and Fernando Lefort. 1996." Reopening the Convergence Debate; A New Look at Cross-Country Growth Empirics." Journal of Economic Growth 1, no.3: 363-389. 
[15] Caselli, Francesco, and Wilbur Coleman (2006). "The World Technology Frontier." American Economic Review 96 (3): 499-522.

[16] Ciccone Antonio and Giovanni Peri (2005) "Long-Run Substitutability between More and Less Educated Workers: Evidence from U.S. States 1950-1990" Review of Economics and Statistics, Vol. 87, Issue 4, pages 652-663.

[17] Ciccone Antonio and Giovanni Peri (2006) "Identifying Human Capital Externalities: Theory with Applications" Review of Economic Studies, Vol. 73, pp. 381-412.

[18] European Union (2009) “ Clandestino Project 2007-2009”, http://clandestino.eliamep.gr/project-results/

[19] Cohen, Daniel, and Marcelo Soto (2007). "Growth and human capital: Good data, good results". Journal of Economic Growth 12 (1): 51-76.

[20] Cohen-Goldner, Sarit and Daniele Paserman (forthcoming) "The dynamic impact of immigration on native's labor-market outcomes: Evidence from Israel" forthcoming in the European Economics Review.

[21] D'Amuri, Francesco, Gianmarco I.P. Ottaviano, and Giovanni Peri (2010). "The labor market impact of immigration in Western Germany in the 1990s." European Economic Review 54, 550-570.

[22] De la Fuente,A.,\&Domenech, R. (2006) "Human capital in growth regression: How much difference does quality data make?" Journal of the European Economic Association, $4(1), 1-36$.

[23] Docquier, A. Marfouk (2006) "International Migration, Remittances and Development" in C. Ozden and M. Schiff (eds). Palgrave Macmillan: New York.

[24] Docquier, Frédéric, B. Lindsay Lowell, and Abdeslam Marfouk (2009). "A gendered assessment of highly skilled emigration." Population and Development Review 35 (2): 297-321.

[25] Docquier, Frédéric, Abdeslam Marfouk, Caglar Ozden, and Christopher R. Parsons (2010). "Geographic, gender and skill structure of international migration." Report written for the Economic Research Forum.

[26] Dustmann, Christian, Tommaso Frattini and Ian Preston (2008). "The Effect of Immigration along the Distribution of Wages," Discussion Paper Series 0803, Centre for Research and Analysis of Migration (CReAM), Department of Economics, University College London.

[27] Flood, L. and T. MaCurdy (1992), 'Work Disincentive Effects of Taxes: An Empirical Analysis of Swedish Men" Carnegie-Rochester Conference Series on Public Policy, 37, pp. 239-278. 
[28] Freeman R. (2006) "People Flows in Globalization" Working Paper \# 12315, National Burau of Economics Research, Cambridge, Mass, April 2006.

[29] Friedberg Rachel (2001) "The Impact of Mass-Migration on the Israeli Labor Market" The Quarterly Journal of Economics, Vol. 116 n.5 pp. 1373-1408.

[30] Goldin, Claudia and Larry Katz (2008). "The Race Between Education and Technology." Harvard University Press, Cambridge, MA, 2008.

[31] Grogger, Jeffrey and Gordon Hanson (2011) "Income Maximization and the Selection and Sorting of International Migrants." Journal of Development Economics, 95, 1 (2011): 42-57.

[32] Hendricks, Lutz (2004). "A Database of Mincerian Earnings Regressions." www.lhendricks.org/Mincer.htm

[33] Islam, Nasrul. 1995. "Growth Empirics: A Panel Data Approach." Quarterly Journal of Economics 110, no.4: 1127-1170.

[34] Iranzo, Susana, and Giovanni Peri (2009). "Migration and Trade: Theory with an Application to the Eastern-Western European Integration." CReAM Discussion Paper Series 0905 .

[35] Johnson, George E. (1970). "The Demand for Labor by Educational Category." Southern Economic Journal, 37: 190-203.

[36] Katz, Larry, and Kevin Murphy (1992). "Changes in Relative Wages 1963-1987: Supply and Demand Factors." Quarterly Journal of Economics 107 (1): 35-78.

[37] Kerr, Sari Pekkala and Kerr, William (2009) "Economic Impact of Immigration: A Survey" Harvard Business School Working Paper, 09-13.

[38] Krusell Per, Lee E. Ohanian, José-Victor Rios-Rull and Giovanni L. Violante (2000). "Capital-Skill Complementarity and inequality: A Macroeconomic Analysis." Econometrica 68: 1029-53.

[39] Lucas, Robert E.J. (1988). "On the mechanics of economic development." Journal of Monetary Economics 22 (1), 3-42.

[40] Manacorda Marco, Alan Manning, and Jonathan Wadsworth (forthcoming). "The Impact of Immigration on the Structure of Wages: Theory and Evidence from Britain." forthcoming in the Journal of the European Economic Association.

[41] Mattoo, Aaditya, Ileana Cristina Neagu and Caglar Ozden (2008). "Brain waste? Educated immigrants in the US labor market." Journal of Development Economics 87 (2): 255-69.

[42] Moretti, Enrico (2004a). "Estimating the Social Return to Higher Education: Evidence from Longitudinal and Repeated Cross-Sectional Data." Journal of Econometrics 121 (1), 175-212. 
[43] Moretti, Enrico (2004b). "Workers' Education, Spillovers and Productivity: Evidence from Plant-Level Production Functions" American Economic Review 94 (3), 656-690.

[44] Murphy Kevin M., W. Craig Riddle, and Paul M. Romer (1998). "Wages, Skills and Technology in the United States and Canada." In: E. Helpman (Ed), General Purpose Technology and Economic Growth, Cambridge, MA, MIT Press.

[45] OECD (2010) "Database on Immigrants in OECD and non-OECD countries", release 2.0, Dec. 2010, http://www.oecd.org/document/33/0,3746,en_2649_37415_46561249_1_1_1_37415,00.html

[46] OECD (2011). "Society at a Glance, 2011." OECD Social Indicators, Paris, 2011.

[47] Ottaviano, Gianmarco I.P., and Giovanni Peri (forthcoming). "Rethinking the effects of immigration on wages." Journal of the European Economic Association (forthcoming).

[48] Ozden, Caglar, Christopher R. Parsons, Maurice Schiff and Terry Walmsley (2010). "The evolution of global bilateral migration 1960-2000." Paper presented at the second Migration and Development Conference. September 2009: Washington DC.

[49] Papademetriou G.P., M. Sumption and A. Terrazas (2011) "Migration and the Great recession. The Transatlantic Experience" Migration Policy Institution, Washington D.C.

[50] Peri, Giovanni (2011) ] "Rethinking the Area Approach: Immigrants and the Labor Market in California, 1960-2005" Journal of International Economics, Vol. 84 (1) pp. $1-14$.

[51] Ramsey, Frank. 1928. "A Mathematical Theory of Saving." Economic Journal 38 (152): 543-559.

[52] Romer, David. 2006. "Advanced Macroeconomics." McGraw-Hill, Third Edition. New York, NY.

[53] Saint-Paul, Gilles (2008). "Brain Drain: Some Evidence from European Expatriates in the United States." CESifo Forum, Ifo Institute for Economic Research at the University of Munich, vol. 9(3), pages 19-27, October.

[54] Solow, Robert. 1956. "A Contribution to the Theory of Economic Growth." Quarterly Journal of Economics 70 (1): 65-94.

[55] van Soest, A., I. Woittiez and A. Kapteyn (1990), "Labor Supply, Income Taxes, and Hours Restrictions in the Netherlands." Journal of Human Resources, 25, pp. 517-558.

[56] Vandenbussche, Jérôme, Philippe Aghion, and Costas Meghir (2006). "Growth, Distance to Frontier and Composition of Human Capital." Journal of Economic Growth 11 (2): $97-127$. 


\section{A Data details}

The migration data presented in Section 3 follow Docquier et al. (2010) who construct comprehensive 195x195 matrices of bilateral migration stocks. These matrices cover the two skill groups (college graduates and less educated individuals), and two years (1990 and 2000). Migration is defined on the basis of country of birth which is time invariant (contrary to the concept of citizenship, which changes with naturalization) and independent of the changes in policies regarding naturalization. However, this definition does not account for whether education has been acquired in the home or in the host country. This induces a potential over-estimation of the intensity of the brain drain migration of children and students can represent an important fraction of total immigration for certain countries. ${ }^{25}$

The methodology is described in detail in Docquier et al. (2010) and it consists of three main steps. The starting point (step 1) is the database described in Docquier, Lowell and Marfouk (2009), documenting bilateral migration stocks in OECD host countries. It is based on a collection of census and register immigration data by country of birth and educational level in the 30 OECD countries in 1990 and 2000. This OECD set of destinations does not include the three member states which joined the OECD in 2010 (Chile, Israel, and Slovenia) and future members (Estonia and Russia). This database characterizes the education level, origin and destination of about 57.4 million migrants in 2000 and 40.8 million migrants in 1990. High-skill migration represents 35.4 percent of the total in 2000 (30.1 percent in 1990). The second step consists of a collection of similar immigration data from 46 nonOECD destinations in 2000 and 31 destinations in 1990. In the third step, data collected in steps 1 and 2 are used to estimate the determinants of the size of bilateral migration $\left(M_{i j t}^{s}\right)$ from country $i$ to country $j$ in the education group $s$ at year $t$. Then, based on these estimations, the size of the migrant stock from each origin country to the remaining 119 non-OECD host countries in 2000 (and 134 in 1990) for each education level is predicted. The final 195x195 database combines recorded migration stocks (when census and register data are available) and out-of-sample predictions (when official statistics are missing).

Table A1 provides summary statistics for migration stocks which are comparable with labor force data. The database characterizes the origin, destination and education level of about 100.5 million adult migrants in 2000, and 80.2 million in 1990. Table A2 distinguishes observed and imputed values for immigrants to countries included in our sample. Table A3 shows stock of immigrants and emigrants in 1990 and 2000 as percentage of the skill-specific labor force. Table A4 describes the distribution of the labor force between college graduates and less educated as percentage of total.

\footnotetext{
${ }^{25}$ Beine et al (2007) have estimated the age-of-entry structure of high-skill immigration and proposed alternative measures of the brain drain excluding those who left their home country before age 12,18 or 22 . The corrected rates are obviously lower than those calculated without age-of-entry restrictions. However, the correlation between corrected and uncorrected rates is extremely high and the country rankings by brain drain intensities are basically unaffected by the correction. This should mitigate concerns about child migration possibly leading to cross-sectional biases in the brain drain estimates.
} 


\section{B Derivation of the marginal productivity effect}

Taking the logarithmic total differential of (7) and (8) with respect to infinitesimal variations of each type of labor we obtain the following expressions:

$$
\begin{gathered}
\frac{\partial \ln w_{i, n}}{\partial w_{i, n}} \Delta w_{i, n}= \\
\frac{1}{\sigma_{q}}\left(\frac{\partial q}{\partial q_{h, f}} \frac{\Delta q_{h, f}}{q}+\frac{\partial q}{\partial q_{l, f}} \frac{\Delta q_{l, f}}{q}+\frac{\partial q}{\partial q_{h, n}} \frac{\Delta q_{h, n}}{q}+\frac{\partial q}{\partial q_{l, n}} \frac{\Delta q_{l, n}}{q}\right)+ \\
\left(\frac{1}{\sigma_{m}}-\frac{1}{\sigma_{q}}\right)\left(\frac{\partial q_{i}}{\partial q_{i, f}} \frac{\Delta q_{i, f}}{q_{i}}+\frac{\partial q_{i}}{\partial q_{i, n}} \frac{\Delta q_{i, n}}{q_{i}}\right)-\frac{1}{\sigma_{m}} \frac{\Delta q_{i, n}}{q_{i, n}}+\lambda \Delta f_{h} \text { for } i=(h, l)
\end{gathered}
$$

The equilibrium condition ensures that each type of labor is paid its marginal productivity. Moreover, labor is the only production factor, and hence we can write:

$$
s h_{i, j}=\frac{w_{i, j} q_{i, j}}{y}=\frac{\partial y}{\partial q_{i, j}} \frac{q_{i, j}}{y}=\frac{\partial q}{\partial q_{i, j}} \frac{q_{i, j}}{q}
$$

Hence, using the result in (24) and multiplying $s h_{i, j}$ by $\Delta q_{i, j} / q_{i, j}$ we obtain exactly each of the four terms in the first round bracket of (23) and we can transform them into their corresponding terms in (9). Similarly, using the expression for wages we can show that:

$$
\frac{s h_{i, n}}{s h_{i}}=\frac{w_{i, n} q_{i, n}}{w_{i, n} q_{i, n}+w_{i, f} q_{i, f}}=\theta_{i} q_{i, n}^{\frac{\sigma_{m}-1}{\sigma_{m}}} q_{i}^{\frac{1-\sigma_{m}}{\sigma_{m}}}=\frac{\partial q_{i}}{\partial q_{i, n}} \frac{q_{i, n}}{q_{i}}
$$

and

$$
\frac{s h_{i, f}}{s h_{i}}=\frac{w_{i, f} q_{i, f}}{w_{i, n} q_{i, n}+w_{i, f} q_{i F}}=\theta_{i} q_{i, f}^{\frac{\sigma_{m}-1}{\sigma_{m}}} q_{i}^{\frac{1-\sigma_{m}}{\sigma_{m}}}=\frac{\partial q_{i}}{\partial q_{i, f}} \frac{q_{i, f}}{q_{i}}
$$

which would allow to transform the terms in the second brackets in (24) into the corresponding expression of (9).

\section{Imperfect physical capital adjustment and short-run effects}

Another extension is to account for sluggish capital adjustment in the short-run (rather than assuming perfectly elastic capital supply), using estimates of the speed of adjustment from the literature. Below, we explain how capital sluggishness can be accounted for in the model, and present short-run effects.

Theory With full capital adjustment to its balanced growth path equilibrium the effects of migration on wages are as described above. However, immigration in the short run may affect the capital labor ratio $^{26} \kappa_{t}=k_{t} / q_{t}$ pushing the economy outside its balanced growth

\footnotetext{
${ }^{26}$ We use the slightly modified expression for the capital-labor ratio that includes the labor composite (rather than employment) in the denominator.
} 
path. Due to slow adjustment of capital there will be an extra effect of immigrants on marginal productivity of each type of worker, through $\kappa_{t}$. We can re-write the expressions of marginal productivity in (7) and (8) noting explicitly their dependence on the capital-labor ratio:

$$
\begin{aligned}
w_{h, t} & =\theta_{q} \theta_{h} \widetilde{A}_{t}\left(\kappa_{t}\right)^{1-\alpha}\left(\frac{q_{t}}{q_{h, t}}\right)^{\frac{1}{\sigma_{q}}}\left(\frac{q_{h, t}}{q_{h, n, t}}\right)^{\frac{1}{\sigma_{m}}} \\
w_{l, t} & =\left(1-\theta_{q}\right) \theta_{l} \widetilde{A}_{t}\left(\kappa_{t}\right)^{1-\alpha}\left(\frac{q_{t}}{q_{l, t}}\right)^{\frac{1}{\sigma_{q}}}\left(\frac{q_{l, t}}{q_{l, n, t}}\right)^{\frac{1}{\sigma_{m}}}
\end{aligned}
$$

On the balanced growth path (or in an open economy) the capital-labor ratio is constant and given by the following expression $\kappa_{t}^{*}=\left(\frac{1-\alpha}{R^{*}}\right)^{\frac{1}{\alpha}} \widetilde{A}_{t}^{\frac{1}{\alpha}}=\kappa^{*}$ : it does not depend on the inflows and outflows of migrants. In that case expressions (25) and (26) reduce to (7) and (8) and the total percentage effect of immigrants and emigrants on marginal productivity are as in (15) and (16). In the short run, however, $\kappa_{t}$ may deviate from its long-run equilibrium due to exogenous migration shocks. In this case the percentage effect on marginal productivity, included in expressions (17) and (18) of each group, includes an extra term, namely:

$$
\widehat{w}_{i, n, t(\text { short run })}^{m}=\widehat{w}_{i, n}^{m}+(1-\alpha) \widehat{\kappa}_{t(\text { short run })} i=(h, l)
$$

where $\widehat{\kappa}_{t \text { (short run) }}$ is the short-run percentage deviation of the capital-labor ratio from $\kappa^{*}$ due to exogenous immigration or emigration. Considering immigration ${ }^{27}$, with immediate and full capital adjustment, $\widehat{\kappa}_{\text {short run }}$ equals 0 . At the opposite extreme, with fixed total capital, $k_{t}=\bar{k}$, then $\widehat{\kappa}_{t \text { (short run) }}$ is approximately equal to the negative percentage change of labor supply due to exogenous immigration and emigration which is: $-\frac{\Delta Q_{h, f}+\Delta Q_{l, f}}{Q}$, where the numerator is the net change in workers due to the total net immigration and $Q$ is, approximately, the employment at the beginning of the period. While for short periods or for sudden shocks the short run effect may be evaluated considering capital as fixed in the case of ten years of immigration, which is a slow and sustained phenomenon, we need to account explicitly for the dynamics of the capital-labor ratio to recover a short-run effect.

A popular way to analyze the deviation of $\ln \left(\kappa_{t}\right)$ from its balanced growth path trend, used in the growth and business cycle literature, is to represent its time-dynamics in the following way:

$$
\ln \left(\kappa_{t}\right)=\beta_{0}+\beta_{1} \ln \left(\kappa_{t-1}\right)+\beta_{2}(\text { trend })+\gamma \frac{\Delta \overline{Q_{H, F}}+\Delta \overline{Q_{L, F}}}{Q_{t}}+\varepsilon_{t}
$$

where the term $\beta_{2}$ (trend) captures the balanced growth path trajectory of $\ln \left(\kappa_{t}\right)$, equal to $\frac{1}{\alpha} \ln \left(\frac{1-\alpha}{R^{*}} \widetilde{A}_{t}\right)$, and the term $\beta_{1} \ln \left(\kappa_{t-1}\right)$ captures the sluggishness of yearly capital adjustment. The parameter $\left(1-\beta_{1}\right)$ is commonly called the "speed of adjustment" since it is the

\footnotetext{
${ }^{27}$ The short run effect of exogenous emigration could be accounted similarly. The difference is that in that case we should consider actual, rather than exogenous, employment changes. However, in our case, due to the small values of net emigrants (relative to the total lab or force), we neglect the endogenous employment response on $\kappa$ in the short-run and we consider only the effect of exogenous emigration on it.
} 
share of the deviation from the balanced growth path (trend) eliminated each year. Finally, $\frac{\Delta Q_{h, f}+\Delta Q_{l, f}}{Q}$ represents the yearly net exogenous immigration flows as share of the labor force and $\varepsilon_{t}$ are other zero-mean uncorrelated shocks. Once we know $\beta_{1}, \gamma$ and the sequence of yearly net immigration flows, $\frac{\Delta Q_{h, f}+\Delta Q_{l, f}}{Q}$, we can use (28) to obtain an impulse response of $\ln \left(\kappa_{t}\right)$ as of 2000 in deviation from its trend (short run).

In order to obtain the short-run effect on native employment and wages of immigration we need to evaluate the yearly short-run deviation of $\ln \left(\kappa_{t}\right)$ from its trend due to the net inflows of immigrants $\frac{\Delta Q_{h, f}+\Delta Q_{l, f}}{Q}$ and correct the marginal productivity effects in by (1$\alpha) \widehat{\kappa}_{t \text { (short run) }}$. When analyzing the short-run effects of immigration it is reasonable to consider the labor supply as rigid, to be consistent with the optimizing model (which has a rigid labor supply) and to isolate only this channel.

Simulations For the immigration of the 1990s it is likely that only long-run effects are left. For the immigration during 2000-2007 there may still be some short-run effects, due to incomplete capital adjustment, embodied in the current wages. Hence, we use equation (27) to correct for the short-run impact on marginal productivity of changes in the capital-labor ratio. We also use equation (28) to calculate the actual deviation of $\kappa_{t}$ from the balanced growth path as a consequence of immigration. To implement (28) we need an estimate of the speed of convergence of capital. The recent growth literature usually estimates a $10 \%$ speed of convergence of capital to the own balanced growth path for advanced (OECD) economies (Islam, 1995; Caselli et al., 1996), implying $\beta_{1}=0.9$. and $\gamma=-0.9$ in equation (28) which are the values that we choose ${ }^{28}$.

We use the immigration rates over 2000-2007 period for the considered countries, and assume a uniform distribution of migration flows over the seven years. We adopt as parameters of capital adjustment $\beta_{1}=0.9$ and $\gamma=-0.9$ (assuming that capital adjustment begins the same year as immigrants are received). Hence the recursive equation (28) allows us to calculate $\widehat{\kappa_{t}}$ as of year 2010. Using formula (27) we adjust the marginal productivity effect and we include it in (19) to evaluate the short-run wage effects ${ }^{29}$. Figures A.1.a and A.1.b show the simulated wage effects, using the intermediate parameter scenario. The figure includes the previously estimated effects with constant interest rate (thick solid line), the effect after correcting for downgrading and undocumented (thin solid line) and the short-run effects (evaluated as of year 2010) obtained after correcting for capital adjustment (dashed line).

The short-run correction is larger the larger is the total immigration rate. Hence, its importance is decreasing as we move from left to right in the graph. The short-run wage effect on less educated is around $-1.4 \%$ for Spain and $-1.9 \%$ for Cyprus. Most of the other effects are very small (less than half a percentage point), while for Luxembourg the positive effect still dominates. So, even in the short run, less educated experience growth in wages of more than $2 \%$. For the United States the short run effect on wages of less educated natives is 0 .

\footnotetext{
${ }^{28}$ The business cycle literature calculates the speed of convergence of capital to be between 10\% and $20 \%$ in each year (Romer, 2006, Chapter 4) for closed economies, and even faster rates for open economies.

${ }^{29}$ Consistently with short-run analysis we consider rigid labor supply.
} 


\section{Tables and Figures}

\section{Figures:}

1. Immigration $1990-2000$ and wage of native workers

2. Immigration $1990-2000$ and employment of native workers

3. Emigration $1990-2000$ and wage of native workers

4. Wage effects of immigration 1990-2000, accounting for undocumented and downgrading

5. Wage effects of non-OECD immigrants 1990-2000 on native workers

6. Wage effects of non-OECD immigrants 1990-2000, accounting for undocumented and downgrading

7. Wage effects in 2000-2007 total immigration on native workers

A1. Short-run wage effects of 2000-2007 immigration, with undocumented and downgrading

\section{Tables:}

1. Immigration rates $1990-2000$

2. Emigration rates, total and for college graduates

3. Parameter values in the difference scenarios

4. Foreign-born in aggregate OECD countries

5. Immigration rates $2000-2007$ for a sample of EU countries and the US

A1. Immigration stocks aged 25+ in 1990 and 2000 (in millions)

A2. Stock of emigrants in 1990 and 2000 (x 1,000): observed and imputed values

A3. Wage income share of each group

A4. Simulated effects of immigrants on wages of less educated and average wages of natives

A5. Simulated employment effects of immigration

A6. Simulated wage effects of emigration

A7. Estimates of share of undocumented immigrants, by country as of 2000

A8. Estimates of the downgrading factors, based on occupations, for highly educated immigrants, by country, as of 2000 
Figure 1: Wage effects of total immigration 1990-2000 on native workers

(Countries ranked left-to-right by immigration rate)

1.a. Percentage effects of total immigration on less educated native wages

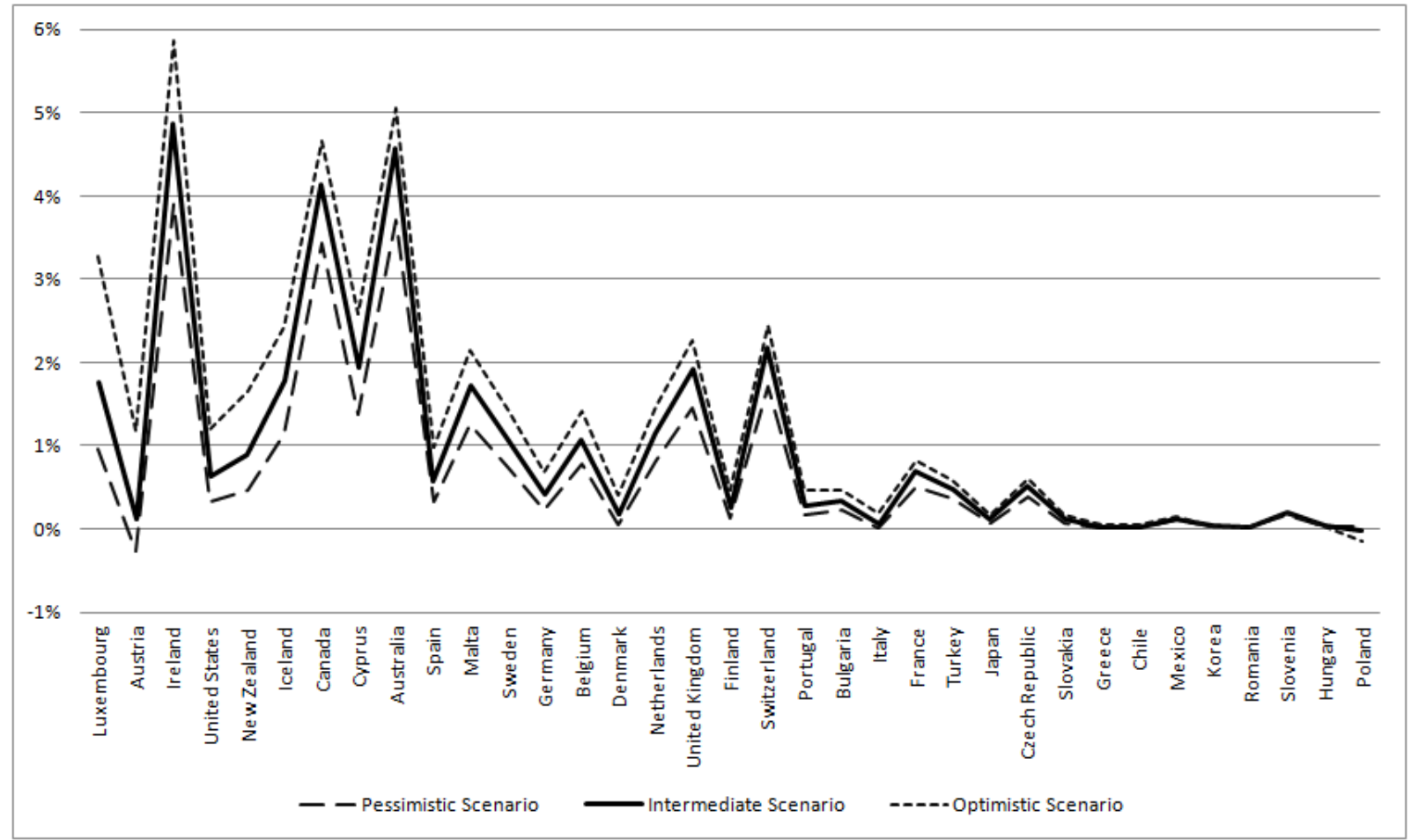

1.b. . Percentage effects of total immigration on average native wages

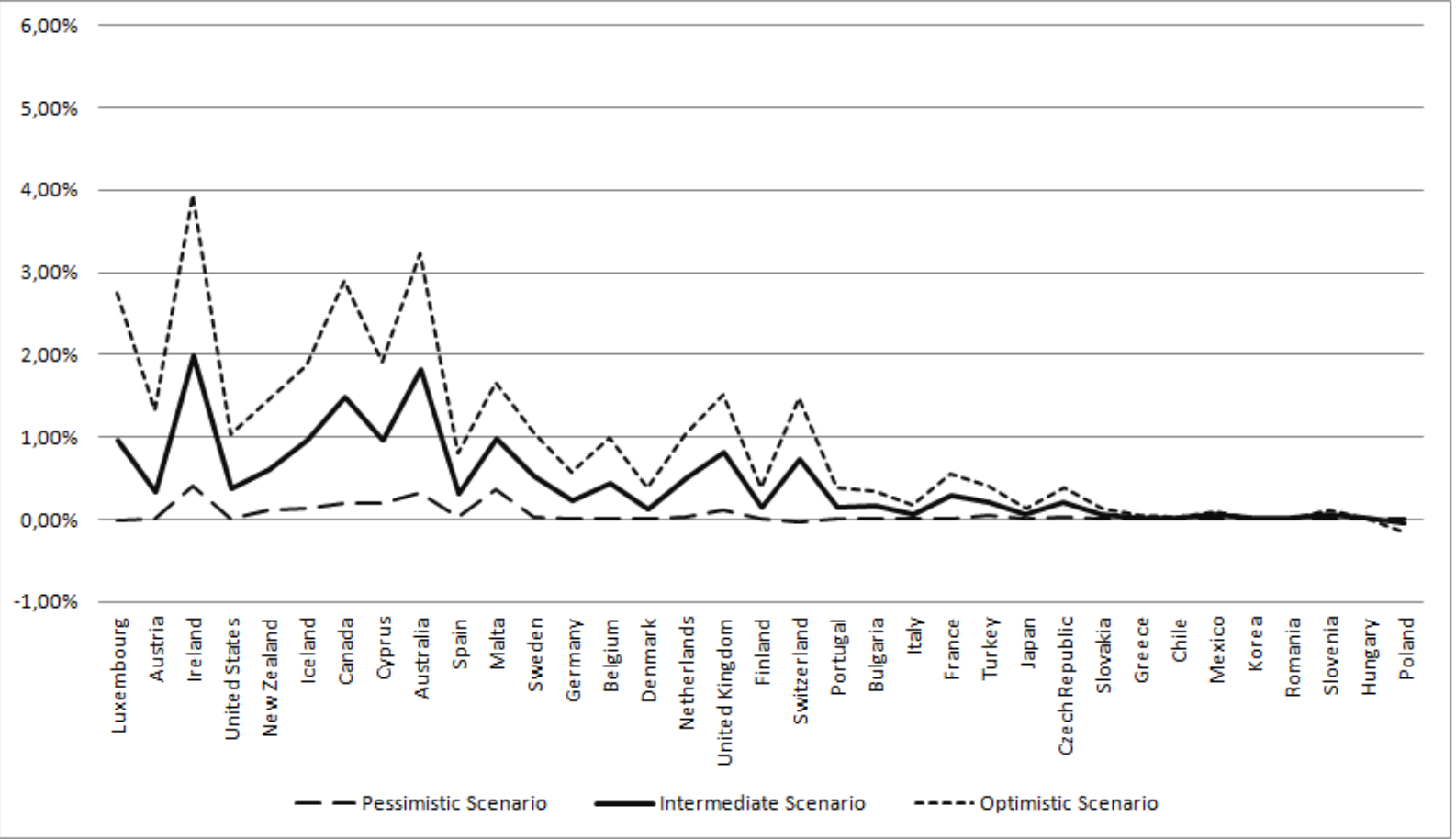

Note: Values on the vertical axis are the simulated wage effect (in percentage of the initial wage) of immigration on natives. We omit Israel and Lithuania, Latvia and Estonia from the chart as they are outliers (see Table A4). The parameter values corresponding to the "Pessimistic", "Intermediate" and "Optimistic" scenarios are reported in Table 4. 
Figure 2: Employment effects of total immigration 1990-2000 on native workers

(Countries ranked left-to-right by immigration rate)

2.a. Percentage effects of total immigration on employment of less educated natives

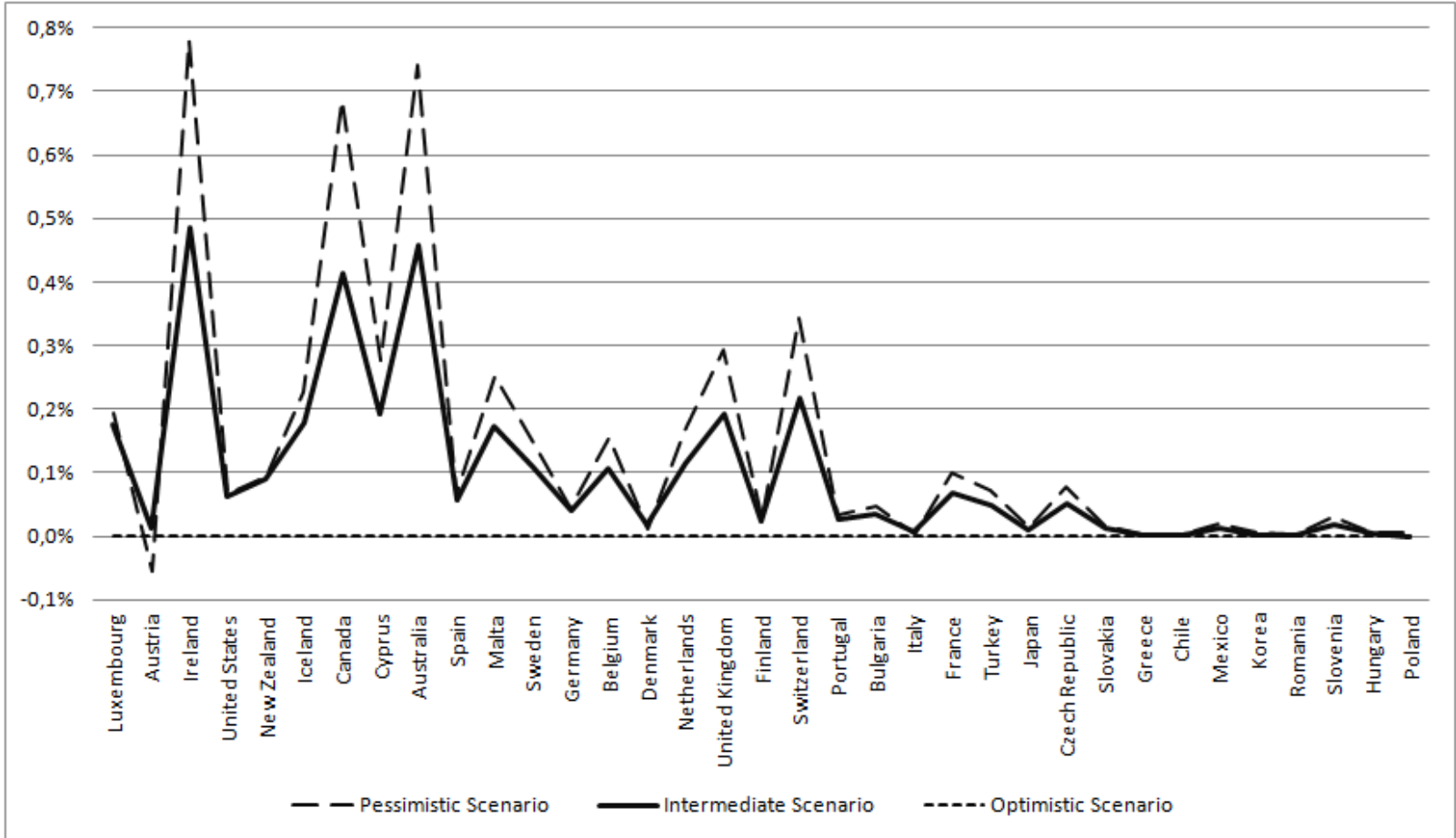

2.b. Percentage effects of total immigration on employment of all natives

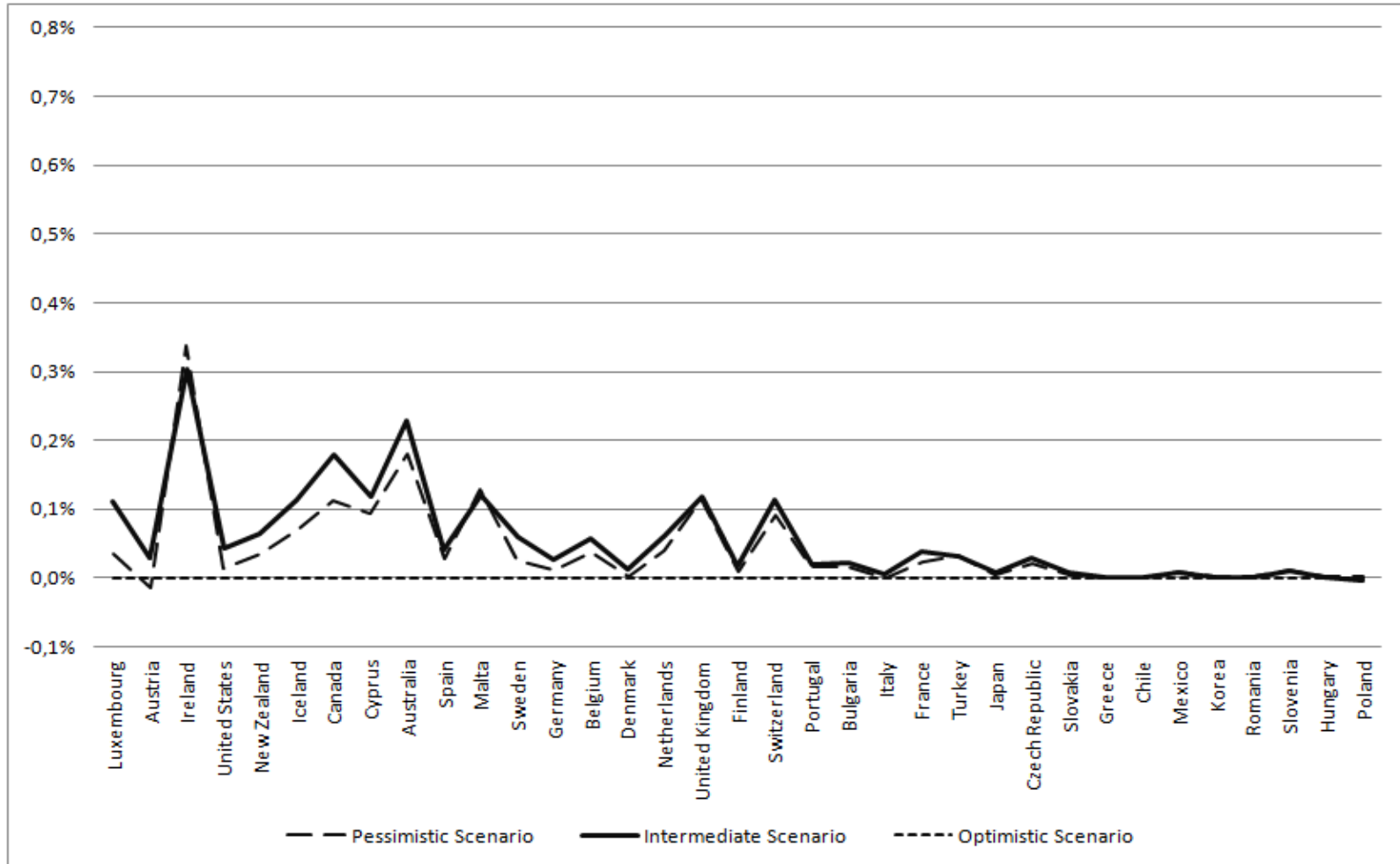

Note: Values on the vertical axis are the simulated aggregate employment effects (in percentage of the initial employment) of immigration on natives. We omit Israel and Lithuania, Latvia and Estonia from the chart as they are outliers see (Table A5). The parameter values corresponding to the Pessimistic, Intermediate and Optimistic Scenario are reported in Table 4. 
Figure 3: Wage effects of total emigration 1990-2000 on native workers

(Countries ranked left-to-right by emigration rate of college educated)

3.a. Percentage effects of total emigration on less educated native wages

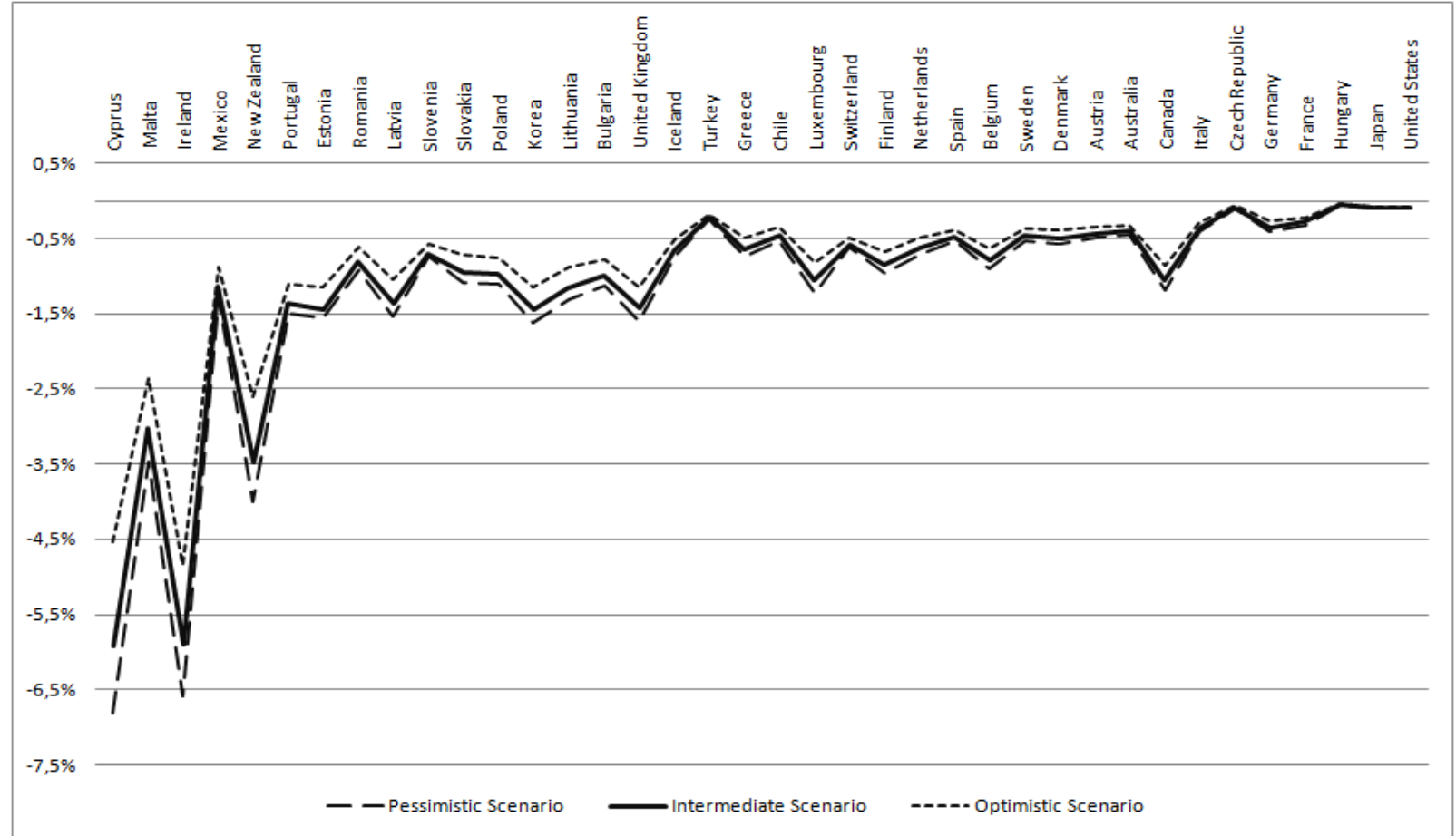

3.b. Percentage effects of total emigration on average native wages

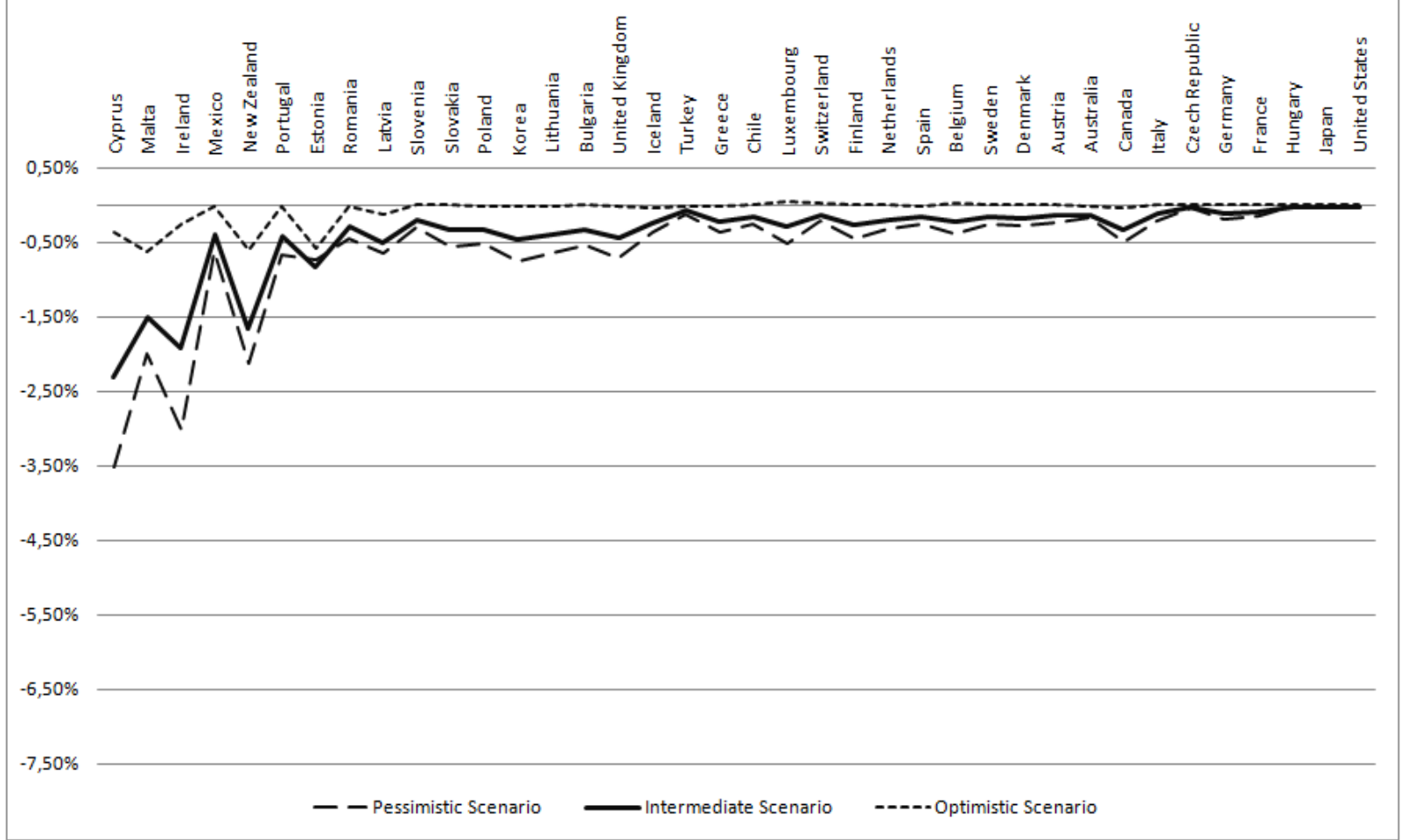

Note: Values on the vertical axis are the simulated wage effects (in percentage of the initial wage) of emigration on natives. We omit Israel from the chart. The parameter values corresponding to the "Pessimistic", "Intermediate" and "Optimistic" scenarios are reported in Table 4. 
Figure 4: Wage effects of total immigration 1990-2000, accounting for undocumented and downgrading (Countries ranked left-to-right by immigration rate)

4.a. Percentage effects of total emigration on less educated native wages

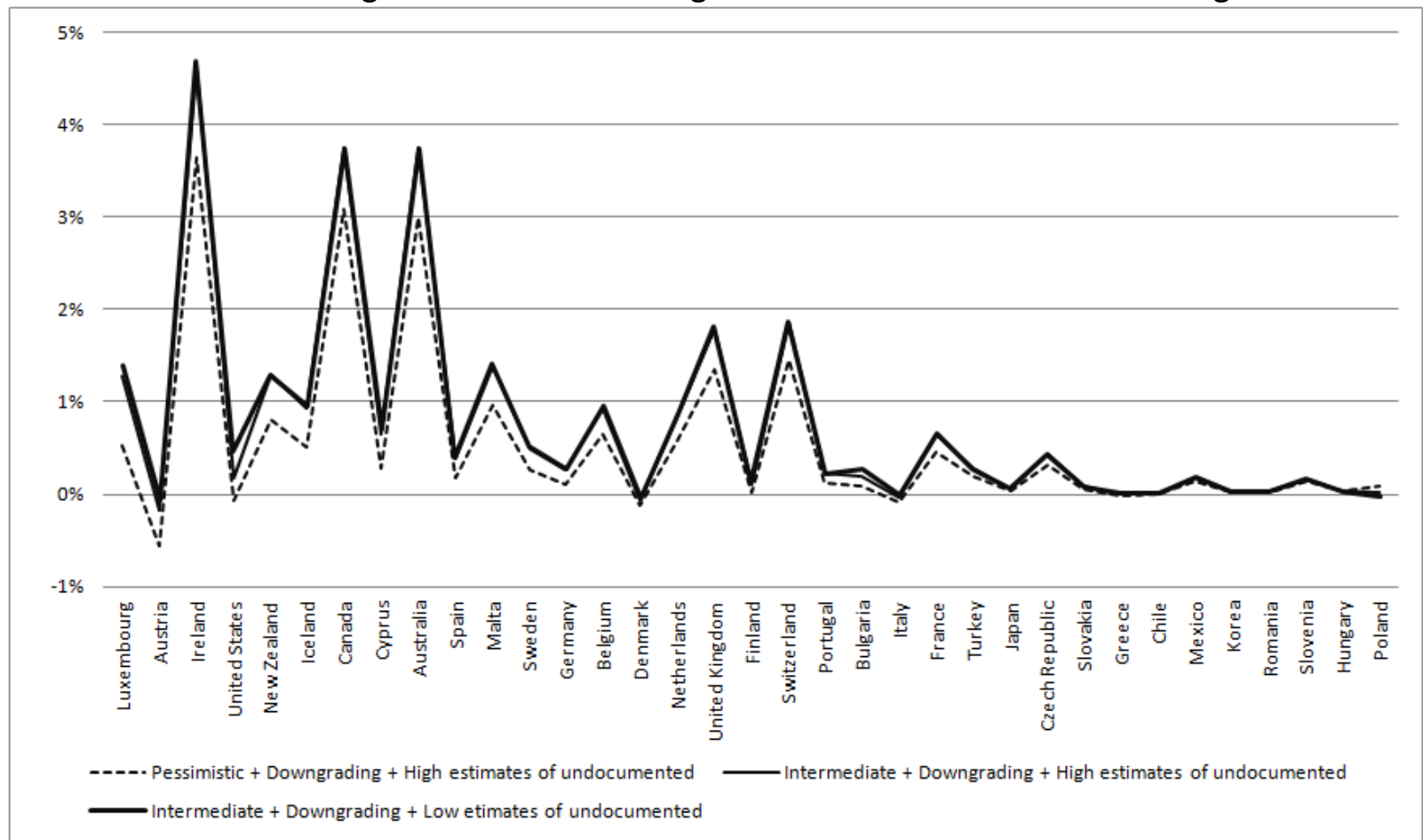

4.b. Percentage effects of total emigration on average native wages

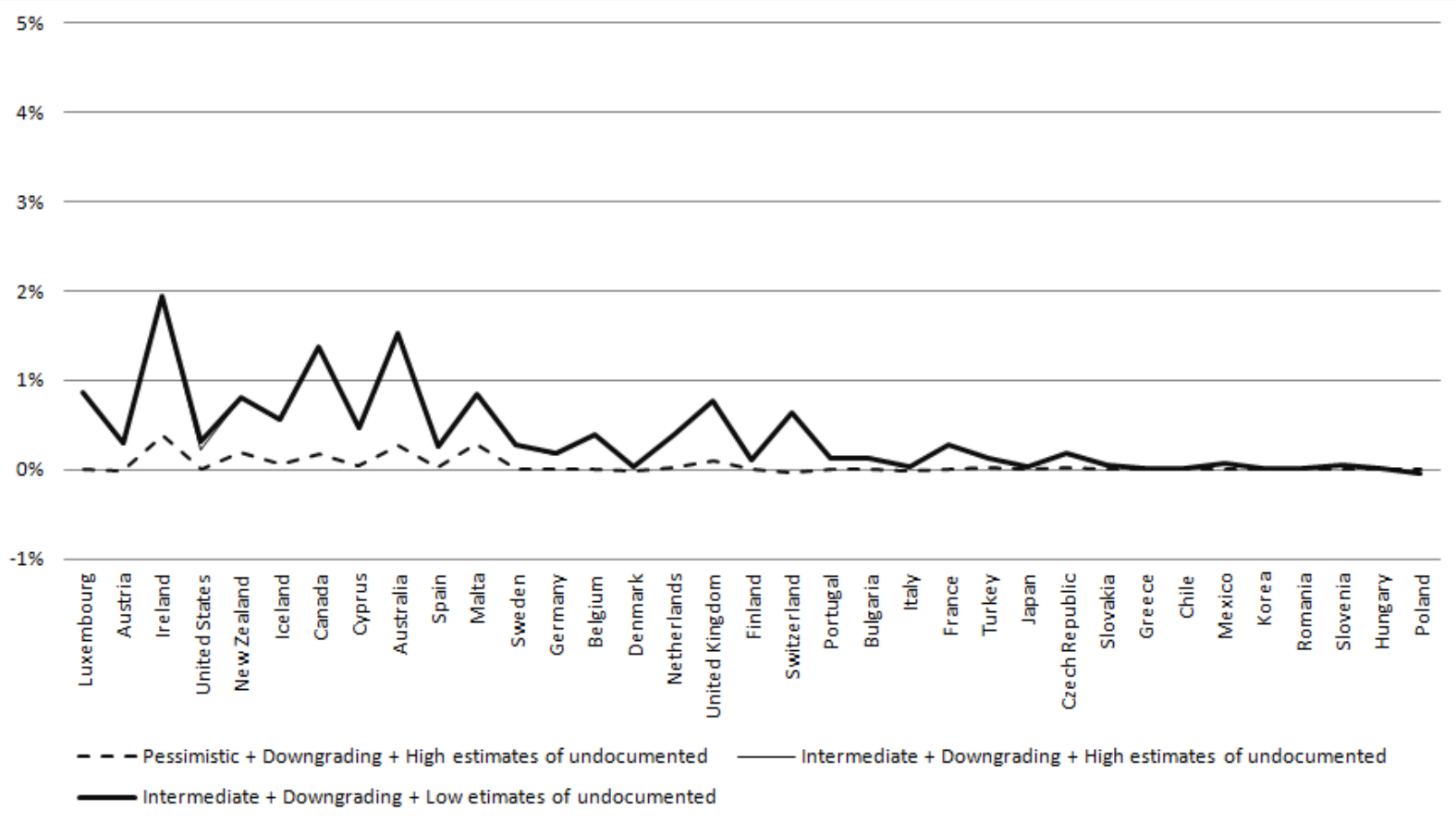

Note: Values on the vertical axis are the simulated wage effects (in percentage of the initial wage) of immigration on natives. We omit Israel and Lithuania, Latvia and Estonia from the chart as they are outliers. The parameter values corresponding to the "Pessimistic", "Intermediate" and "Optimistic" scenarios are reported in Table 4. The correction for undocumented is done using data from the European Union (2009) dataset. The correction for downgrading uses occupational distribution of immigrants by schooling in each country from the OECD DIOC-E database. 
Figure 5: Wage effects of non-OECD immigrants 1990-2000 on native workers

(Countries ranked left-to-right by immigration rate from non-OECD countries)

5.a. Percentage effects of non-OECD immigrants on less educated native wages

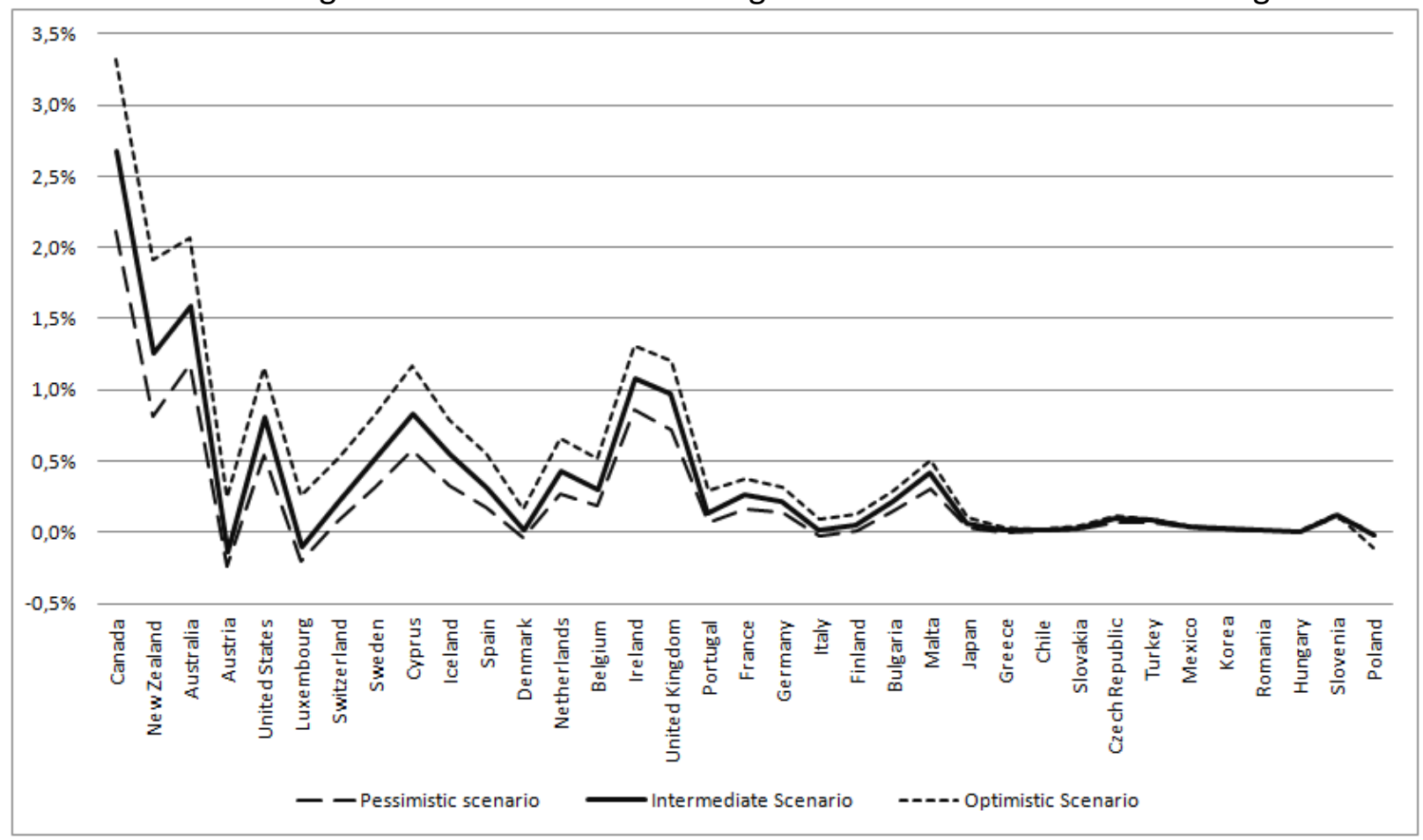

5.b. Percentage effects of non-OECD immigrants on average native wages

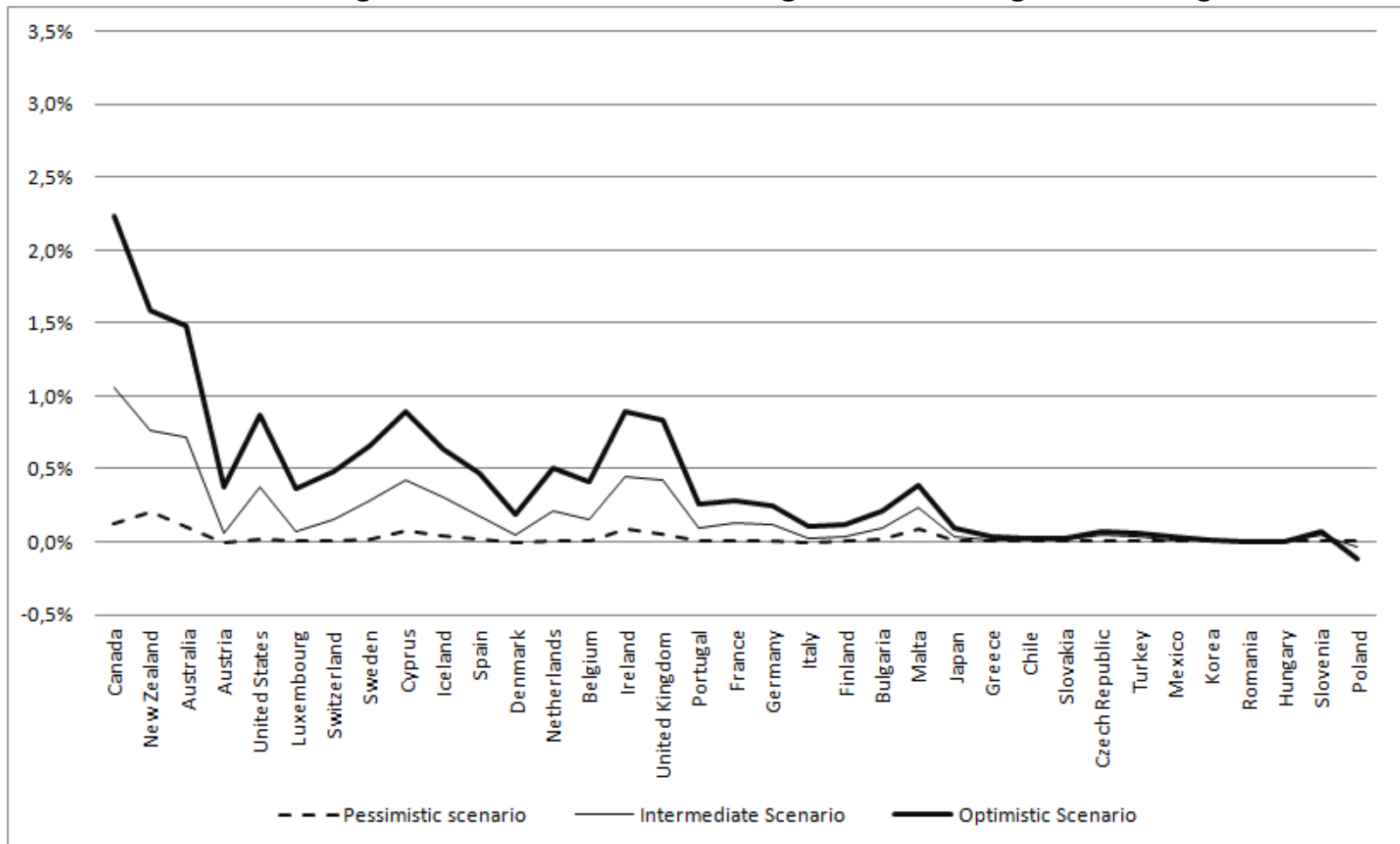

Note: Only the net inflow of immigrants, born in non-OECD countries is included in the analysis. The remaining definitions are as in Figure 1. 
Figure 6: Wage effects of non-OECD immigrants 1990-2000, accounting for undocumented and downgrading

(Countries ranked left-to-right by non-OECD immigration rate)

6.a. Percentage effects of non-OECD immigrants on less educated native wages

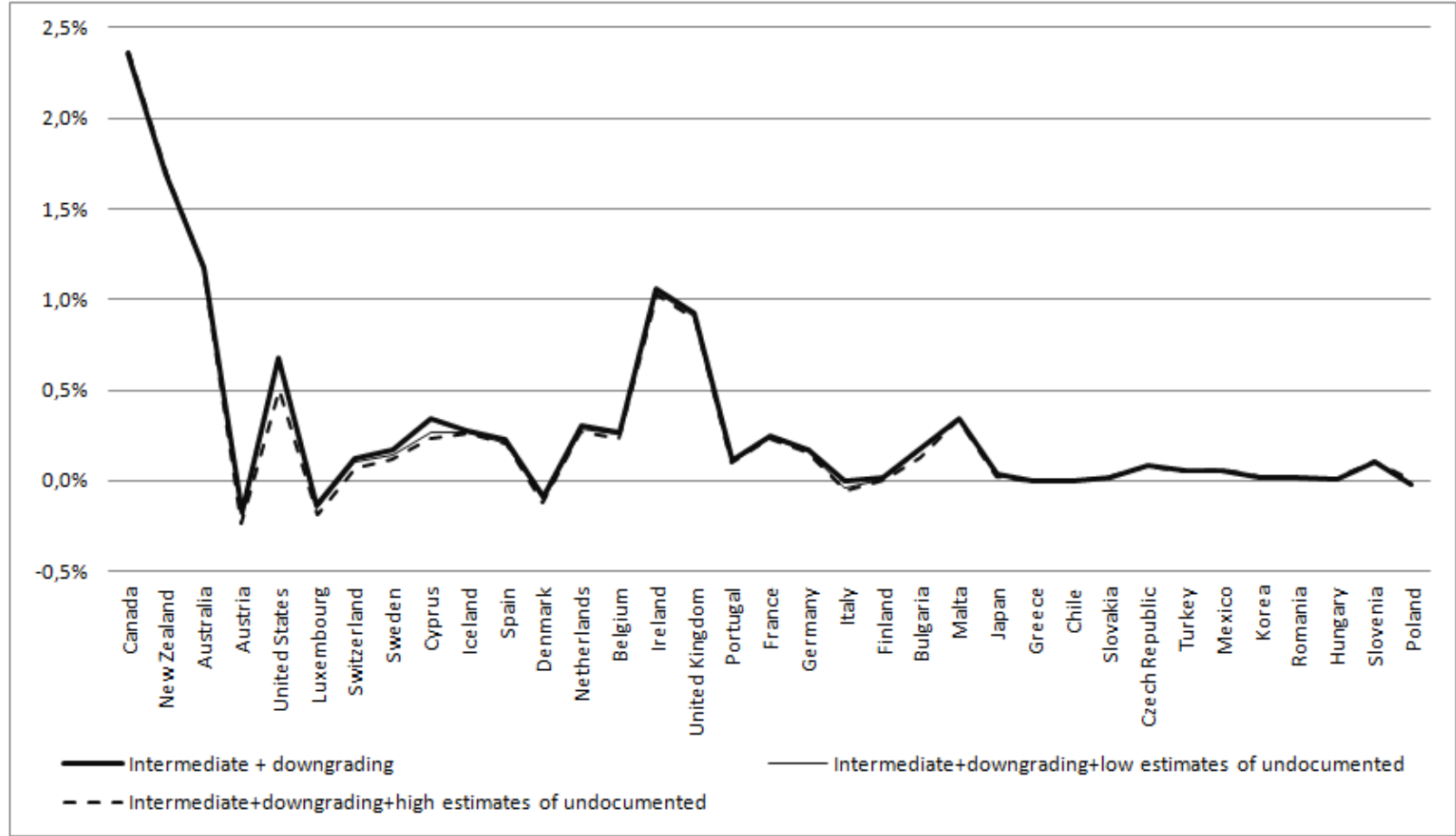

6.b. Percentage effects of non-OECD immigrants on average native wages

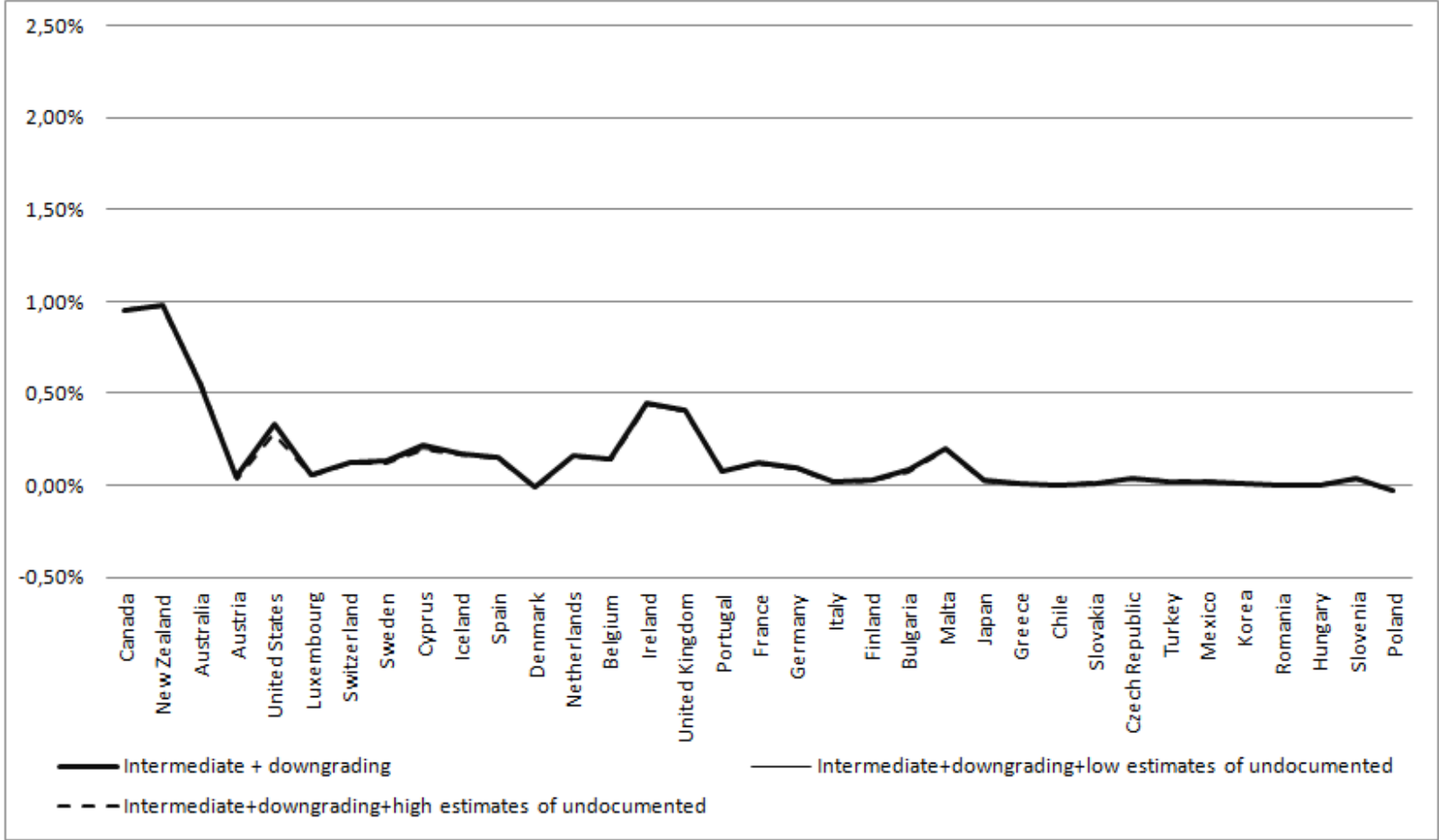

Note: Only non-OECD immigrants plus correction for undocumented and downgrading, as in Figure 4. 
Figure 7: Wage effects in 2000-2007 total immigration on native workers

(Countries ranked left-to-right by immigration rate - Sample for the US and EU countries)

7.a. Percentage effects of total emigration on less educated native wages

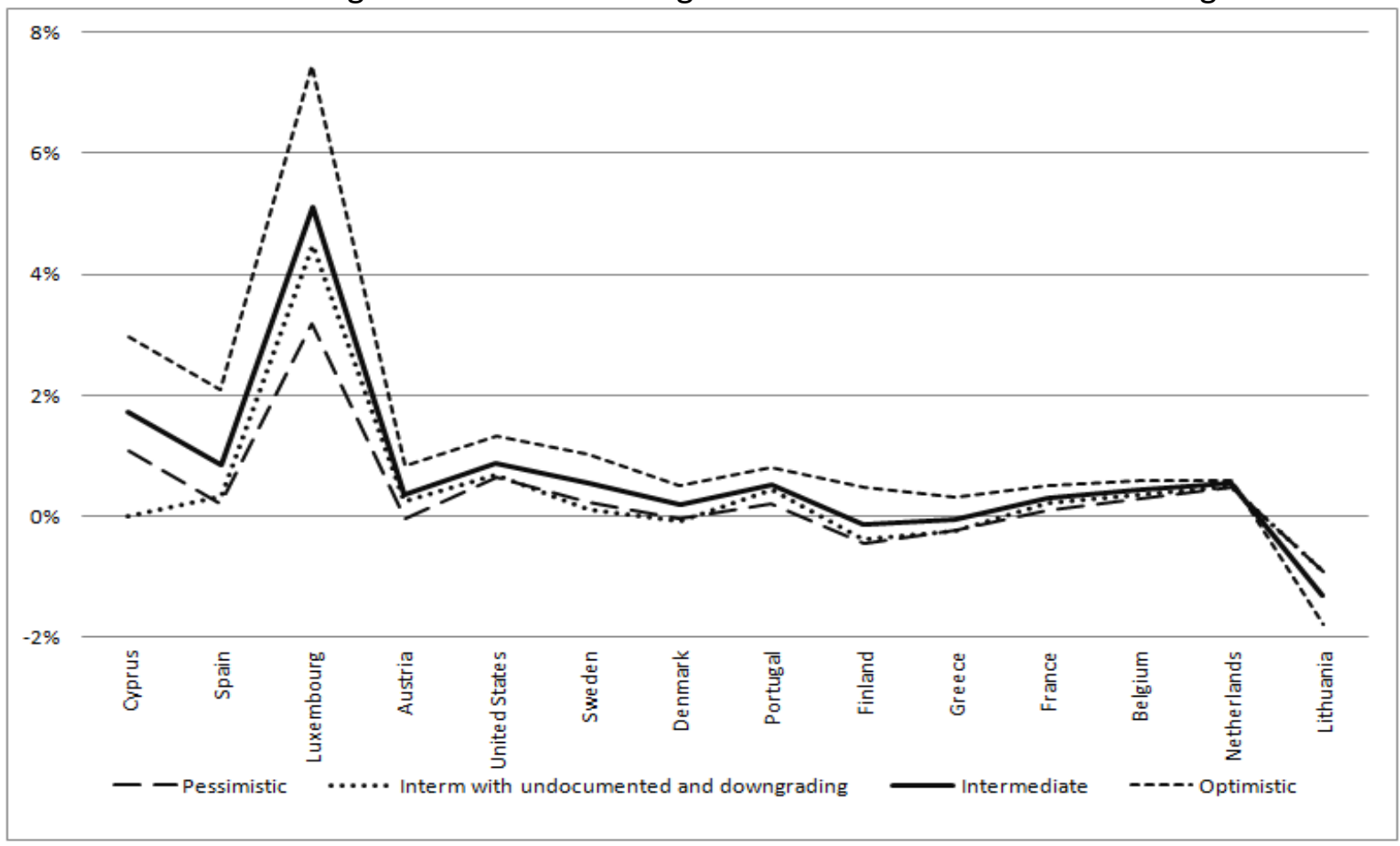

7.b. Percentage effects of total emigration on average native wages

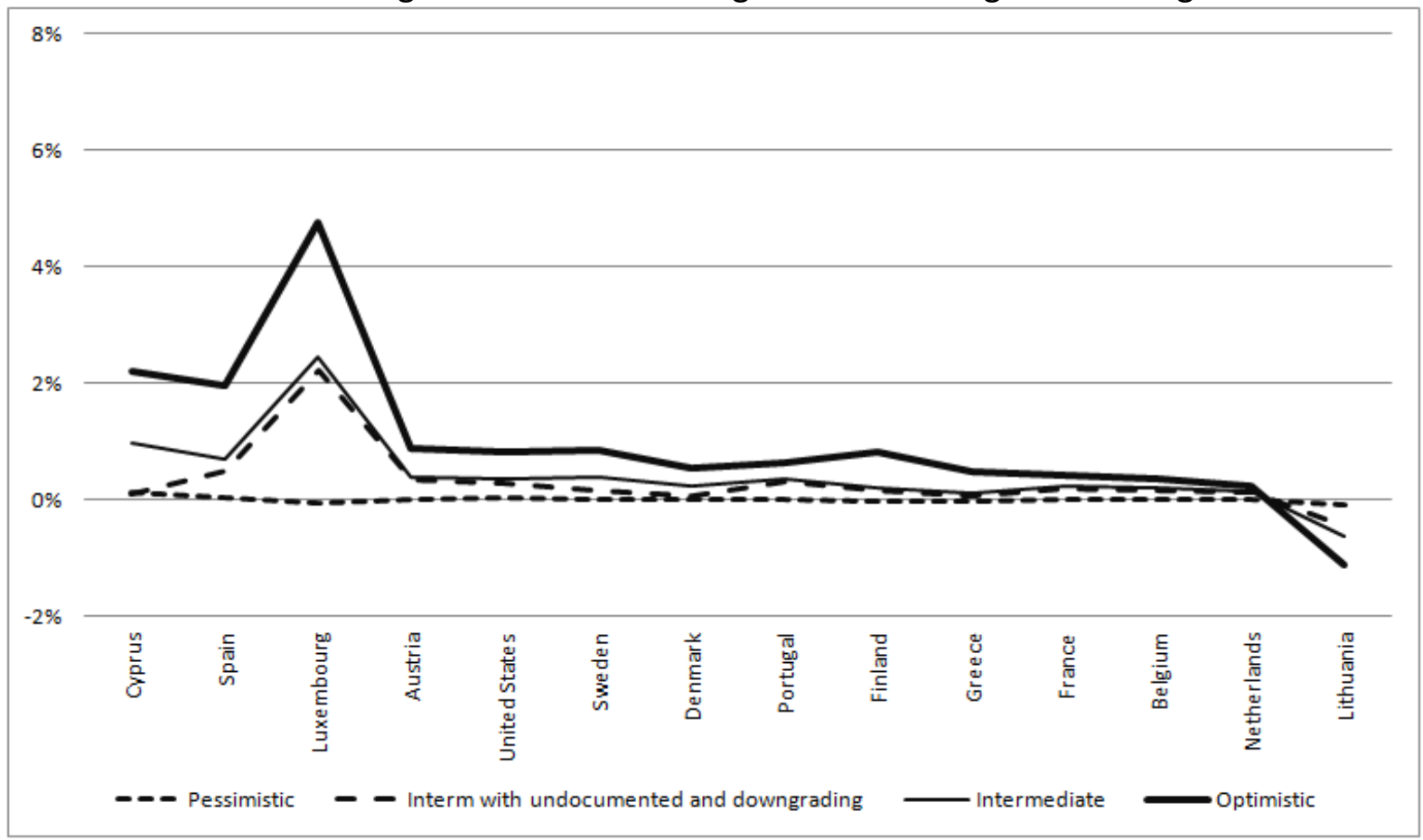

Note: The stock of immigrants and net immigration are calculated using EU Labor Force Survey data for European countries and American Community Survey data for the US. The years considered are 2000 and 2007 for the European countries and 2000-2009 for the US. We only include European countries with at least $80 \%$ of non-missing observations for age, schooling and country of birth. 
Figure A1: Short-run wage effects of 2000-2007 immigration, with undocumented and downgrading (Countries ranked left-to-right by immigration rate - Sample for the US and EU countries)

A1.a. Percentage effects of total emigration on less educated native wages

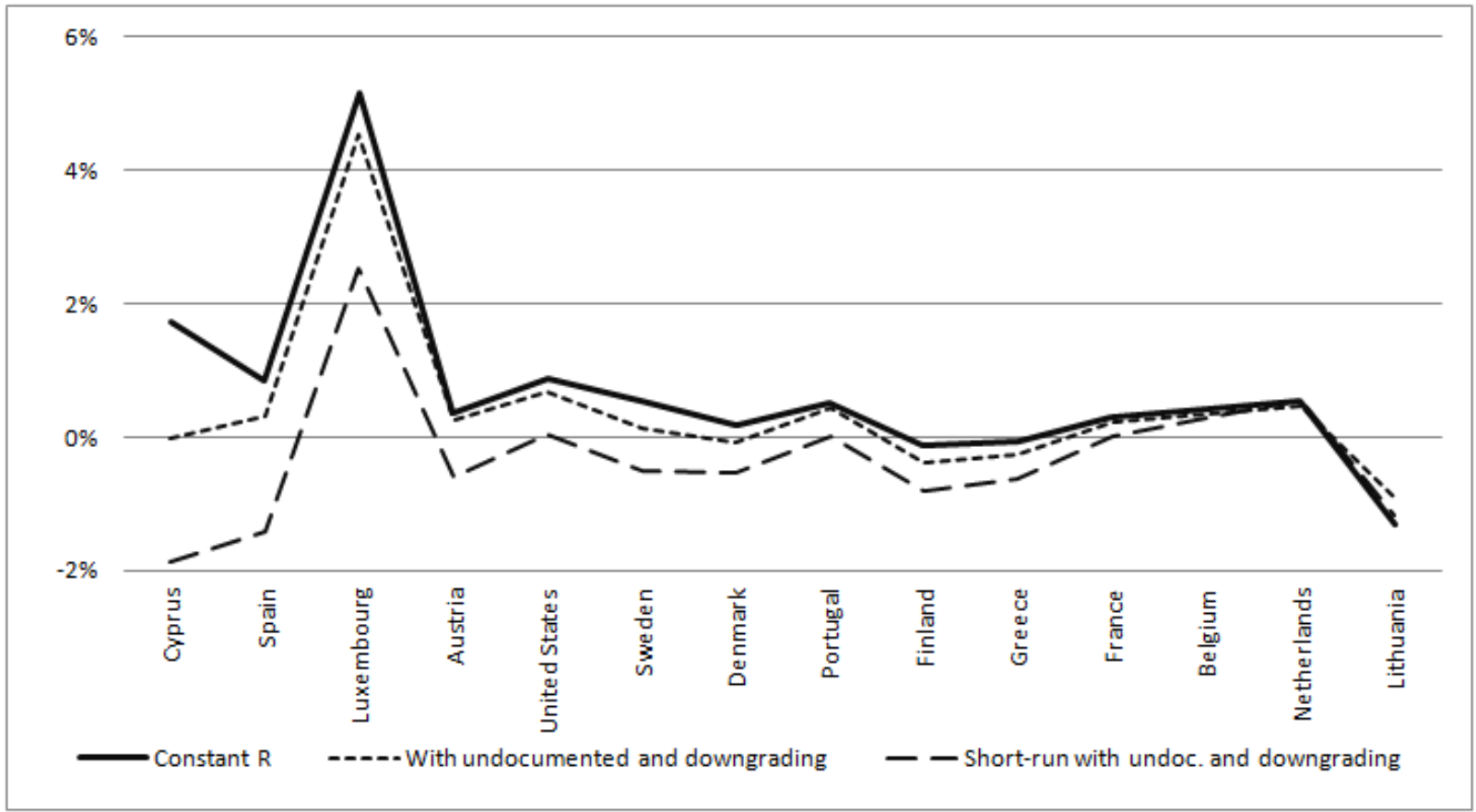

A1.b. Percentage effects of total emigration on average native wages

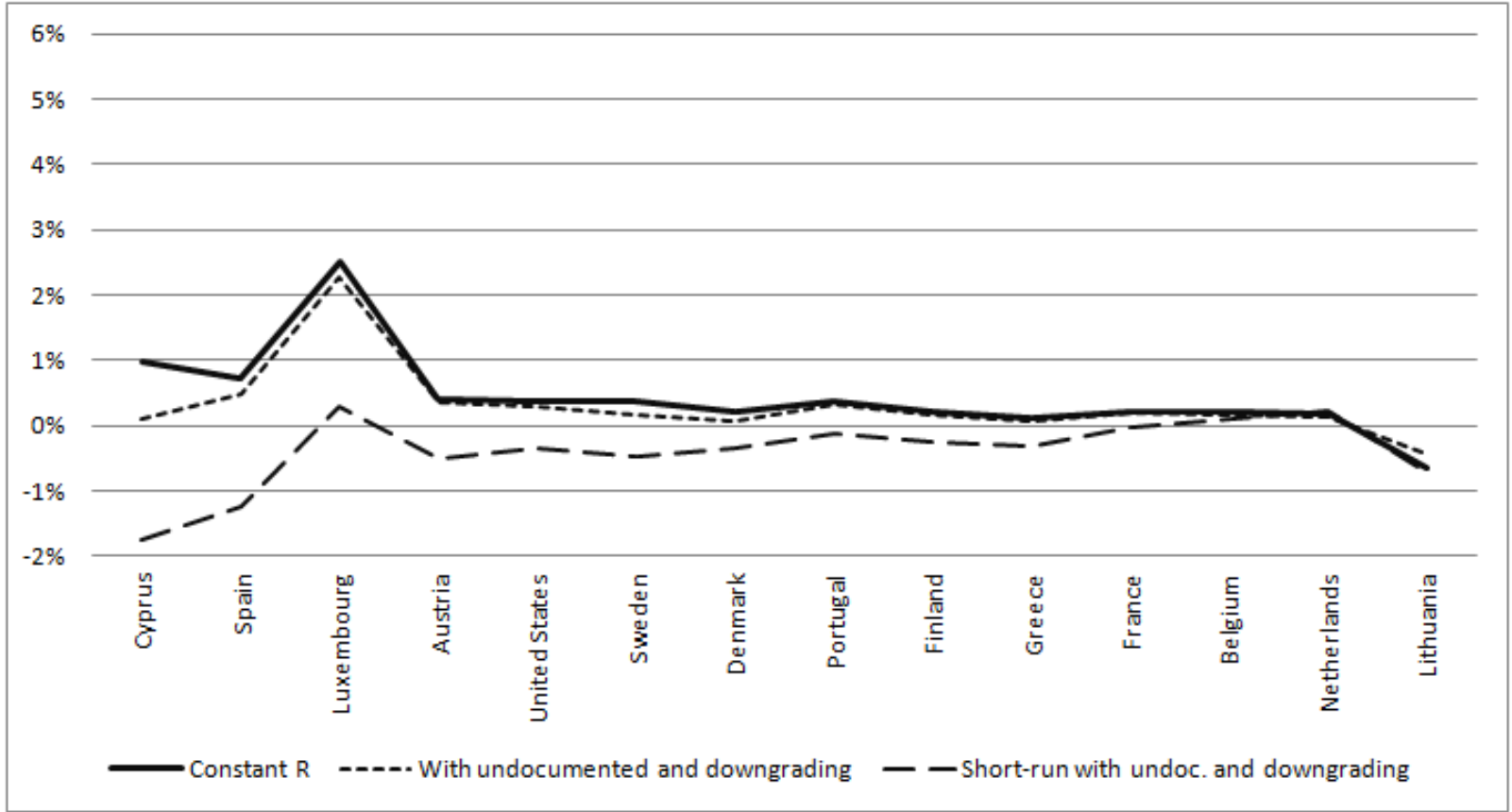

Note: The short-run (within 2 years) effects are calculated accounting for sluggish capital adjustment over the period 2000-2007. 
Table 1: Immigration rates $\mathbf{1 9 9 0 - 2 0 0 0 ~ ( r a n k e d ~ b y ~ t o t a l ~ i m m i g r a t i o n ~ r a t e ) ~}$

\begin{tabular}{|c|c|c|c|c|}
\hline Country & $\begin{array}{l}\text { Total Immigration } \\
\text { rates, from all } \\
\text { countries }\end{array}$ & $\begin{array}{l}\text { College Educated } \\
\text { Immigration rates: from } \\
\text { all countries }\end{array}$ & $\begin{array}{l}\text { Total Immigration } \\
\text { rates from non- } \\
\text { OECD countries }\end{array}$ & $\begin{array}{c}\text { College Educated } \\
\text { Immigration rates } \\
\text { from non-OECD } \\
\text { countries } \\
\end{array}$ \\
\hline Israel & $14.35 \%$ & $60.19 \%$ & $15.14 \%$ & $47.03 \%$ \\
\hline Luxembourg & $12.53 \%$ & $16.47 \%$ & $3.03 \%$ & $2.17 \%$ \\
\hline Austria & $9.35 \%$ & $7.87 \%$ & $3.42 \%$ & $2.11 \%$ \\
\hline Ireland & $7.60 \%$ & $28.02 \%$ & $1.65 \%$ & $6.12 \%$ \\
\hline United States & $5.71 \%$ & $6.50 \%$ & $3.40 \%$ & $4.71 \%$ \\
\hline New Zealand & $5.61 \%$ & $7.61 \%$ & $4.79 \%$ & $8.11 \%$ \\
\hline Iceland & $5.25 \%$ & $16.44 \%$ & $2.17 \%$ & $5.41 \%$ \\
\hline Canada & $5.21 \%$ & $10.81 \%$ & $5.59 \%$ & $9.06 \%$ \\
\hline Cyprus & $4.76 \%$ & $13.07 \%$ & $2.50 \%$ & $5.95 \%$ \\
\hline Australia & $3.79 \%$ & $13.70 \%$ & $3.66 \%$ & $6.82 \%$ \\
\hline Spain & $3.32 \%$ & $5.80 \%$ & $2.02 \%$ & $3.28 \%$ \\
\hline Malta & $2.84 \%$ & $18.73 \%$ & $0.59 \%$ & $4.41 \%$ \\
\hline Sweden & $2.66 \%$ & $6.63 \%$ & $2.59 \%$ & $4.29 \%$ \\
\hline Germany & $2.64 \%$ & $3.91 \%$ & $0.90 \%$ & $1.65 \%$ \\
\hline Belgium & $2.63 \%$ & $5.68 \%$ & $1.69 \%$ & $2.40 \%$ \\
\hline Denmark & $2.54 \%$ & $2.95 \%$ & $1.82 \%$ & $1.57 \%$ \\
\hline Netherlands & $2.39 \%$ & $6.60 \%$ & $1.77 \%$ & $3.16 \%$ \\
\hline United Kingdom & $2.13 \%$ & $11.26 \%$ & $1.64 \%$ & $6.13 \%$ \\
\hline Finland & $1.74 \%$ & $2.34 \%$ & $0.65 \%$ & $0.70 \%$ \\
\hline Switzerland & $1.61 \%$ & $9.29 \%$ & $2.63 \%$ & $2.96 \%$ \\
\hline Portugal & $1.55 \%$ & $2.99 \%$ & $1.23 \%$ & $1.76 \%$ \\
\hline Bulgaria & $1.06 \%$ & $2.52 \%$ & $0.62 \%$ & $1.56 \%$ \\
\hline Italy & $1.00 \%$ & $1.08 \%$ & $0.73 \%$ & $0.57 \%$ \\
\hline France & $0.81 \%$ & $3.38 \%$ & $1.01 \%$ & $1.89 \%$ \\
\hline Turkey & $0.71 \%$ & $7.10 \%$ & $0.06 \%$ & $1.27 \%$ \\
\hline Japan & $0.46 \%$ & $0.78 \%$ & $0.39 \%$ & $0.54 \%$ \\
\hline Czech Republic & $0.39 \%$ & $5.35 \%$ & $0.07 \%$ & $1.02 \%$ \\
\hline Slovakia & $0.35 \%$ & $1.24 \%$ & $0.08 \%$ & $0.29 \%$ \\
\hline Greece & $0.24 \%$ & $0.34 \%$ & $0.19 \%$ & $0.21 \%$ \\
\hline Chile & $0.13 \%$ & $0.26 \%$ & $0.12 \%$ & $0.15 \%$ \\
\hline Mexico & $0.11 \%$ & $1.09 \%$ & $0.03 \%$ & $0.36 \%$ \\
\hline Korea & $0.00 \%$ & $0.15 \%$ & $0.00 \%$ & $0.11 \%$ \\
\hline Romania & $-0.04 \%$ & $0.27 \%$ & $-0.02 \%$ & $0.13 \%$ \\
\hline Slovenia & $-0.09 \%$ & $1.31 \%$ & $-0.08 \%$ & $0.84 \%$ \\
\hline Hungary & $-0.12 \%$ & $0.17 \%$ & $-0.03 \%$ & $0.04 \%$ \\
\hline Poland & $-1.14 \%$ & $-0.87 \%$ & $-0.77 \%$ & $-0.63 \%$ \\
\hline Lithuania & $-2.96 \%$ & $0.36 \%$ & $-2.71 \%$ & $0.34 \%$ \\
\hline Latvia & $-15.58 \%$ & $-17.93 \%$ & $-16.88 \%$ & $-19.79 \%$ \\
\hline Estonia & $-16.73 \%$ & $-25.46 \%$ & $-16.60 \%$ & $-25.80 \%$ \\
\hline
\end{tabular}


Table 2: Emigration rates 1990-2000, total and for college graduates (Ranked by college-emigration rates)

\begin{tabular}{|c|c|c|}
\hline Country & Total & College graduates \\
\hline Cyprus & $1.78 \%$ & $29.31 \%$ \\
\hline Malta & $-1.77 \%$ & $27.99 \%$ \\
\hline Ireland & $-4.23 \%$ & $23.30 \%$ \\
\hline Mexico & $11.58 \%$ & $19.76 \%$ \\
\hline New Zealand & $6.82 \%$ & $16.85 \%$ \\
\hline Portugal & $3.09 \%$ & $12.57 \%$ \\
\hline Estonia & $4.89 \%$ & $9.89 \%$ \\
\hline Romania & $1.23 \%$ & $9.89 \%$ \\
\hline Latvia & $2.42 \%$ & $9.17 \%$ \\
\hline Slovenia & $4.90 \%$ & $9.15 \%$ \\
\hline Slovakia & $1.04 \%$ & $8.74 \%$ \\
\hline Poland & $0.49 \%$ & $8.32 \%$ \\
\hline Korea & $1.76 \%$ & $8.20 \%$ \\
\hline Lithuania & $0.76 \%$ & $7.51 \%$ \\
\hline Bulgaria & $2.50 \%$ & $7.19 \%$ \\
\hline United Kingdom & $0.40 \%$ & $6.36 \%$ \\
\hline Iceland & $2.68 \%$ & $5.99 \%$ \\
\hline Turkey & $2.43 \%$ & $5.57 \%$ \\
\hline Greece & $0.25 \%$ & $4.57 \%$ \\
\hline Chile & $1.24 \%$ & $4.05 \%$ \\
\hline Luxembourg & $0.73 \%$ & $3.92 \%$ \\
\hline Switzerland & $2.13 \%$ & $3.64 \%$ \\
\hline Finland & $0.02 \%$ & $2.95 \%$ \\
\hline Netherlands & $0.61 \%$ & $2.94 \%$ \\
\hline Spain & $0.06 \%$ & $2.92 \%$ \\
\hline Belgium & $0.51 \%$ & $2.91 \%$ \\
\hline Sweden & $0.82 \%$ & $2.30 \%$ \\
\hline Denmark & $0.30 \%$ & $2.22 \%$ \\
\hline Austria & $0.32 \%$ & $2.03 \%$ \\
\hline Australia & $1.07 \%$ & $1.70 \%$ \\
\hline Canada & $0.17 \%$ & $1.65 \%$ \\
\hline Italy & $-0.29 \%$ & $1.63 \%$ \\
\hline Czech Republic & $0.74 \%$ & $1.48 \%$ \\
\hline Germany & $0.20 \%$ & $1.37 \%$ \\
\hline France & $0.44 \%$ & $1.31 \%$ \\
\hline Hungary & $0.04 \%$ & $0.37 \%$ \\
\hline Japan & $0.06 \%$ & $0.36 \%$ \\
\hline United States & $0.10 \%$ & $0.23 \%$ \\
\hline
\end{tabular}


Table 3: Parameter values in the difference scenarios

\begin{tabular}{lccc}
\hline Parameters: & $\begin{array}{c}\text { Pessimistic } \\
\text { Scenario }\end{array}$ & $\begin{array}{c}\text { Intermediate } \\
\text { scenario }\end{array}$ & $\begin{array}{c}\text { Optimistic } \\
\text { scenario }\end{array}$ \\
\hline$\sigma_{\mathrm{q}}$ : Elasticity of Substitution between more and less educated & 1.3 & 1.75 & 2.00 \\
$\sigma_{\mathrm{m}}:$ Elasticity of substitution between immigrants and natives & infinite & 20 & 6 \\
$\lambda:$ Intensity of college externalities & 0 & 0.45 & 0.75 \\
$\gamma:$ Elasticity of labor supply & 0.2 & 0.1 & 0 \\
\hline
\end{tabular}

Table 4: Foreign-born in aggregate OECD countries

\begin{tabular}{lccc}
\hline OECD as receiving countries & All & $\begin{array}{c}\text { Less than college } \\
\text { educated }\end{array}$ & $\begin{array}{c}\text { college } \\
\text { educated }\end{array}$ \\
\hline (Foreign-born/Total) in 2000 & $7.73 \%$ & $6.95 \%$ & $9.74 \%$ \\
(non OECD- born)/Total in 2000 & $3.78 \%$ & $3.17 \%$ & $5.38 \%$ \\
(net inflow 1990-2000)/ Total 2000 & $2.41 \%$ & $1.53 \%$ & $5.46 \%$ \\
(net inflow 1990-2000 from non-OECD)/ Total 2000 & $1.52 \%$ & $0.93 \%$ & $3.54 \%$ \\
\hline
\end{tabular}

Table 5: Immigration rates $1990-2000$ and $2000-2007$ for a sample of EU countries and the US

\begin{tabular}{ccc}
\hline Country & $1990-2000$ & $2000-2007$ \\
\hline Cyprus & $4.76 \%$ & $11.31 \%$ \\
Spain & $3.32 \%$ & $11.26 \%$ \\
Luxembourg & $12.53 \%$ & $8.46 \%$ \\
Austria & $9.35 \%$ & $5.06 \%$ \\
United States & $5.71 \%$ & $3.76 \%$ \\
Sweden & $2.66 \%$ & $3.66 \%$ \\
Denmark & $2.54 \%$ & $2.86 \%$ \\
Portugal & $1.55 \%$ & $2.81 \%$ \\
Finland & $1.74 \%$ & $2.68 \%$ \\
Greece & $0.24 \%$ & $2.46 \%$ \\
France & $0.81 \%$ & $1.26 \%$ \\
Belgium & $2.63 \%$ & $0.39 \%$ \\
Netherlands & $2.39 \%$ & $-0.45 \%$ \\
Lithuania & $-2.96 \%$ & $-1.71 \%$ \\
\hline
\end{tabular}

Note: the 2000-07 figures are obtained as our elaborations from the EULFS data for the European countries, and using the ACS data for the US. The US rates are relative to the $2000-2009$ period. The $1990-2000$ figures are taken from Table 1. 


\section{Appendix}

Table A1: Immigration stocks aged 25+ in 1990 and 2000 (in millions)

\begin{tabular}{l|ccc|ccc}
\hline \hline & \multicolumn{3}{|c|}{1990} & \multicolumn{2}{c}{2000} \\
& $\begin{array}{c}\text { Less } \\
\text { educated }\end{array}$ & $\begin{array}{c}\text { College } \\
\text { graduates }\end{array}$ & Total & $\begin{array}{c}\text { Less } \\
\text { educated }\end{array}$ & $\begin{array}{c}\text { College } \\
\text { graduates }\end{array}$ \\
\hline $\begin{array}{l}\text { OECD destinations (30/30) } \\
\text { Observed non-OECD destinations }\end{array}$ & 12.5 & 12.3 & 40.8 & 37.1 & 20.3 & 57.4 \\
$\begin{array}{l}\text { (31/46) } \\
\text { Imputed non OECD destinations } \\
(134 / 119)\end{array}$ & 22.9 & 1.5 & 14.0 & 17.1 & 3.1 & 20.2 \\
Total (195/195) & 63.9 & 2.5 & 25.4 & 20.1 & 2.8 & 22.9 \\
\hline \hline
\end{tabular}

Note: The data are from the Docquier et al (2010) database. It expands the OECD data of Docquier and Marfouk (2006) to 31 and 46 non-OECD countries (for 1990 and 2000 respectively) and imputed data on migrant stocks for the remaining of 195 countries covering the whole world. 
Table A2: Stock of emigrants in 1990 and 2000 (x 1,000): Observed and imputed values

\begin{tabular}{|c|c|c|c|c|c|c|c|c|}
\hline & \multicolumn{4}{|c|}{1990} & \multicolumn{4}{|c|}{2000} \\
\hline & Total & Observed & Imputed & Imputed/tot & Total & Observed & Imputed & Imputed/tot \\
\hline Australia & 163.9 & 147.1 & 16.7 & 0.102 & 242.7 & 227.4 & 15.3 & 0.063 \\
\hline Austria & 414.7 & 395.3 & 19.4 & 0.047 & 430.2 & 386.2 & 43.9 & 0.102 \\
\hline Belgium & 337.4 & 293.8 & 43.7 & 0.129 & 368.2 & 328.0 & 40.1 & 0.109 \\
\hline Bulgaria & 422.2 & 393.7 & 28.6 & 0.068 & 564.3 & 540.0 & 24.3 & 0.043 \\
\hline Canada & 856.7 & 846.6 & 10.1 & 0.012 & 880.9 & 874.7 & 6.3 & 0.007 \\
\hline Cyprus & 109.7 & 109.4 & 0.3 & 0.003 & 116.5 & 116.5 & 0.0 & 0.000 \\
\hline Chile & 169.0 & 163.7 & 5.3 & 0.032 & 252.3 & 247.9 & 4.5 & 0.018 \\
\hline Czech Republic & 171.6 & 169.3 & 2.3 & 0.014 & 217.2 & 215.4 & 1.8 & 0.008 \\
\hline Denmark & 160.6 & 160.1 & 0.5 & 0.003 & 170.8 & 169.0 & 1.8 & 0.010 \\
\hline Estonia & 61.7 & 37.3 & 24.4 & 0.396 & 91.6 & 61.7 & 29.9 & 0.327 \\
\hline Finland & 270.2 & 270.2 & 0.0 & 0.000 & 270.8 & 270.8 & 0.0 & 0.000 \\
\hline France & $1,001.7$ & 697.4 & 304.2 & 0.304 & $1,148.6$ & 917.4 & 231.2 & 0.201 \\
\hline Germany & $2,448.6$ & $2,359.0$ & 89.6 & 0.037 & $2,554.5$ & $2,451.8$ & 102.7 & 0.040 \\
\hline Greece & 861.1 & 756.8 & 104.3 & 0.121 & 876.4 & 757.1 & 119.2 & 0.136 \\
\hline Hungary & 339.1 & 332.3 & 6.8 & 0.020 & 342.0 & 325.6 & 16.4 & 0.048 \\
\hline Iceland & 14.7 & 14.7 & 0.0 & 0.000 & 18.4 & 18.4 & 0.0 & 0.000 \\
\hline Ireland & 766.5 & 745.6 & 20.9 & 0.027 & 689.1 & 686.6 & 2.5 & 0.004 \\
\hline Israel & 298.7 & 114.2 & 184.5 & 0.618 & 419.2 & 157.8 & 261.4 & 0.624 \\
\hline Italy & $2,714.3$ & $2,660.0$ & 54.3 & 0.020 & $2,604.9$ & $2,548.6$ & 56.3 & 0.022 \\
\hline Japan & 458.0 & 444.3 & 13.8 & 0.030 & 509.4 & 488.9 & 20.5 & 0.040 \\
\hline Korea & 859.7 & 838.5 & 21.2 & 0.025 & $1,264.0$ & $1,225.5$ & 38.6 & 0.031 \\
\hline Latvia & 90.4 & 55.7 & 34.6 & 0.383 & 116.6 & 77.5 & 39.1 & 0.335 \\
\hline Lithuania & 251.8 & 183.6 & 68.2 & 0.271 & 267.3 & 205.9 & 61.4 & 0.230 \\
\hline Luxembourg & 23.8 & 23.8 & 0.0 & 0.000 & 25.2 & 25.2 & 0.0 & 0.000 \\
\hline Malta & 99.6 & 99.6 & 0.0 & 0.000 & 95.8 & 95.5 & 0.3 & 0.003 \\
\hline Mexico & $2,725.2$ & $2,693.8$ & 31.4 & 0.012 & $6,502.1$ & $6,457.5$ & 44.6 & 0.007 \\
\hline Netherlands & 589.1 & 574.7 & 14.3 & 0.024 & 639.7 & 625.5 & 14.2 & 0.022 \\
\hline New Zealand & 258.2 & 246.4 & 11.9 & 0.046 & 370.3 & 358.5 & 11.8 & 0.032 \\
\hline Poland & $1,309.8$ & $1,194.4$ & 115.4 & 0.088 & $1,419.2$ & $1,269.2$ & 150.0 & 0.106 \\
\hline Portugal & $1,256.4$ & $1,160.8$ & 95.6 & 0.076 & $1,450.4$ & $1,315.4$ & 135.0 & 0.093 \\
\hline Romania & 464.6 & 462.0 & 2.6 & 0.006 & 633.8 & 621.2 & 12.6 & 0.020 \\
\hline Slovakia & 350.8 & 342.3 & 8.5 & 0.024 & 383.3 & 378.5 & 4.8 & 0.013 \\
\hline Slovenia & 74.4 & 74.4 & 0.0 & 0.000 & 127.6 & 127.6 & 0.0 & 0.000 \\
\hline Spain & 959.4 & 897.6 & 61.9 & 0.064 & 973.3 & 924.7 & 48.6 & 0.050 \\
\hline Sweden & 138.9 & 135.5 & 3.4 & 0.025 & 182.2 & 174.7 & 7.4 & 0.041 \\
\hline Switzerland & 180.1 & 172.0 & 8.1 & 0.045 & 256.5 & 236.4 & 20.1 & 0.078 \\
\hline Turkey & $1,517.9$ & $1,488.0$ & 29.9 & 0.020 & $2,117.5$ & $2,082.2$ & 35.3 & 0.017 \\
\hline United Kingdom & $3,302.9$ & $3,070.0$ & 232.9 & 0.071 & $3,442.6$ & $3,260.4$ & 182.2 & 0.053 \\
\hline United States & 757.2 & 676.4 & 80.8 & 0.107 & 900.6 & 838.3 & 62.3 & 0.069 \\
\hline
\end{tabular}

Note: The observed emigrants are in one of the 30 OECD countries or one of the 46 (in 2000) or 31 (in1990) non-OECD countries for which we have data. The procedure to impute data is described in detail in the Data Appendix of the paper. 
Table A3: Wage income share of each group, $\operatorname{sh}(i, j)$

\begin{tabular}{|c|c|c|c|c|}
\hline Country & $\operatorname{sh}(h, n)$ & $\operatorname{sh}(h, f)$ & $\operatorname{sh}(I, n)$ & $\operatorname{sh}(I, f)$ \\
\hline Australia & 0.232 & 0.143 & 0.437 & 0.188 \\
\hline Austria & 0.237 & 0.007 & 0.706 & 0.051 \\
\hline Belgium & 0.278 & 0.018 & 0.614 & 0.089 \\
\hline Bulgaria & 0.211 & 0.001 & 0.786 & 0.002 \\
\hline Canada & 0.362 & 0.132 & 0.403 & 0.104 \\
\hline Chile & 0.165 & 0.000 & 0.833 & 0.002 \\
\hline Cyprus & 0.179 & 0.029 & 0.756 & 0.036 \\
\hline Czech Republic & 0.106 & 0.003 & 0.838 & 0.053 \\
\hline Denmark & 0.233 & 0.005 & 0.738 & 0.024 \\
\hline Estonia & 0.061 & 0.148 & 0.523 & 0.268 \\
\hline Finland & 0.276 & 0.002 & 0.716 & 0.006 \\
\hline France & 0.276 & 0.010 & 0.650 & 0.064 \\
\hline Germany & 0.258 & 0.010 & 0.696 & 0.037 \\
\hline Greece & 0.140 & 0.014 & 0.793 & 0.053 \\
\hline Hungary & 0.150 & 0.001 & 0.842 & 0.007 \\
\hline Iceland & 0.155 & 0.020 & 0.776 & 0.049 \\
\hline Ireland & 0.202 & 0.028 & 0.722 & 0.048 \\
\hline Israel & 0.243 & 0.090 & 0.275 & 0.392 \\
\hline Italy & 0.185 & 0.003 & 0.800 & 0.012 \\
\hline Japan & 0.283 & 0.002 & 0.710 & 0.005 \\
\hline Korea & 0.224 & 0.002 & 0.771 & 0.003 \\
\hline Latvia & 0.096 & 0.082 & 0.516 & 0.306 \\
\hline Lithuania & 0.145 & 0.024 & 0.737 & 0.095 \\
\hline Luxembourg & 0.226 & 0.058 & 0.518 & 0.198 \\
\hline Malta & 0.076 & 0.035 & 0.856 & 0.033 \\
\hline Mexico & 0.143 & 0.002 & 0.852 & 0.003 \\
\hline Netherlands & 0.207 & 0.035 & 0.633 & 0.125 \\
\hline New Zealand & 0.165 & 0.116 & 0.604 & 0.115 \\
\hline Poland & 0.126 & 0.007 & 0.832 & 0.035 \\
\hline Portugal & 0.156 & 0.003 & 0.835 & 0.006 \\
\hline Romania & 0.097 & 0.003 & 0.897 & 0.004 \\
\hline Slovakia & 0.126 & 0.000 & 0.872 & 0.001 \\
\hline Slovenia & 0.141 & 0.020 & 0.737 & 0.102 \\
\hline Spain & 0.169 & 0.008 & 0.800 & 0.024 \\
\hline Sweden & 0.246 & 0.018 & 0.669 & 0.068 \\
\hline Switzerland & 0.232 & 0.051 & 0.538 & 0.179 \\
\hline Turkey & 0.075 & 0.004 & 0.903 & 0.018 \\
\hline \multicolumn{5}{|l|}{ United } \\
\hline Kingdom & 0.221 & 0.019 & 0.715 & 0.045 \\
\hline United States & 0.443 & 0.039 & 0.480 & 0.038 \\
\hline
\end{tabular}

Note: The share of wage income to each group are calculated using employment from Docquier et al. (2010), data on return to schooling from Hendricks (2004) and data on native-immigrant premium from Kerr and Kerr (2009). 
Table A4: Simulated effects of immigrants on wages of less educated and average wages of natives

Effect on Average Wages of natives

Effect on Wages of Less Educated Natives

\begin{tabular}{|c|c|c|c|c|c|c|}
\hline Country & $\begin{array}{l}\text { Pessimistic } \\
\text { Scenario }\end{array}$ & $\begin{array}{l}\text { Intermediate } \\
\text { Scenario }\end{array}$ & $\begin{array}{l}\text { Optimistic } \\
\text { Scenario }\end{array}$ & $\begin{array}{l}\text { Pessimistic } \\
\text { Scenario }\end{array}$ & $\begin{array}{l}\text { Intermediate } \\
\text { Scenario }\end{array}$ & $\begin{array}{l}\text { Optimistic } \\
\text { Scenario }\end{array}$ \\
\hline Luxembourg & $-0.01 \%$ & $0.97 \%$ & $2.75 \%$ & $0.96 \%$ & $1.77 \%$ & $3.28 \%$ \\
\hline Austria & $0.00 \%$ & $0.34 \%$ & $1.33 \%$ & $-0.27 \%$ & $0.12 \%$ & $1.18 \%$ \\
\hline Ireland & $0.41 \%$ & $2.00 \%$ & $3.95 \%$ & $3.90 \%$ & $4.87 \%$ & $5.87 \%$ \\
\hline United States & $0.02 \%$ & $0.37 \%$ & $1.03 \%$ & $0.33 \%$ & $0.63 \%$ & $1.20 \%$ \\
\hline New Zealand & $0.12 \%$ & $0.61 \%$ & $1.46 \%$ & $0.47 \%$ & $0.89 \%$ & $1.65 \%$ \\
\hline Iceland & $0.13 \%$ & $0.95 \%$ & $1.87 \%$ & $1.13 \%$ & $1.78 \%$ & $2.42 \%$ \\
\hline Canada & $0.20 \%$ & $1.49 \%$ & $2.90 \%$ & $3.43 \%$ & $4.13 \%$ & $4.65 \%$ \\
\hline Cyprus & $0.19 \%$ & $0.95 \%$ & $1.92 \%$ & $1.38 \%$ & $1.94 \%$ & $2.58 \%$ \\
\hline Australia & $0.32 \%$ & $1.82 \%$ & $3.23 \%$ & $3.71 \%$ & $4.58 \%$ & $5.06 \%$ \\
\hline Spain & $0.03 \%$ & $0.32 \%$ & $0.81 \%$ & $0.34 \%$ & $0.57 \%$ & $0.98 \%$ \\
\hline Malta & $0.37 \%$ & $0.99 \%$ & $1.66 \%$ & $1.26 \%$ & $1.72 \%$ & $2.14 \%$ \\
\hline Sweden & $0.03 \%$ & $0.51 \%$ & $1.05 \%$ & $0.74 \%$ & $1.09 \%$ & $1.44 \%$ \\
\hline Germany & $0.01 \%$ & $0.23 \%$ & $0.57 \%$ & $0.23 \%$ & $0.41 \%$ & $0.69 \%$ \\
\hline Belgium & $0.01 \%$ & $0.43 \%$ & $0.98 \%$ & $0.78 \%$ & $1.07 \%$ & $1.41 \%$ \\
\hline Denmark & $0.01 \%$ & $0.13 \%$ & $0.38 \%$ & $0.06 \%$ & $0.17 \%$ & $0.40 \%$ \\
\hline Netherlands & $0.03 \%$ & $0.49 \%$ & $1.04 \%$ & $0.83 \%$ & $1.15 \%$ & $1.47 \%$ \\
\hline United Kingdom & $0.11 \%$ & $0.81 \%$ & $1.52 \%$ & $1.46 \%$ & $1.93 \%$ & $2.26 \%$ \\
\hline Finland & $0.01 \%$ & $0.15 \%$ & $0.39 \%$ & $0.14 \%$ & $0.25 \%$ & $0.46 \%$ \\
\hline Switzerland & $-0.03 \%$ & $0.74 \%$ & $1.48 \%$ & $1.72 \%$ & $2.17 \%$ & $2.44 \%$ \\
\hline Portugal & $0.02 \%$ & $0.15 \%$ & $0.39 \%$ & $0.17 \%$ & $0.28 \%$ & $0.47 \%$ \\
\hline Bulgaria & $0.02 \%$ & $0.16 \%$ & $0.35 \%$ & $0.23 \%$ & $0.34 \%$ & $0.47 \%$ \\
\hline Italy & $0.00 \%$ & $0.06 \%$ & $0.18 \%$ & $0.01 \%$ & $0.07 \%$ & $0.19 \%$ \\
\hline France & $0.01 \%$ & $0.28 \%$ & $0.55 \%$ & $0.50 \%$ & $0.68 \%$ & $0.82 \%$ \\
\hline Turkey & $0.04 \%$ & $0.21 \%$ & $0.40 \%$ & $0.37 \%$ & $0.48 \%$ & $0.58 \%$ \\
\hline Japan & $0.00 \%$ & $0.06 \%$ & $0.13 \%$ & $0.07 \%$ & $0.11 \%$ & $0.17 \%$ \\
\hline Czech Republic & $0.02 \%$ & $0.22 \%$ & $0.40 \%$ & $0.38 \%$ & $0.52 \%$ & $0.60 \%$ \\
\hline Slovakia & $0.01 \%$ & $0.06 \%$ & $0.13 \%$ & $0.08 \%$ & $0.12 \%$ & $0.17 \%$ \\
\hline Greece & $0.00 \%$ & $0.02 \%$ & $0.05 \%$ & $0.01 \%$ & $0.03 \%$ & $0.06 \%$ \\
\hline Chile & $0.00 \%$ & $0.01 \%$ & $0.03 \%$ & $0.02 \%$ & $0.03 \%$ & $0.04 \%$ \\
\hline Mexico & $0.01 \%$ & $0.05 \%$ & $0.10 \%$ & $0.10 \%$ & $0.13 \%$ & $0.15 \%$ \\
\hline Korea & $0.00 \%$ & $0.01 \%$ & $0.02 \%$ & $0.03 \%$ & $0.03 \%$ & $0.03 \%$ \\
\hline Romania & $0.00 \%$ & $0.01 \%$ & $0.01 \%$ & $0.02 \%$ & $0.03 \%$ & $0.02 \%$ \\
\hline Slovenia & $0.01 \%$ & $0.07 \%$ & $0.11 \%$ & $0.16 \%$ & $0.19 \%$ & $0.19 \%$ \\
\hline Hungary & $0.00 \%$ & $0.01 \%$ & $0.00 \%$ & $0.03 \%$ & $0.03 \%$ & $0.02 \%$ \\
\hline Poland & $0.00 \%$ & $-0.04 \%$ & $-0.17 \%$ & $0.02 \%$ & $-0.02 \%$ & $-0.15 \%$ \\
\hline Lithuania & $0.03 \%$ & $0.07 \%$ & $-0.14 \%$ & $0.41 \%$ & $0.38 \%$ & $0.07 \%$ \\
\hline Latvia & $-0.05 \%$ & $-0.98 \%$ & $-2.91 \%$ & $-0.32 \%$ & $-1.19 \%$ & $-3.06 \%$ \\
\hline Estonia & $-0.65 \%$ & $-2.14 \%$ & $-4.48 \%$ & $-1.33 \%$ & $-2.69 \%$ & $-4.84 \%$ \\
\hline Israel & $-4.80 \%$ & $1.39 \%$ & $8.03 \%$ & $12.99 \%$ & $15.85 \%$ & $17.56 \%$ \\
\hline
\end{tabular}


Table A5: Simulated employment effects of immigration on less educated and all natives

\begin{tabular}{|c|c|c|c|c|c|c|}
\hline \multirow[b]{2}{*}{ Country } & \multicolumn{3}{|c|}{ Average wage effects on natives } & \multicolumn{3}{|c|}{ Wage effect on Less educated Natives } \\
\hline & $\begin{array}{c}\text { Pessimistic } \\
\text { Scenario }\end{array}$ & $\begin{array}{l}\text { Intermediate } \\
\text { Scenario }\end{array}$ & $\begin{array}{l}\text { Optimistic } \\
\text { Scenario }\end{array}$ & $\begin{array}{c}\text { Pessimistic } \\
\text { Scenario }\end{array}$ & $\begin{array}{l}\text { Intermediate } \\
\text { Scenario }\end{array}$ & $\begin{array}{c}\text { Optimistic } \\
\text { Scenario }\end{array}$ \\
\hline Luxembourg & $0.04 \%$ & $0.11 \%$ & $0.00 \%$ & $0.19 \%$ & $0.18 \%$ & $0.00 \%$ \\
\hline Austria & $-0.01 \%$ & $0.03 \%$ & $0.00 \%$ & $-0.05 \%$ & $0.01 \%$ & $0.00 \%$ \\
\hline Ireland & $0.34 \%$ & $0.30 \%$ & $0.00 \%$ & $0.78 \%$ & $0.49 \%$ & $0.00 \%$ \\
\hline United States & $0.01 \%$ & $0.04 \%$ & $0.00 \%$ & $0.07 \%$ & $0.06 \%$ & $0.00 \%$ \\
\hline New Zealand & $0.04 \%$ & $0.07 \%$ & $0.00 \%$ & $0.09 \%$ & $0.09 \%$ & $0.00 \%$ \\
\hline Iceland & $0.07 \%$ & $0.11 \%$ & $0.00 \%$ & $0.23 \%$ & $0.18 \%$ & $0.00 \%$ \\
\hline Canada & $0.11 \%$ & $0.18 \%$ & $0.00 \%$ & $0.69 \%$ & $0.41 \%$ & $0.00 \%$ \\
\hline Cyprus & $0.09 \%$ & $0.12 \%$ & $0.00 \%$ & $0.28 \%$ & $0.19 \%$ & $0.00 \%$ \\
\hline Australia & $0.18 \%$ & $0.23 \%$ & $0.00 \%$ & $0.74 \%$ & $0.46 \%$ & $0.00 \%$ \\
\hline Spain & $0.03 \%$ & $0.04 \%$ & $0.00 \%$ & $0.07 \%$ & $0.06 \%$ & $0.00 \%$ \\
\hline Malta & $0.13 \%$ & $0.12 \%$ & $0.00 \%$ & $0.25 \%$ & $0.17 \%$ & $0.00 \%$ \\
\hline Sweden & $0.03 \%$ & $0.06 \%$ & $0.00 \%$ & $0.15 \%$ & $0.11 \%$ & $0.00 \%$ \\
\hline Germany & $0.01 \%$ & $0.03 \%$ & $0.00 \%$ & $0.05 \%$ & $0.04 \%$ & $0.00 \%$ \\
\hline Belgium & $0.04 \%$ & $0.06 \%$ & $0.00 \%$ & $0.16 \%$ & $0.11 \%$ & $0.00 \%$ \\
\hline Denmark & $0.00 \%$ & $0.01 \%$ & $0.00 \%$ & $0.01 \%$ & $0.02 \%$ & $0.00 \%$ \\
\hline Netherlands & $0.04 \%$ & $0.06 \%$ & $0.00 \%$ & $0.17 \%$ & $0.11 \%$ & $0.00 \%$ \\
\hline United Kingdom & $0.11 \%$ & $0.12 \%$ & $0.00 \%$ & $0.29 \%$ & $0.19 \%$ & $0.00 \%$ \\
\hline Finland & $0.01 \%$ & $0.02 \%$ & $0.00 \%$ & $0.03 \%$ & $0.02 \%$ & $0.00 \%$ \\
\hline Switzerland & $0.09 \%$ & $0.11 \%$ & $0.00 \%$ & $0.34 \%$ & $0.22 \%$ & $0.00 \%$ \\
\hline Portugal & $0.02 \%$ & $0.02 \%$ & $0.00 \%$ & $0.03 \%$ & $0.03 \%$ & $0.00 \%$ \\
\hline Bulgaria & $0.02 \%$ & $0.02 \%$ & $0.00 \%$ & $0.05 \%$ & $0.03 \%$ & $0.00 \%$ \\
\hline Italy & $0.00 \%$ & $0.01 \%$ & $0.00 \%$ & $0.00 \%$ & $0.01 \%$ & $0.00 \%$ \\
\hline France & $0.02 \%$ & $0.04 \%$ & $0.00 \%$ & $0.10 \%$ & $0.07 \%$ & $0.00 \%$ \\
\hline Turkey & $0.03 \%$ & $0.03 \%$ & $0.00 \%$ & $0.07 \%$ & $0.05 \%$ & $0.00 \%$ \\
\hline Japan & $0.00 \%$ & $0.01 \%$ & $0.00 \%$ & $0.01 \%$ & $0.01 \%$ & $0.00 \%$ \\
\hline Czech Republic & $0.02 \%$ & $0.03 \%$ & $0.00 \%$ & $0.08 \%$ & $0.05 \%$ & $0.00 \%$ \\
\hline Slovakia & $0.01 \%$ & $0.01 \%$ & $0.00 \%$ & $0.02 \%$ & $0.01 \%$ & $0.00 \%$ \\
\hline Greece & $0.00 \%$ & $0.00 \%$ & $0.00 \%$ & $0.00 \%$ & $0.00 \%$ & $0.00 \%$ \\
\hline Chile & $0.00 \%$ & $0.00 \%$ & $0.00 \%$ & $0.00 \%$ & $0.00 \%$ & $0.00 \%$ \\
\hline Mexico & $0.01 \%$ & $0.01 \%$ & $0.00 \%$ & $0.02 \%$ & $0.01 \%$ & $0.00 \%$ \\
\hline Korea & $0.00 \%$ & $0.00 \%$ & $0.00 \%$ & $0.01 \%$ & $0.00 \%$ & $0.00 \%$ \\
\hline Romania & $0.00 \%$ & $0.00 \%$ & $0.00 \%$ & $0.00 \%$ & $0.00 \%$ & $0.00 \%$ \\
\hline Slovenia & $0.01 \%$ & $0.01 \%$ & $0.00 \%$ & $0.03 \%$ & $0.02 \%$ & $0.00 \%$ \\
\hline Hungary & $0.00 \%$ & $0.00 \%$ & $0.00 \%$ & $0.01 \%$ & $0.00 \%$ & $0.00 \%$ \\
\hline Poland & $0.00 \%$ & $0.00 \%$ & $0.00 \%$ & $0.00 \%$ & $0.00 \%$ & $0.00 \%$ \\
\hline Lithuania & $0.03 \%$ & $0.02 \%$ & $0.00 \%$ & $0.08 \%$ & $0.04 \%$ & $0.00 \%$ \\
\hline Latvia & $-0.02 \%$ & $-0.10 \%$ & $0.00 \%$ & $-0.06 \%$ & $-0.12 \%$ & $0.00 \%$ \\
\hline Estonia & $-0.17 \%$ & $-0.23 \%$ & $0.00 \%$ & $-0.27 \%$ & $-0.27 \%$ & $0.00 \%$ \\
\hline Israel & $-0.25 \%$ & $0.43 \%$ & $0.00 \%$ & $2.60 \%$ & $1.59 \%$ & $0.00 \%$ \\
\hline
\end{tabular}


Table A6: Simulated Wage Effects of Emigration

\begin{tabular}{|c|c|c|c|c|c|c|}
\hline \multirow{2}{*}{ Country } & \multicolumn{3}{|c|}{ Effect on Wages of Less Educated Natives } & \multicolumn{3}{|c|}{ Effect on Average Wages of Natives } \\
\hline & $\begin{array}{c}\text { Pessimistic } \\
\text { Scenario }\end{array}$ & $\begin{array}{l}\text { Intermediate } \\
\text { Scenario }\end{array}$ & $\begin{array}{c}\text { Optimistic } \\
\text { Scenario }\end{array}$ & $\begin{array}{l}\text { Pessimistic } \\
\text { Scenario }\end{array}$ & $\begin{array}{c}\text { Intermediate } \\
\text { Scenario }\end{array}$ & $\begin{array}{c}\text { Optimistic } \\
\text { Scenario }\end{array}$ \\
\hline Cyprus & $-6.81 \%$ & $-5.93 \%$ & $-4.54 \%$ & $-3.52 \%$ & $-2.30 \%$ & $-0.37 \%$ \\
\hline Malta & $-3.47 \%$ & $-3.03 \%$ & $-2.35 \%$ & $-2.00 \%$ & $-1.50 \%$ & $-0.62 \%$ \\
\hline Ireland & $-6.59 \%$ & $-5.90 \%$ & $-4.84 \%$ & $-3.01 \%$ & $-1.92 \%$ & $-0.25 \%$ \\
\hline Mexico & $-1.29 \%$ & $-1.13 \%$ & $-0.87 \%$ & $-0.63 \%$ & $-0.39 \%$ & $-0.01 \%$ \\
\hline New Zealand & $-3.99 \%$ & $-3.47 \%$ & $-2.60 \%$ & $-2.11 \%$ & $-1.65 \%$ & $-0.61 \%$ \\
\hline Portugal & $-1.50 \%$ & $-1.35 \%$ & $-1.11 \%$ & $-0.68 \%$ & $-0.41 \%$ & $-0.01 \%$ \\
\hline Estonia & $-1.56 \%$ & $-1.45 \%$ & $-1.15 \%$ & $-0.73 \%$ & $-0.84 \%$ & $-0.57 \%$ \\
\hline Romania & $-0.92 \%$ & $-0.80 \%$ & $-0.62 \%$ & $-0.46 \%$ & $-0.28 \%$ & $-0.01 \%$ \\
\hline Latvia & $-1.54 \%$ & $-1.36 \%$ & $-1.05 \%$ & $-0.65 \%$ & $-0.51 \%$ & $-0.12 \%$ \\
\hline Slovenia & $-0.74 \%$ & $-0.71 \%$ & $-0.58 \%$ & $-0.29 \%$ & $-0.21 \%$ & $0.00 \%$ \\
\hline Slovakia & $-1.09 \%$ & $-0.95 \%$ & $-0.72 \%$ & $-0.55 \%$ & $-0.33 \%$ & $0.00 \%$ \\
\hline Poland & $-1.10 \%$ & $-0.97 \%$ & $-0.77 \%$ & $-0.53 \%$ & $-0.32 \%$ & $-0.01 \%$ \\
\hline Korea & $-1.62 \%$ & $-1.44 \%$ & $-1.15 \%$ & $-0.76 \%$ & $-0.46 \%$ & $-0.01 \%$ \\
\hline Lithuania & $-1.32 \%$ & $-1.15 \%$ & $-0.88 \%$ & $-0.64 \%$ & $-0.40 \%$ & $-0.02 \%$ \\
\hline $\begin{array}{l}\text { Bulgaria } \\
\text { United }\end{array}$ & $-1.13 \%$ & $-1.00 \%$ & $-0.78 \%$ & $-0.54 \%$ & $-0.33 \%$ & $0.00 \%$ \\
\hline Kingdom & $-1.59 \%$ & $-1.42 \%$ & $-1.15 \%$ & $-0.72 \%$ & $-0.44 \%$ & $-0.02 \%$ \\
\hline Iceland & $-0.74 \%$ & $-0.66 \%$ & $-0.51 \%$ & $-0.36 \%$ & $-0.24 \%$ & $-0.03 \%$ \\
\hline Turkey & $-0.25 \%$ & $-0.22 \%$ & $-0.18 \%$ & $-0.11 \%$ & $-0.07 \%$ & $0.00 \%$ \\
\hline Greece & $-0.73 \%$ & $-0.64 \%$ & $-0.50 \%$ & $-0.36 \%$ & $-0.22 \%$ & $-0.01 \%$ \\
\hline Chile & $-0.53 \%$ & $-0.46 \%$ & $-0.35 \%$ & $-0.26 \%$ & $-0.16 \%$ & $0.00 \%$ \\
\hline Luxembourg & $-1.23 \%$ & $-1.06 \%$ & $-0.82 \%$ & $-0.51 \%$ & $-0.29 \%$ & $0.06 \%$ \\
\hline Switzerland & $-0.61 \%$ & $-0.58 \%$ & $-0.48 \%$ & $-0.21 \%$ & $-0.14 \%$ & $0.03 \%$ \\
\hline Finland & $-0.96 \%$ & $-0.85 \%$ & $-0.68 \%$ & $-0.44 \%$ & $-0.27 \%$ & $0.00 \%$ \\
\hline Netherlands & $-0.72 \%$ & $-0.63 \%$ & $-0.48 \%$ & $-0.33 \%$ & $-0.20 \%$ & $0.01 \%$ \\
\hline Spain & $-0.53 \%$ & $-0.47 \%$ & $-0.38 \%$ & $-0.25 \%$ & $-0.15 \%$ & $0.00 \%$ \\
\hline Belgium & $-0.90 \%$ & $-0.79 \%$ & $-0.63 \%$ & $-0.39 \%$ & $-0.22 \%$ & $0.03 \%$ \\
\hline Sweden & $-0.53 \%$ & $-0.46 \%$ & $-0.36 \%$ & $-0.25 \%$ & $-0.15 \%$ & $0.01 \%$ \\
\hline Denmark & $-0.57 \%$ & $-0.50 \%$ & $-0.38 \%$ & $-0.28 \%$ & $-0.17 \%$ & $0.00 \%$ \\
\hline Austria & $-0.50 \%$ & $-0.44 \%$ & $-0.34 \%$ & $-0.23 \%$ & $-0.13 \%$ & $0.01 \%$ \\
\hline Australia & $-0.44 \%$ & $-0.40 \%$ & $-0.32 \%$ & $-0.17 \%$ & $-0.13 \%$ & $-0.02 \%$ \\
\hline Canada & $-1.18 \%$ & $-1.04 \%$ & $-0.86 \%$ & $-0.50 \%$ & $-0.32 \%$ & $-0.04 \%$ \\
\hline Italy & $-0.42 \%$ & $-0.36 \%$ & $-0.28 \%$ & $-0.21 \%$ & $-0.12 \%$ & $0.00 \%$ \\
\hline Czech & & & $-006 \%$ & - $04 \% \%$ & $-0.03 \%$ & $0.00 \%$ \\
\hline Germany & $\begin{array}{l}-0.09 \% \\
-0.40 \%\end{array}$ & $\begin{array}{l}-0.08 \% \\
-0.35 \%\end{array}$ & $\begin{array}{l}-0.06 \% \\
-0.27 \%\end{array}$ & $-0.19 \%$ & $-0.11 \%$ & $0.00 \%$ \\
\hline France & $-0.31 \%$ & $-0.28 \%$ & $-0.22 \%$ & $-0.14 \%$ & $-0.08 \%$ & $0.01 \%$ \\
\hline Hungary & $-0.05 \%$ & $-0.05 \%$ & $-0.04 \%$ & $-0.02 \%$ & $-0.01 \%$ & $0.00 \%$ \\
\hline Japan & $-0.10 \%$ & $-0.09 \%$ & $-0.07 \%$ & $-0.05 \%$ & $-0.03 \%$ & $0.00 \%$ \\
\hline United States & $-0.10 \%$ & $-0.09 \%$ & $-0.08 \%$ & $-0.04 \%$ & $-0.02 \%$ & $0.00 \%$ \\
\hline Israel & $1.42 \%$ & $0.51 \%$ & $0.11 \%$ & $0.86 \%$ & $0.25 \%$ & $-0.04 \%$ \\
\hline
\end{tabular}


Table A7: Estimates of Share of undocumented immigrants, by country as of $\mathbf{2 0 0 0}$

\begin{tabular}{|c|c|c|c|}
\hline \multirow[b]{2}{*}{ Country } & \multicolumn{3}{|c|}{ Estimated undocumented as share of total immigrants } \\
\hline & Lower bound & Upper bound & Source of the estimates \\
\hline Australia & $\mathbf{0}$ & 0 & Census includes undocumented \\
\hline Austria & 0.03 & 0.09 & From Clandestino \\
\hline Belgium & 0.03 & 0.06 & as Germany \\
\hline Bulgaria & 0.06 & 0.37 & as Poland \\
\hline Canada & 0.00 & 0.00 & Census includes undocumented \\
\hline Cyprus & 0.17 & 0.23 & as Greece \\
\hline Czech Republic & 0.30 & 0.30 & from Clandestino \\
\hline Denmark & 0.04 & 0.09 & as Netherlands \\
\hline Estonia & 0.04 & 0.09 & as Netherlands \\
\hline Finland & 0.04 & 0.09 & as Netherlands \\
\hline France & 0.04 & 0.08 & from Clandestino \\
\hline Germany & 0.03 & 0.06 & from Clandestino \\
\hline Greece & 0.17 & 0.23 & from Clandestino \\
\hline Hungary & 0.09 & 0.14 & from Clandestino \\
\hline Ireland & 0.06 & 0.10 & as UK \\
\hline Italy & 0.27 & 0.33 & from Clandestino \\
\hline Latvia & 0.04 & 0.09 & as Netherlands \\
\hline Lithuania & 0.04 & 0.09 & as Netherlands \\
\hline Luxembourg & 0.03 & 0.06 & as Germany \\
\hline Malta & 0.17 & 0.23 & as Greece \\
\hline Netherlands & 0.04 & 0.09 & from Clandestino \\
\hline New Zealand & 0.00 & 0.00 & Census includes undocumented \\
\hline Poland & 0.06 & 0.37 & from Clandestino \\
\hline Portugal & 0.09 & 0.09 & as Spain \\
\hline Romania & 0.06 & 0.37 & as Poland \\
\hline Slovakia & 0.12 & 0.22 & from Clandestino \\
\hline Slovenia & 0.03 & 0.09 & as Austria \\
\hline Spain & 0.09 & 0.09 & from Clandestino \\
\hline Sweden & 0.04 & 0.09 & as Netherlands \\
\hline United Kingdom & 0.06 & 0.10 & from Clandestino \\
\hline United States & 0.00 & 0.10 & Census includes undocumented, but possibly undercounted \\
\hline Chile & 0.07 & 0.14 & set to the average for lack of information \\
\hline Iceland & 0.04 & 0.09 & as Netherlands \\
\hline Israel & 0.17 & 0.23 & as Greece \\
\hline Japan & 0.07 & 0.14 & set to the average for lack of information \\
\hline Korea & 0.07 & 0.14 & set to the average for lack of information \\
\hline Mexico & 0.00 & 0.10 & census includes undocumented, but possibly undercounted \\
\hline Switzerland & 0.03 & 0.09 & as Austria \\
\hline Turkey & 0.17 & 0.23 & as Greece \\
\hline
\end{tabular}

Note: the source "Clandestino" is European Union (2009). The other countries are given the estimates relative to a neighbor. 
Table A8: Estimates of The downgrading factors, based on occupations, for highly educated immigrants, by country, as of 2000

\begin{tabular}{|c|c|c|}
\hline Country & $\begin{array}{l}\text { Share of college educated } \\
\text { immigrants to be counted as } \\
\text { college educated natives }(\tau)\end{array}$ & $\begin{array}{c}\text { Share of college educated } \\
\text { immigrants to be counted as less } \\
\text { educated natives }(1-\tau)\end{array}$ \\
\hline Australia & 0.86 & 0.14 \\
\hline Austria & 0.93 & 0.07 \\
\hline Belgium & 0.95 & 0.05 \\
\hline Bulgaria & 0.88 & 0.12 \\
\hline Canada & 0.95 & 0.05 \\
\hline Chile & 0.55 & 0.45 \\
\hline Cyprus & 0.60 & 0.40 \\
\hline Denmark & 0.65 & 0.35 \\
\hline Estonia & 0.65 & 0.35 \\
\hline Finland & 0.83 & 0.17 \\
\hline France & 0.97 & 0.03 \\
\hline Germany & 0.88 & 0.12 \\
\hline Greece & 0.60 & 0.40 \\
\hline Hungary & 0.95 & 0.05 \\
\hline Ireland & 0.98 & 0.02 \\
\hline Israel & 0.58 & 0.42 \\
\hline Italy & 0.85 & 0.15 \\
\hline Latvia & 0.79 & 0.21 \\
\hline Lithuania & 0.74 & 0.26 \\
\hline Luxembourg & 0.94 & 0.06 \\
\hline Malta & 0.85 & 0.15 \\
\hline Mexico & 1.40 & -0.40 \\
\hline Netherlands & 0.84 & 0.16 \\
\hline New Zealand & 1.17 & -0.17 \\
\hline Poland & 1.02 & -0.02 \\
\hline Portugal & 0.91 & 0.09 \\
\hline Romania & 1.10 & -0.10 \\
\hline Slovakia & 0.80 & 0.20 \\
\hline Slovenia & 0.84 & 0.16 \\
\hline Spain & 0.85 & 0.15 \\
\hline Sweden & 0.66 & 0.34 \\
\hline Switzerland & 0.89 & 0.11 \\
\hline United Kingdom & 0.96 & 0.04 \\
\hline United States & 0.95 & 0.05 \\
\hline
\end{tabular}

